\title{
Manufatcuring Process Development for Belzutifan, Part 4: Nitrogen Flow Criticality for Transfer Hydrogenation Control
}

Nastaran Salehi Marzijarani, Adam J. Fine, Stephen M. Dalby, Rekha Gangam, Samiksha Poudyal, Taylor Behre, Anil R. Ekkati, Brittany M. Armstrong, C. Scott Shultz, Zachary E. X. Dance, Kevin Stone

\section{Table of Contents}

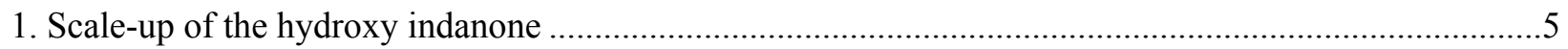

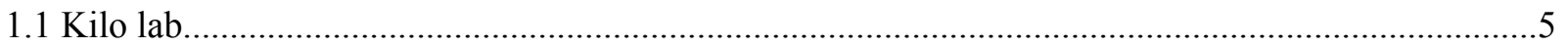

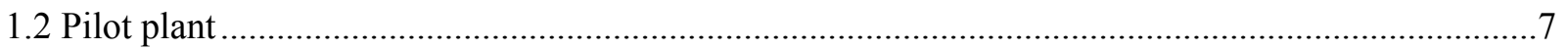

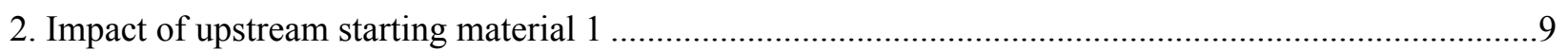

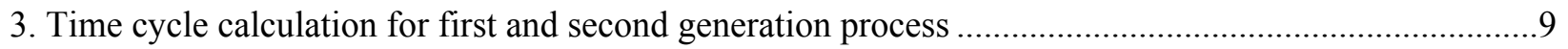

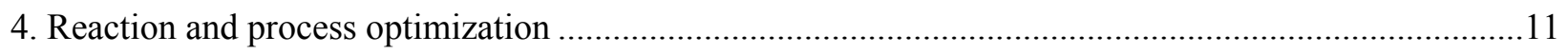

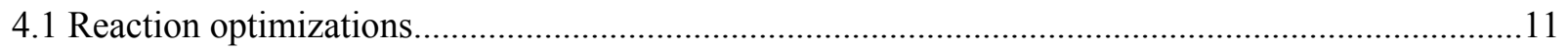

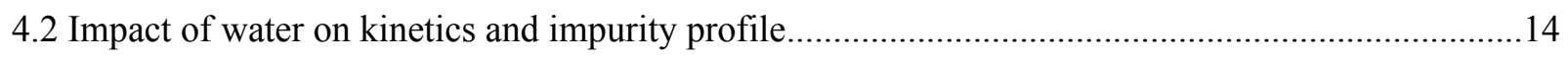

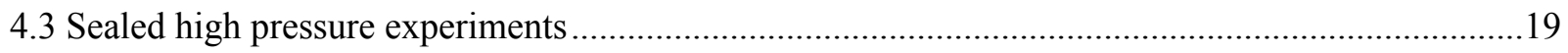

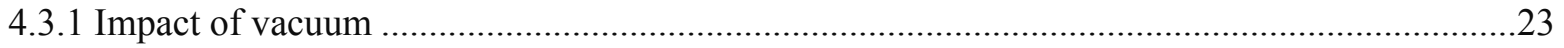

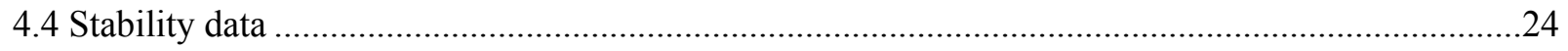

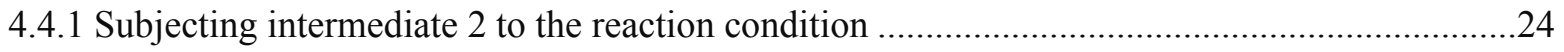

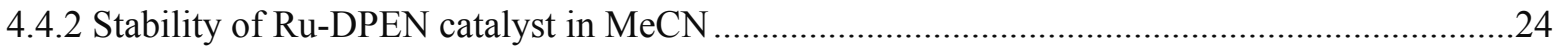

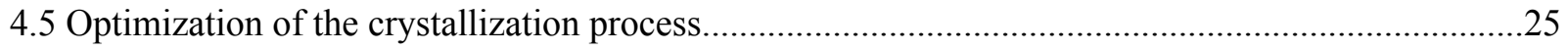

4.6 Impact of water additive on the quality of isolated solid ............................................................30

4.7 Scale and equipment dependency of the reduction-deprotection step ............................................30

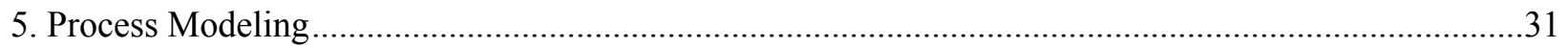

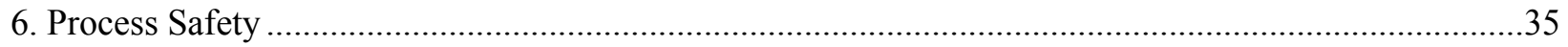

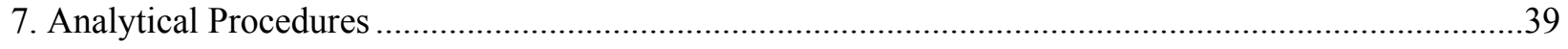

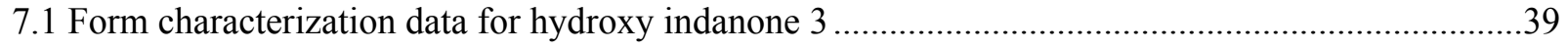

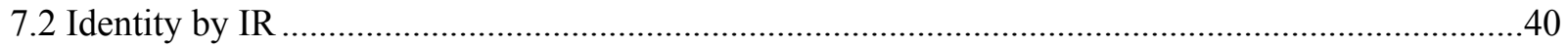

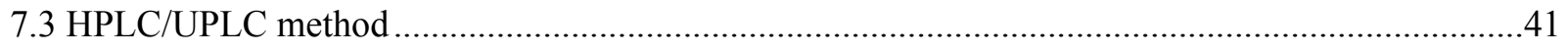




\section{List of Figures:}

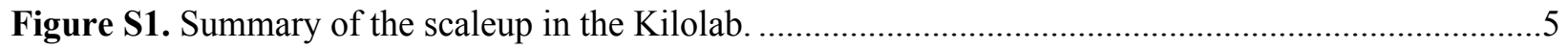

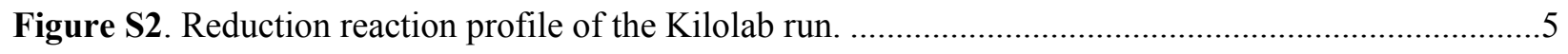

Figure S3. Crystallinity of the isolated solid $\mathbf{3}$ from the Kilolab run.......................................................

Figure S4. PAT (IR) monitoring and trends for the reaction profiles..................................................

Figure S5. Overlay of lab scale front run data with pilot scale data both using $0.0175 \mathrm{Nm} / \mathrm{h} / \mathrm{kg}$ nitrogen

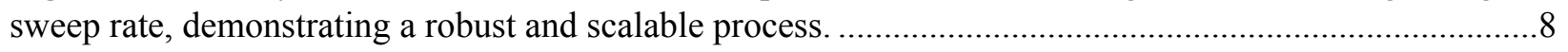

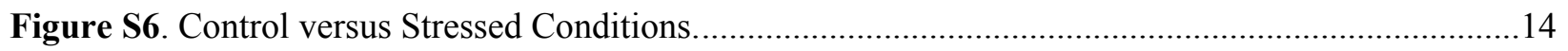

Figure S7. Impact of water additive on reaction rate for control condition..........................................15

Figure S8. Impact of water on the reaction rate for control and stressed conditions..............................15

Figure S9. Impact of water on dimer impurity for control and stressed conditions. ................................16

Figure S10. Impact of water on amine impurity for control and stressed conditions...............................16

Figure S11. Impact of water on alcohol impurity for control and stressed conditions.............................17

Figure S12. Impact of water on aldehyde impurity for control and stressed conditions. ..........................17

Figure S13. Impact of water on aldehyde plus alcohol impurity for control and stressed conditions........18

Figure S14. Temperature and pressure profile of the sealed experiment \#1 ............................................20

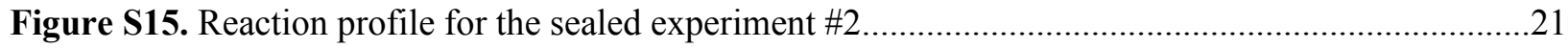

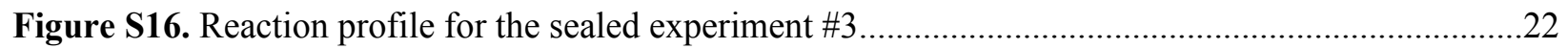

Figure S17. Temperature and pressure profile for the sealed experiment \#3 ........................................22

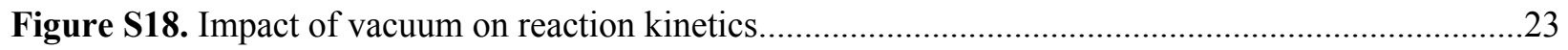

Figure S19. Comparing IPA and water as antisolvents (top) and using water antisolvent at different temperatures (bottom) for the crystallization process........................................................................25

Figure S20. Seeding regime for the crystallization process at different reaction volumes.......................26

Figure S21. Process modeling of the kLa values for the vapor-liquid mixture. ......................................33

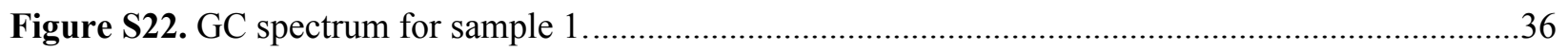

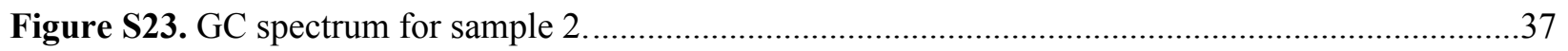

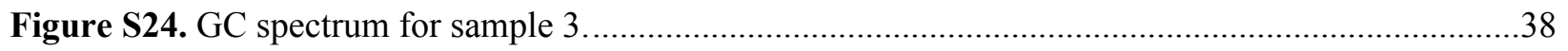

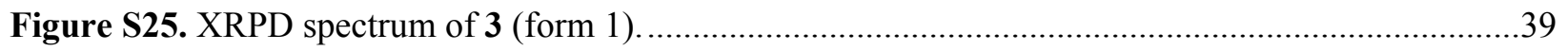

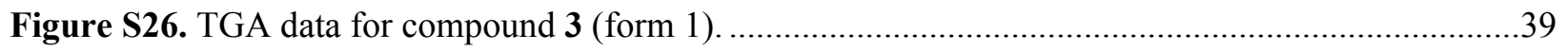

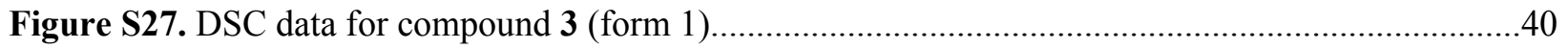




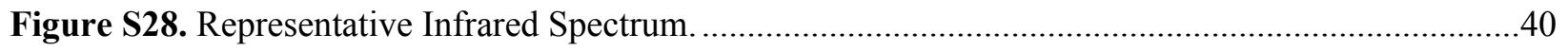

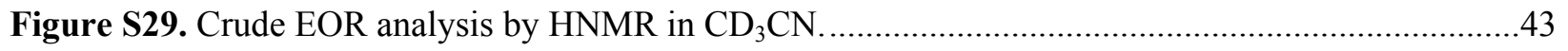

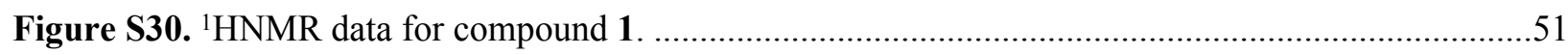

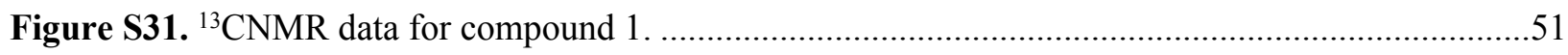

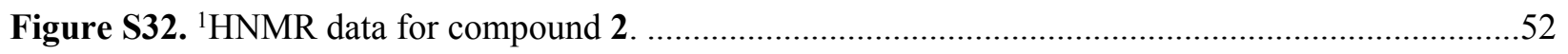

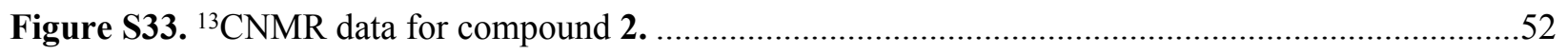

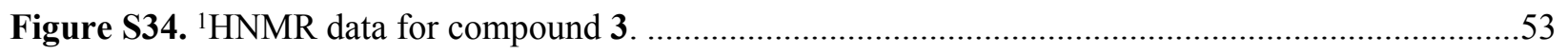

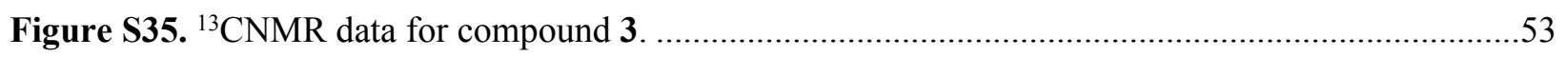

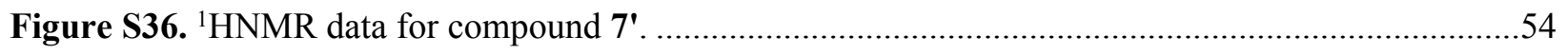

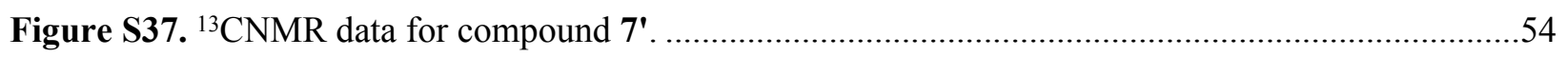

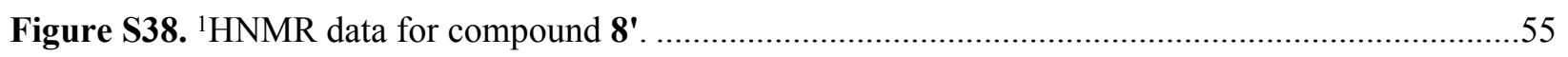

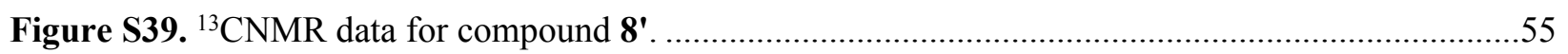

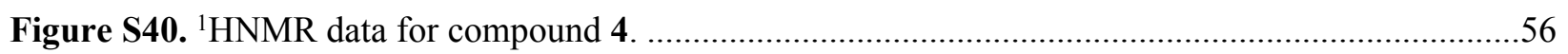

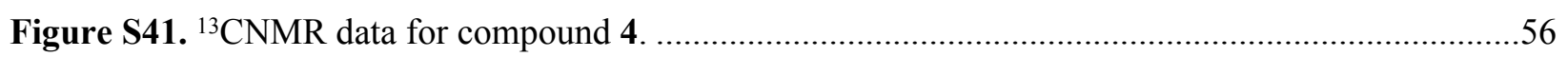

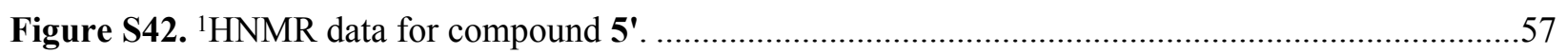

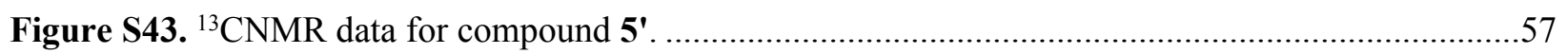

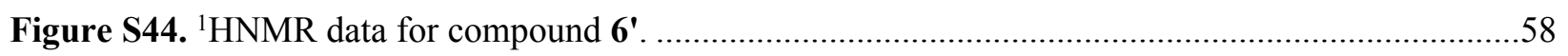

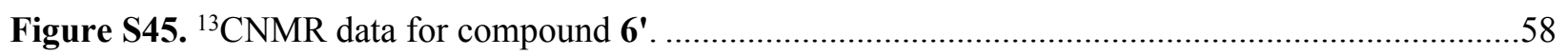

\section{List of Tables:}

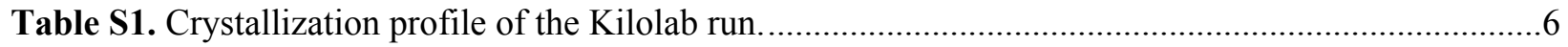

Table S2. Key data obtained from samples taken at multiple time points during the reduction reaction at pilot plant.

Table S3. Key data obtained from samples taken at multiple time points during the deprotection reaction at pilot plant.

Table S4. Time cycle calculations for first generation (A) versus final commerical process (B)............10

Table S5. Initial solvent screening for the reduction reaction..............................................................11

Table S6. Solvent screening for the reduction reaction under stressed condition....................................12

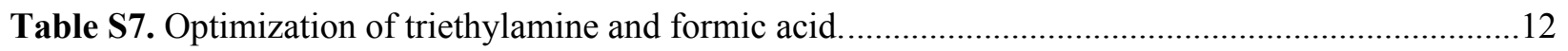

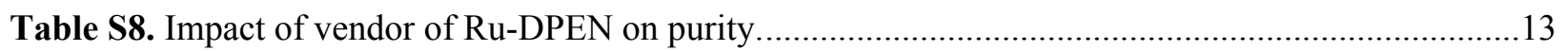

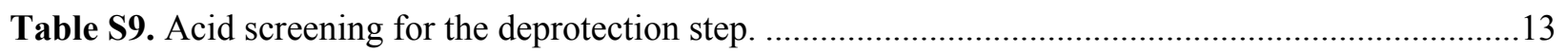

Table S10. Impact of water additive on the quality of isolated solid $\mathbf{3}$ under stressed deprotection/crystallization conditions. 


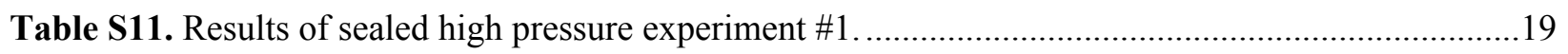

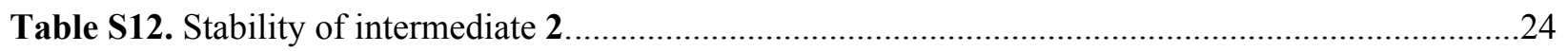

Table S13. Solubility data for compound $\mathbf{1}$ in different solvents.......................................................27

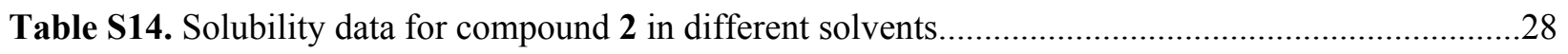

Table S15. Solubility data for compound 3 in different solvents........................................................29

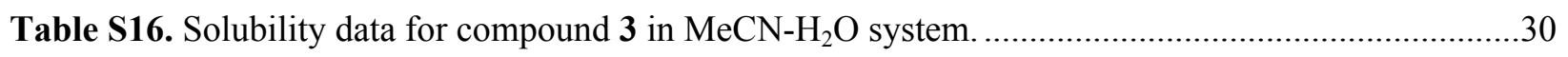

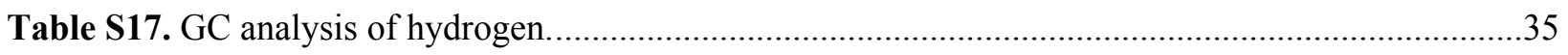

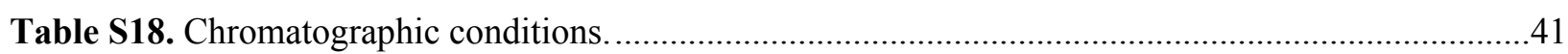

Table S19. Chromatographic conditions for chiral purity by UPLC . ....................................................41

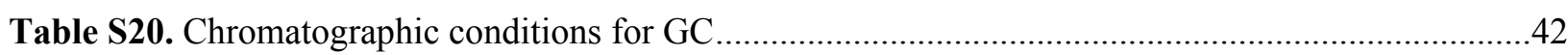

Table S21. Chromatographic conditions for IC for measuring the chloride content. ...............................42 


\section{Scale-up of the hydroxy indanone}

\subsection{Kilo lab}
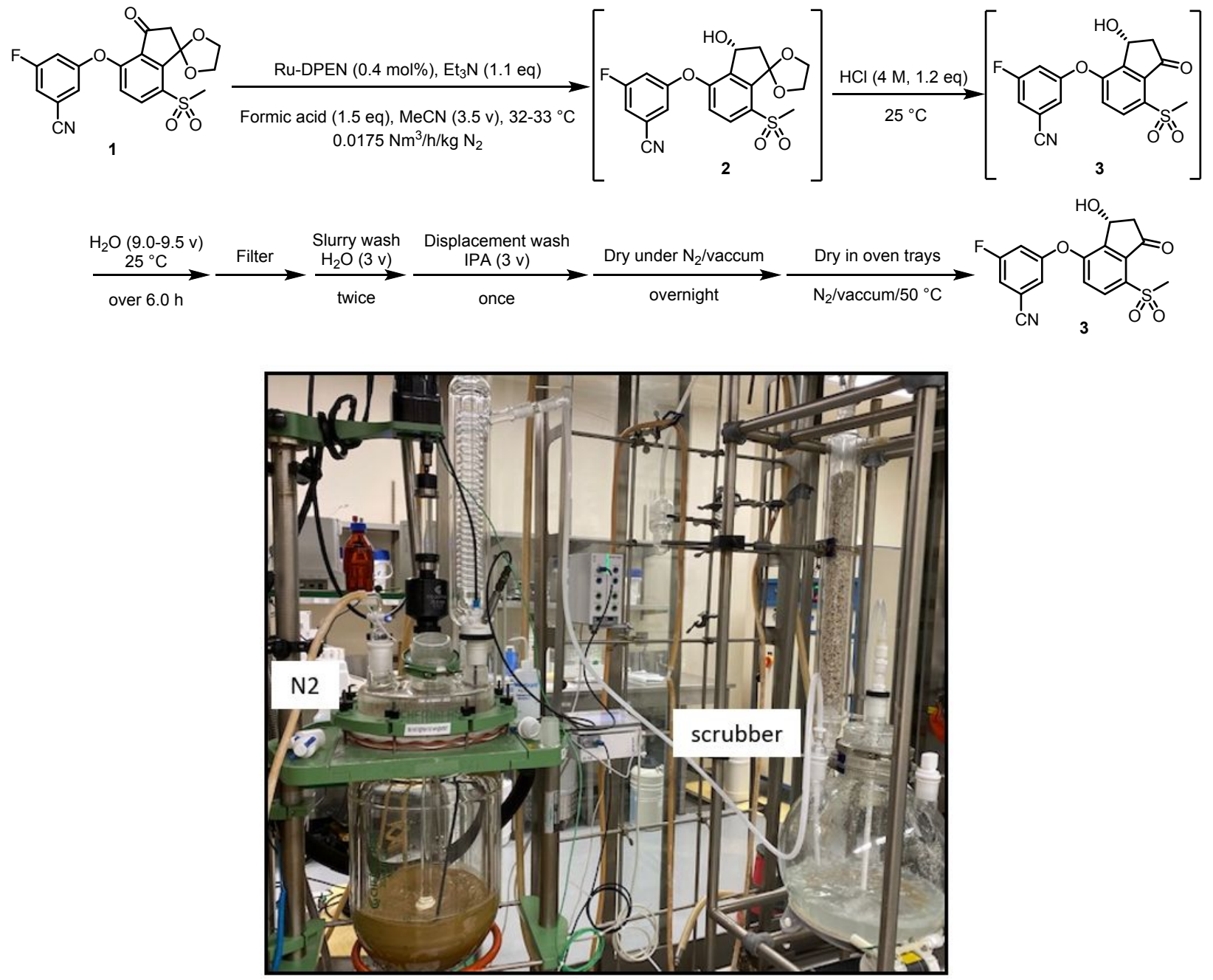

Figure S1. Summary of the scaleup in the Kilolab.

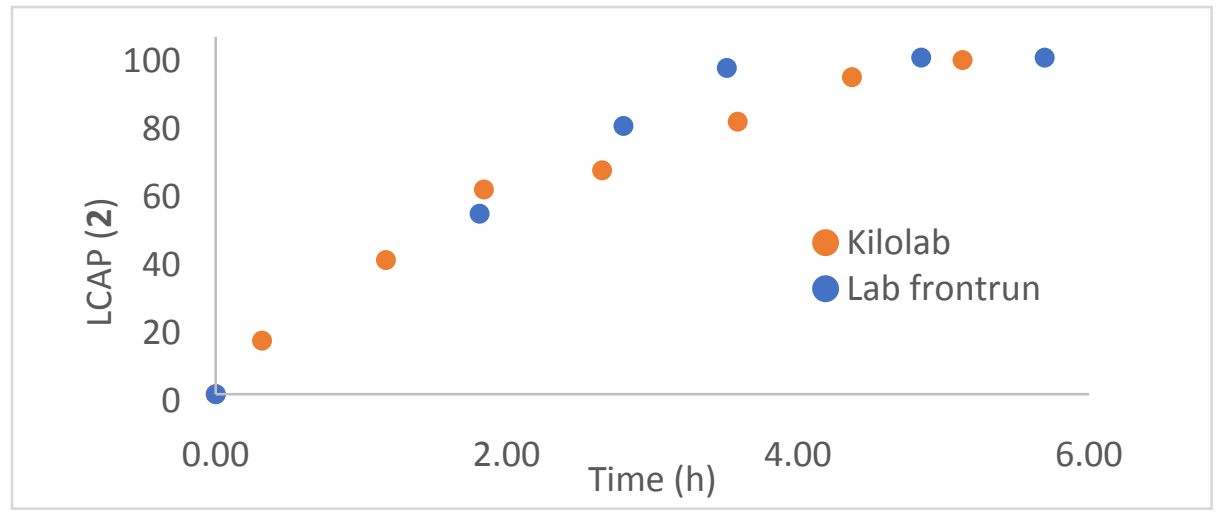

Figure S2. Reduction reaction profile of the Kilolab run. 
Table S1. Crystallization profile of the Kilolab run.

\begin{tabular}{cccc}
\hline Time (h) & {$[3] \mathbf{~ m g} / \mathbf{m L}$} & $\mathbf{H}_{\mathbf{2}} \mathbf{O}$ added & mixture \\
\hline 0.00 & 153.7 & 0 & solution \\
1.82 & 57.0 & $4.4 \mathrm{~L}(\sim 2.5 \mathrm{vol})$ & just turned slurry \\
2.39 & 21.9 & $6.9 \mathrm{~L}$ & slurry \\
3.24 & 16.5 & $9.2 \mathrm{~L}$ & slurry \\
4.51 & 6.83 & $12.9 \mathrm{~L}$ & slurry \\
5.02 & 5.95 & $14.4 \mathrm{~L}$ & slurry \\
5.45 & 5.89 & $15.3 \mathrm{~L}$ & slurry \\
6.23 & 5.46 & - & slurry \\
6.98 & 5.22 & - & slurry \\
7.92 & 5.18 & - & slurry \\
\hline
\end{tabular}
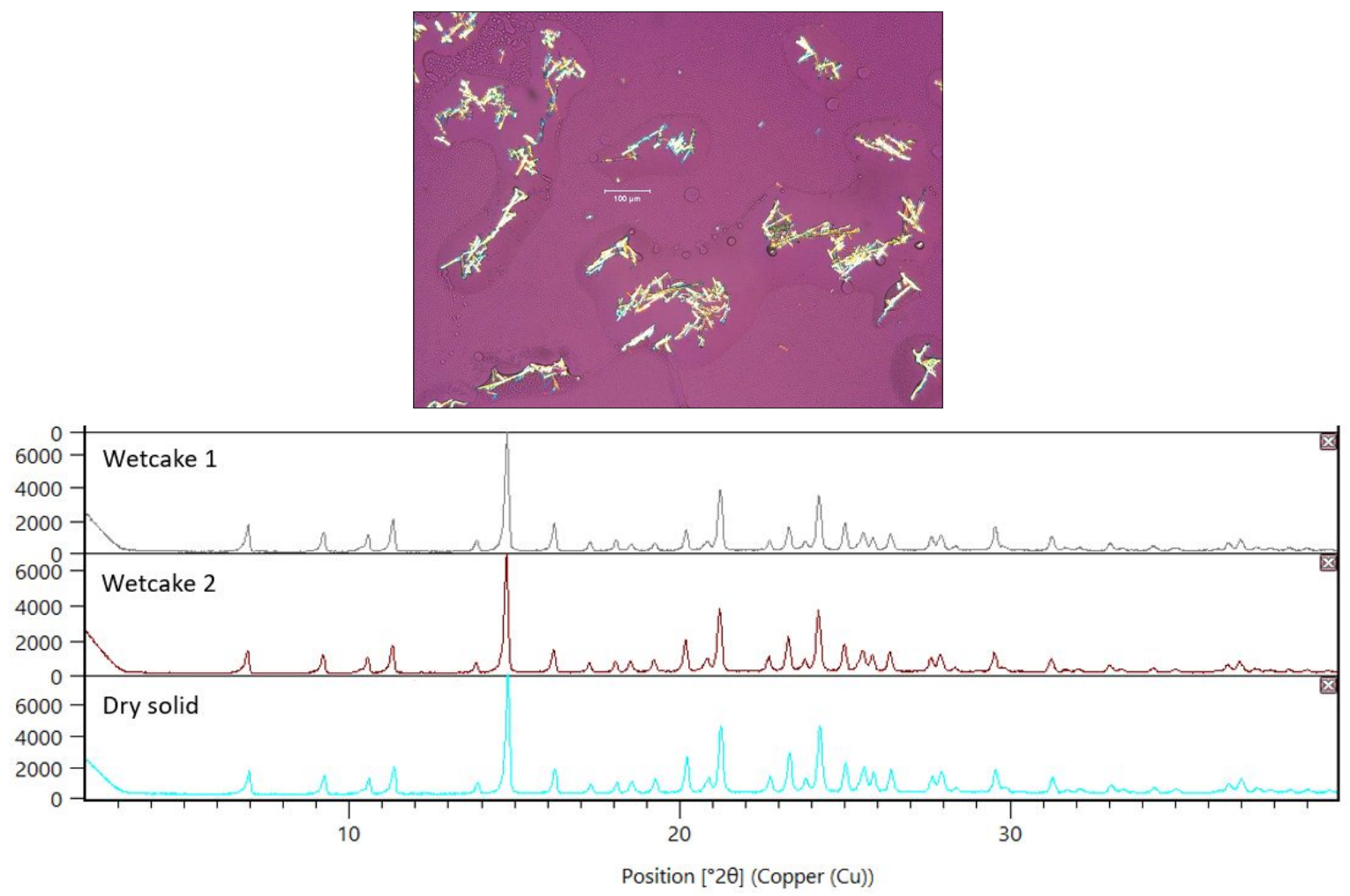

Figure S3. Crystallinity of the isolated solid $\mathbf{3}$ from the Kilolab run. 


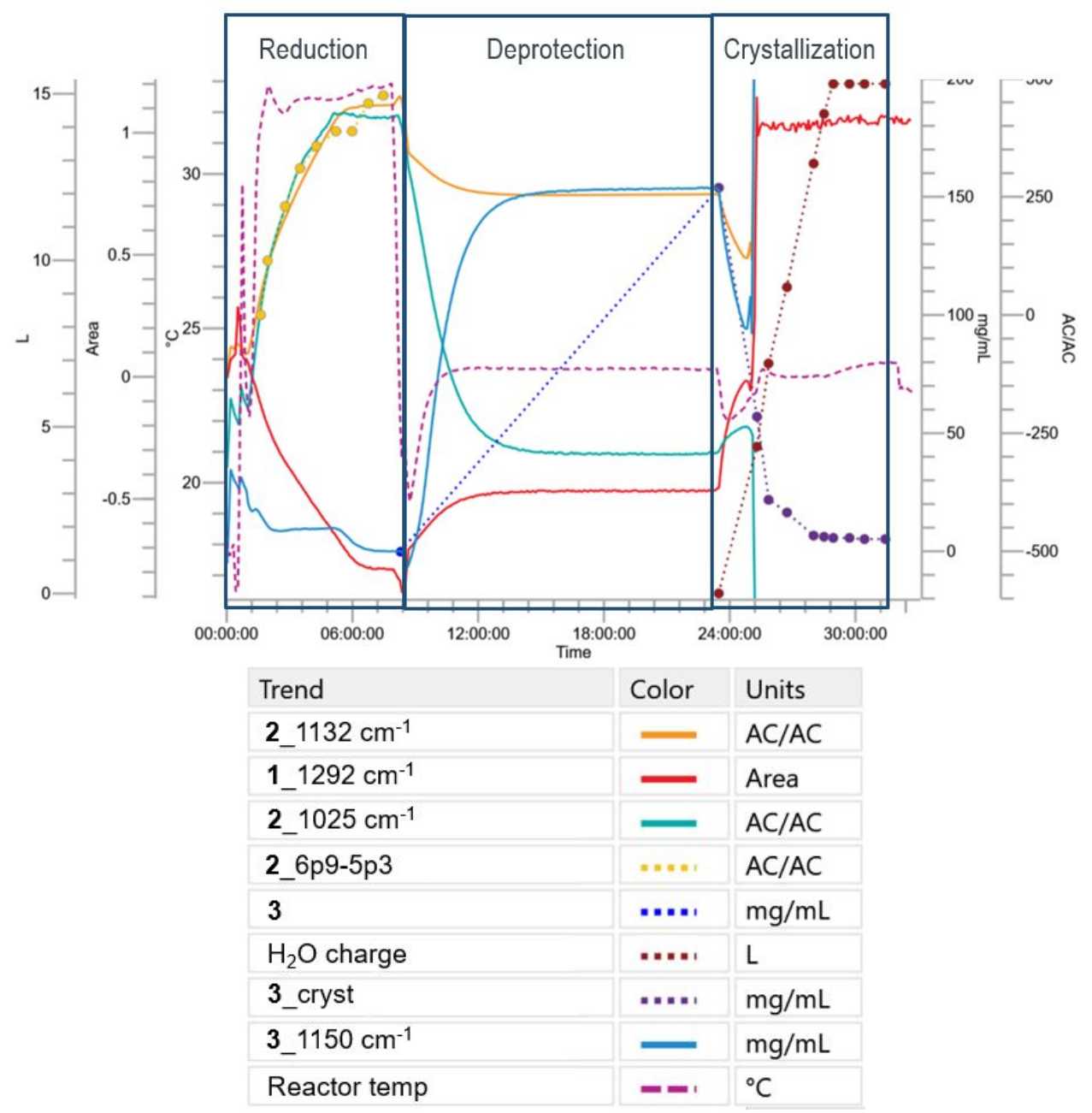

Figure S4. PAT (IR) monitoring and trends for the reaction profiles.

\subsection{Pilot plant}

This section includes data and figures from the scale-up of the hydroxy indanone intermediate (3) process at the Small Scale Organics (SSO) pilot plant in Rahway, NJ. The full procedure is described in the Manufacture of hydroxy indanone 3 section. Final packaged drycake data and impurity profile is reported in the manuscript in Table 3.

The reaction progressed as expected and was complete after 6 hours, which corresponded to previous experience on lab scale. The hydroxy ketal intermediate was not detected in any sample, demonstrating the effectiveness and robustness of the $0.0175 \mathrm{Nm}^{3} / \mathrm{h} / \mathrm{kg}$ nitrogen sweep rate. 
The reaction progressed as expected. Low levels of impurity $\mathbf{4}$ indicate that cooling the batch and shutting down the nitrogen sweep after the reduction reaction effectively stops reaction progression and subsequent impurity $\mathbf{4}^{\prime}$ generation.

Table S2. Key data obtained from samples taken at multiple time points during the reduction reaction at pilot plant.

\begin{tabular}{ccccc}
\hline Entry & $\begin{array}{c}\text { Sample Time } \\
(\mathrm{h})\end{array}$ & $\begin{array}{c}\mathbf{1} \\
(\mathrm{LCAP})\end{array}$ & $\begin{array}{c}\mathbf{2} \\
(\mathrm{LCAP})\end{array}$ & $\begin{array}{c}\mathbf{4}^{\prime} \\
(\mathrm{LCAP})\end{array}$ \\
\hline 1 & 1.35 & 62.6 & 36.7 & 0.0 \\
2 & 2.35 & 41.0 & 58.8 & 0.0 \\
3 & 3.35 & 15.2 & 84.5 & 0.0 \\
4 & 4.35 & 1.2 & 98.5 & 0.0 \\
5 & 6.35 & 0.1 & 99.7 & 0.0 \\
\hline
\end{tabular}

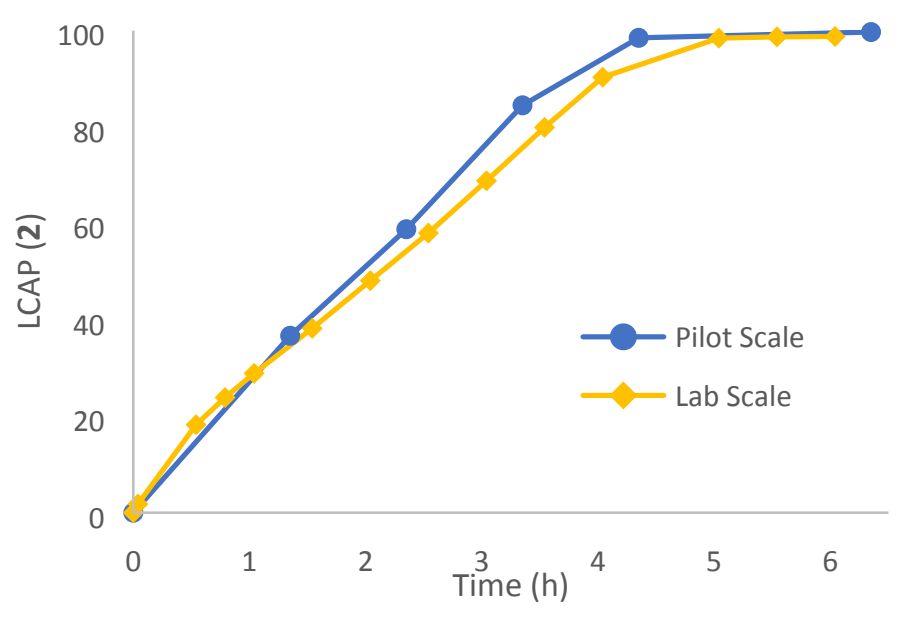

Figure S5. Overlay of lab scale front run data with pilot scale data both using $0.0175 \mathrm{Nm} / \mathrm{h} / \mathrm{kg}$ nitrogen sweep rate, demonstrating a robust and scalable process. 
Table S3. Key data obtained from samples taken at multiple time points during the deprotection reaction at pilot plant.

\begin{tabular}{ccccc}
\hline Entry & $\begin{array}{c}\text { Sample Time } \\
(\mathrm{h})\end{array}$ & $\begin{array}{c}\mathbf{2} \\
(\mathrm{LCAP})\end{array}$ & $\begin{array}{c}\mathbf{3} \\
(\mathrm{LCAP})\end{array}$ & $\begin{array}{c}\mathbf{4} \\
(\mathrm{LCAP})\end{array}$ \\
\hline 1 & 1 & 30.18 & 69.75 & 0.06 \\
2 & 3 & 7.83 & 92.05 & 0.12 \\
3 & 7 & 0.71 & 99.17 & 0.12 \\
4 & 9 & 0.28 & 99.60 & 0.12 \\
\hline
\end{tabular}

\section{Impact of upstream starting material 1}

Having established suitable conditions for the new process on repurified ketone starting material (1), some inconsistencies were encountered when moving to more representative material from the newly developed upstream route. A large difference was noted in the slower reaction kinetics. Because of known starting-material insolubility in $\mathrm{MeCN}$, particle size distribution (PSD) and specific surface area (SSA) were investigated but did not provide any correlation to rate. After eliminating physical effects, an investigation was started to identify potential sources of chemical poisons to the $\mathrm{Ru}$ catalyst. Various suspect inhibitors from the upstream chemistry (including a through-process Bromination/Oxidation) were spiked into the reaction to characterize inhibition risk. It was discovered that even trace levels of brominated impurities could slow down this reduction reaction; therefore, vigorous efforts to eliminate these impurities and improve the quality of the starting material 1 were followed. Fate and purge of other impurities coming from upstream were also investigated, and proper material specifications were thus set. Of note, one critical contaminant was the enantiomer of intermediate $\mathbf{2}$, formed in the oxidation step, which was found to impact the enantioselectivity of compound $\mathbf{3}$.

\section{Time cycle calculation for first and second generation process}

We compared the first generation process with the current one. The first process had 2 extractions, 2 vacuum concentrations, a carbon treatment, and longer reaction times for both reduction and deprotection parts. After reviewing the batch records, we realized that they both operated around the clock, and so comparing batch start and stop times for the entire batch is a pretty good 
comparison. Based on Tables shown below 30\% time cycle reduction was obtained (whether taking avg time cycle at each site, or just looking at the best time cycle from each site).

Table S4. Time cycle calculations for first generation (A) versus final commerical process (B).

\begin{tabular}{|c|c|l|}
\hline Batch ID & duration & \\
\hline B- Batch 1 & 5.5 & days \\
\hline B- Batch 2 & 6.2 & days \\
\hline B- Batch 3 & 6.0 & days \\
\hline B- Batch 4 & 5.5 & days \\
\hline B- Batch 5 & 6.0 & days \\
\hline & & \\
\hline average & 5.9 & days \\
\hline
\end{tabular}

\begin{tabular}{|c|c|l|}
\hline Batch ID & duration & \\
\hline A- Batch 1 & 9.2 & days \\
\hline A- Batch 2 & 9.1 & days \\
\hline A- Batch 3 & 7.9 & days \\
\hline A- Batch 4 & 7.7 & days \\
\hline & & \\
\hline & & \\
\hline average & 8.5 & days \\
\hline
\end{tabular}

\begin{tabular}{|l|c|}
\hline$\%$ reduction (avg) & $31 \%$ \\
\hline$\%$ reduction (best) & $28 \%$ \\
\hline
\end{tabular}




\section{$\underline{\text { 4. Reaction and process optimization }}$}

\subsection{Reaction optimizations}

Table S5. Initial solvent screening for the reduction reaction.

Solvent $(6.7 \mathrm{vol}), 25-30{ }^{\circ} \mathrm{C}$

$\mathrm{C}$


Table S6. Solvent screening for the reduction reaction under stressed condition.

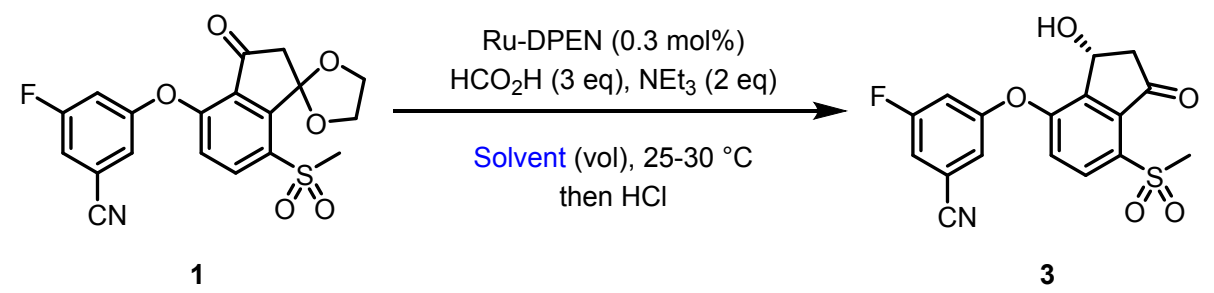

\begin{tabular}{ccccc}
\hline Solvent & $\boldsymbol{e e}$ & LCAP (3) & $\begin{array}{c}\text { Stressed condition } \\
\text { (LCAP 3) }\end{array}$ & $\begin{array}{c}\text { Stressed condition } \\
(\boldsymbol{e e} \text { 3) }\end{array}$ \\
\hline MeCN & $>99$ & 99.5 & 98.4 & 99.2 \\
EtOAc & $>99$ & 96.9 & 94.9 & 97.4 \\
Triethyl Phosphate & $>99$ & 95.4 & 96.5 & 99.0 \\
Propylene carbonate & $>99$ & 97.5 & 95.2 & 99.1 \\
Sulfolane & $>99$ & 97.4 & 97.3 & 99.6 \\
\hline
\end{tabular}

Table S7. Optimization of triethylamine and formic acid.

\begin{tabular}{ccccc}
\hline Entry & TEA (eq) & FA (eq) & LCAP (2) & $\boldsymbol{e e ~ ( 2 ) ~}$ \\
\hline A & 1.1 & 1.1 & 98.69 & 99.7 \\
B & 1.1 & 1.5 & 99.19 & 99.7 \\
$\mathbf{C}$ & 1.5 & 1.5 & 99.15 & 99.7 \\
$\mathbf{D}$ & 1.5 & 2.0 & 99.23 & 99.6 \\
$\mathbf{E}$ & 2.0 & 1.5 & 98.95 & 99.7 \\
$\mathbf{F}$ & 2.0 & 2.0 & 99.21 & 99.7 \\
$\mathbf{G}$ & 1.1 & 1.1 & 99.11 & - \\
$\mathbf{H}$ & 1.1 & 0.8 & 65.4 & - \\
$\mathbf{I}$ & 0.8 & 0.8 & 65.63 & - \\
$\mathbf{J}$ & 0.8 & 1.1 & 99.18 & - \\
\hline
\end{tabular}

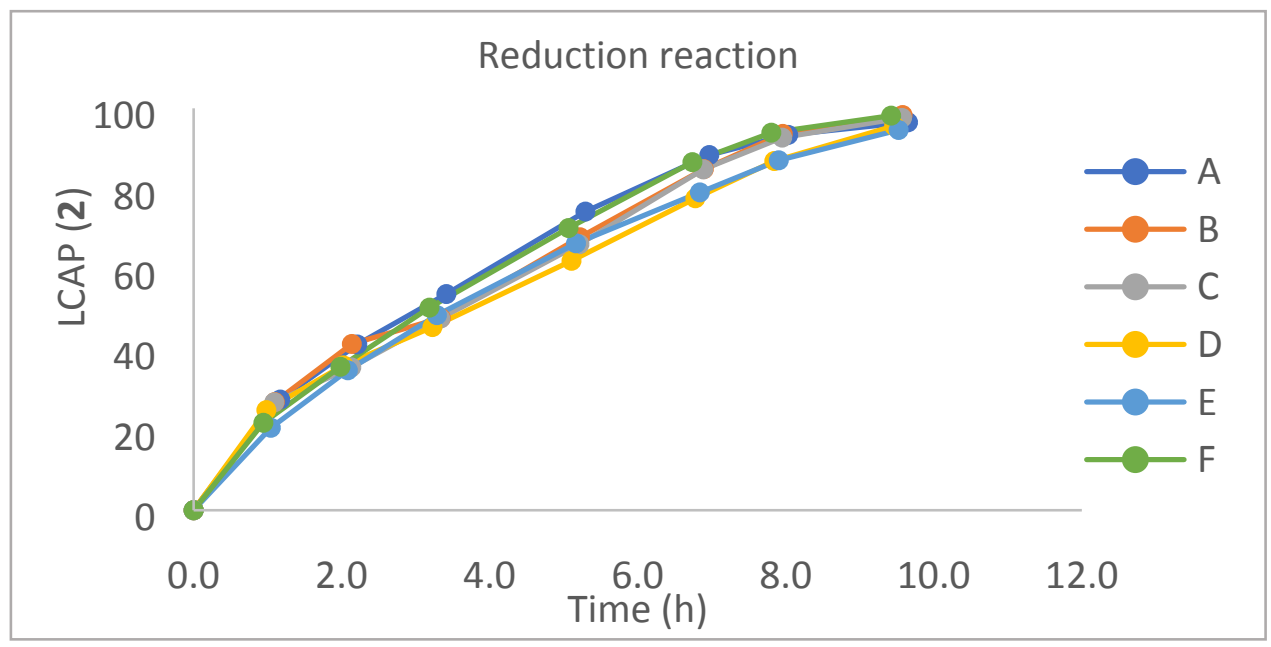


Table S8. Impact of vendor of Ru-DPEN on purity.

\begin{tabular}{ccc}
\hline Vendor & LCAP (2) & $\boldsymbol{e e ~ ( 2 ) ~}$ \\
\hline JM & 99.07 & 99.6 \\
Sigma & 99.03 & 99.6 \\
STREM & 98.65 & 99.4 \\
TCI & 99.07 & 99.7 \\
\hline
\end{tabular}

Table S9. Acid screening for the deprotection step.

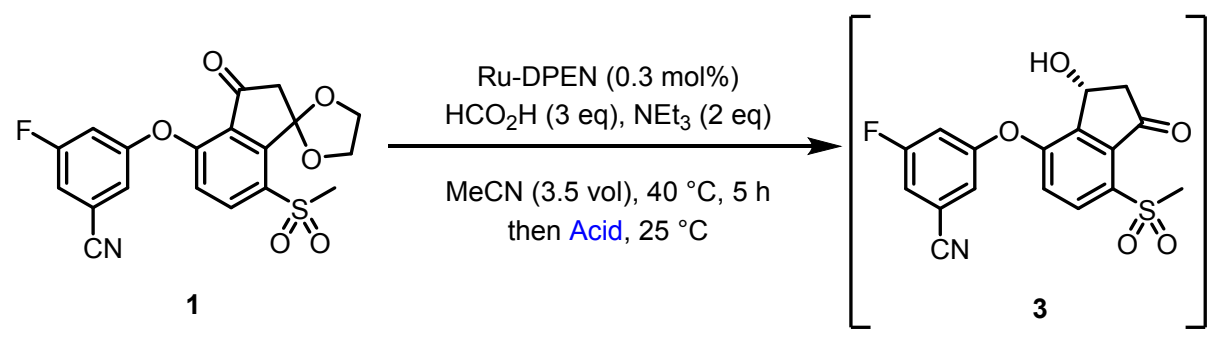

\begin{tabular}{ccccc}
\hline Entry & Acid Source & Acid (eq) & Water (vol) & $\begin{array}{c}\text { 3 (LCAP)- } \\
\text { 1day }\end{array}$ \\
\hline $\mathrm{A}$ & $\mathrm{HCl}(4 \mathrm{M})$ & 1.6 & - & 1.2 \\
$\mathrm{~B}$ & $\mathrm{HCl}(4 \mathrm{M})$ & 2 & - & 99.1 \\
$\mathrm{C}$ & $\mathrm{HCl}(4 \mathrm{M})$ & 2.6 & - & 99.2 \\
$\mathrm{D}$ & $\mathrm{HCl}(1 \mathrm{M})$ & 2 & - & 86.1 \\
$\mathrm{E}$ & $\mathrm{H}_{2} \mathrm{SO}_{4}$ & 1.6 & 1 & 37.5 \\
$\mathrm{~F}$ & $\mathrm{H}_{2} \mathrm{SO}_{4}$ & 2.6 & - & 87.2 \\
$\mathrm{G}$ & $\mathrm{H}_{2} \mathrm{SO}_{4}$ & 2.6 & 1 & 97.9 \\
$\mathrm{H}$ & $\mathrm{pTsOH}_{4} \mathrm{H} 2 \mathrm{O}$ & 0.5 & 1 & trace \\
$\mathrm{I}$ & $\mathrm{pTsOH} . \mathrm{H} 2 \mathrm{O}$ & 2.6 & 1 & 99.2 \\
$\mathrm{~J}$ & $\mathrm{H}_{3} \mathrm{PO}_{4}$ & 1.4 & 1 & 2.7 \\
$\mathrm{~K}$ & $\mathrm{H}_{3} \mathrm{PO}_{4}$ & 2.2 & 1 & 14.4 \\
$\mathrm{~L}$ & $\mathrm{MsOH}_{\mathrm{MsOH}}$ & 1.6 & - & 11.3 \\
$\mathrm{M}$ & $\mathrm{MsOH}$ & 2.6 & - & 95.1 \\
$\mathrm{~N}$ & $\mathrm{MsOH}$ & 2.6 & 1 & 99.2 \\
$\mathrm{O}$ & $\mathrm{AcOH}$ & 2.6 & 1 & trace \\
$\mathrm{P}$ & $\mathrm{AcOH}$ & 2.6 & 1 & trace \\
$\mathrm{Q}$ & $\mathrm{Citric} \mathrm{acid}$ & 1.6 & 1 & trace \\
$\mathrm{R}$ & $\mathrm{Citric} \mathrm{acid}$ & 2.6 & - & trace \\
$\mathrm{S}$ & $\mathrm{Citric} \mathrm{acid}$ & 2.6 & 1 & trace \\
\hline
\end{tabular}




\subsection{Impact of water on kinetics and impurity profile}

Effect of water on rate and impurity profile was more clear when reaction was performed under stressed condition. More water was required to improve EOR stability of the stressed condition $(>15 \mathrm{k} \mathrm{Kf})$. Rate of the reaction is similar at varioud $\mathrm{Kf}$ for control condition, but the gap is slightly larger upon using stressed condition. Based on these experiments, we found that at high Kf, the level of dimer impurity is suppressed to form more alcohol after EOR. We also discovered that changing the equivalents of $\mathrm{Et}_{3} \mathrm{~N}$ or Formic acid doesn't impact EOR stability significantly. However higher formic acid to $\mathrm{Et}_{3} \mathrm{~N}$ ratio reduces the reatcion rate due to longer incubation period.
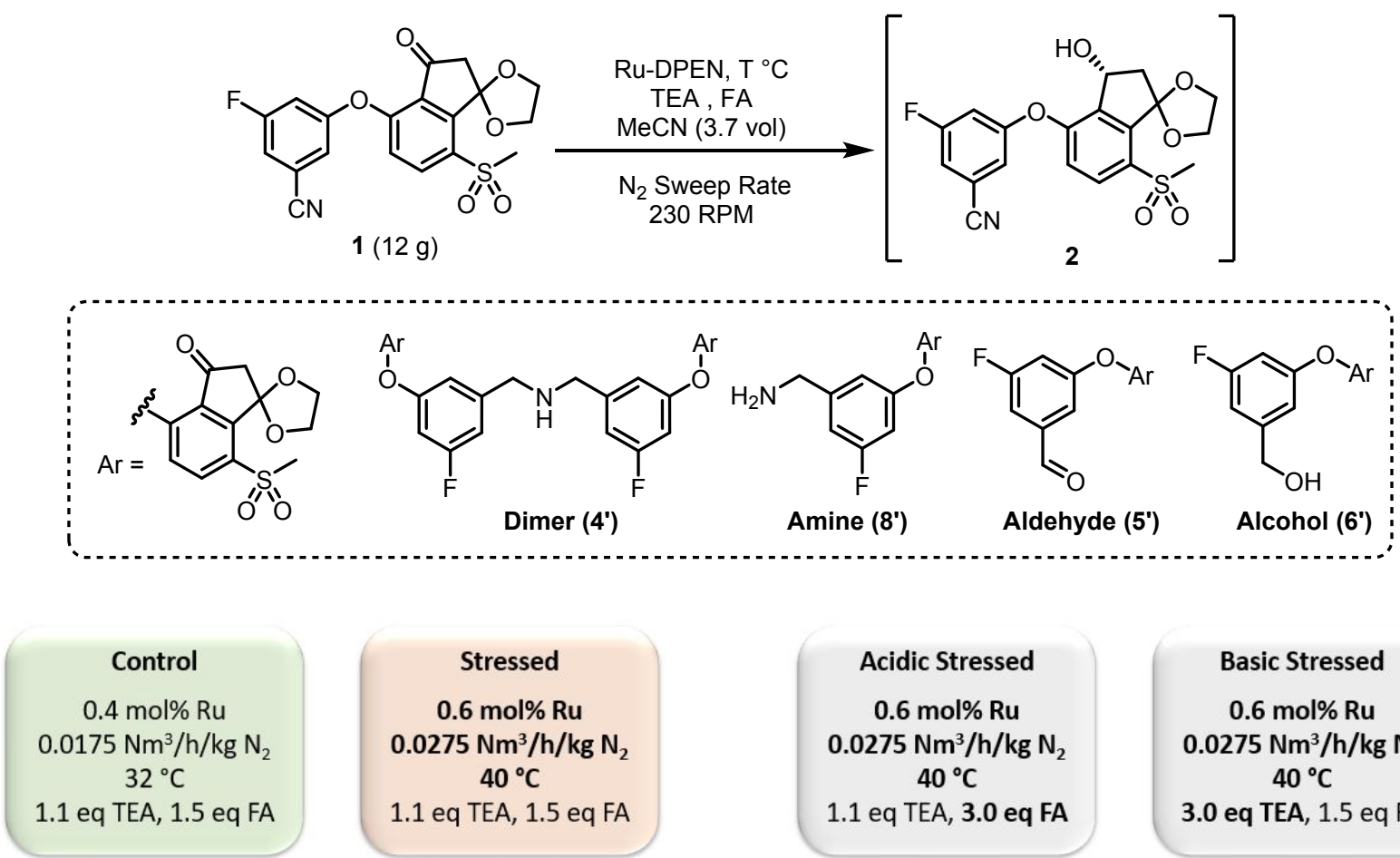

Figure S6. Control versus Stressed Conditions. 


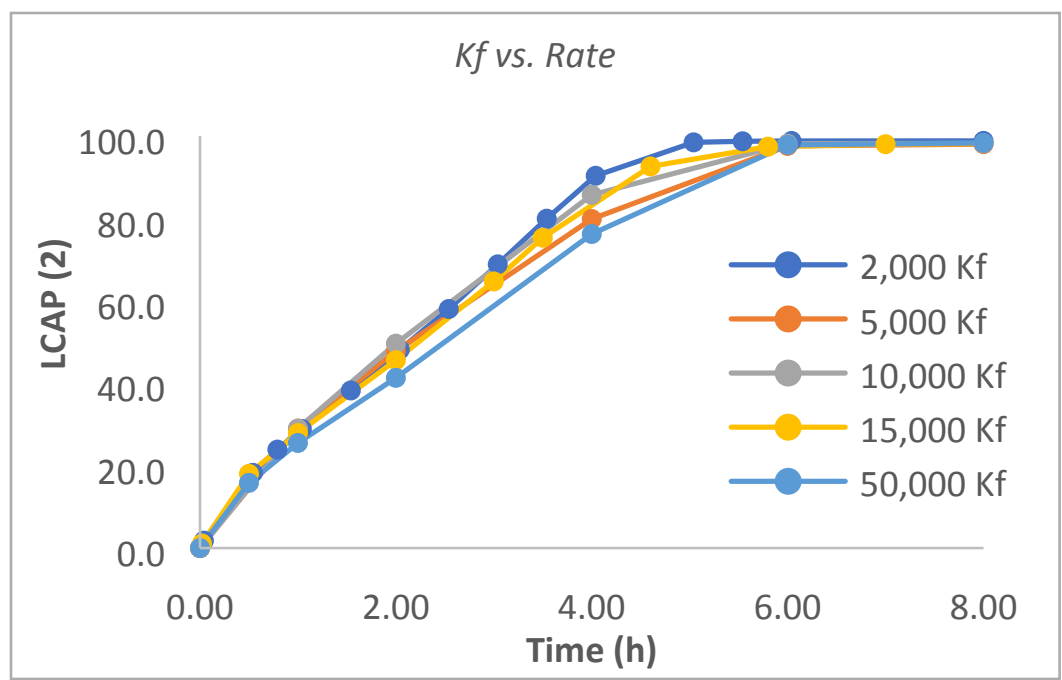

\begin{tabular}{cc}
\hline $\mathbf{H}_{2} \mathbf{O}(\mathbf{e q})$ & $\mathbf{K f} \mathbf{p p m}$ \\
\hline 0.00 & $\sim 2,000(2 \mathrm{k})$ \\
0.20 & $\sim 5,000(5 \mathrm{k})$ \\
0.57 & $\sim 10,000(10 \mathrm{k})$ \\
1.00 & $\sim 15,000(15 \mathrm{k})$ \\
3.33 & $\sim 50,000(50 \mathrm{k})$ \\
\hline
\end{tabular}

Figure S7. Impact of water additive on reaction rate for control condition

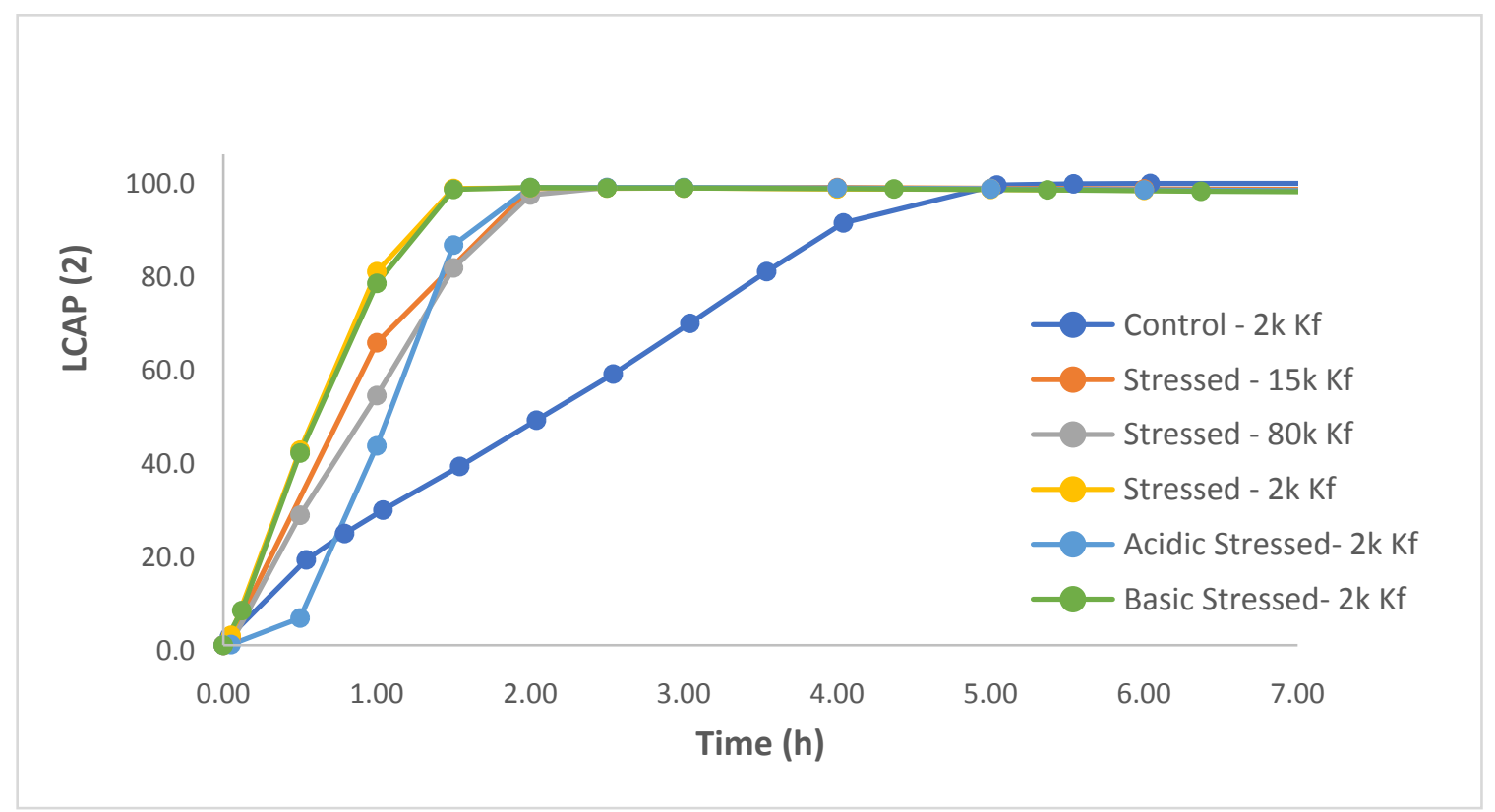

Figure S8. Impact of water on the reaction rate for control and stressed conditions. 


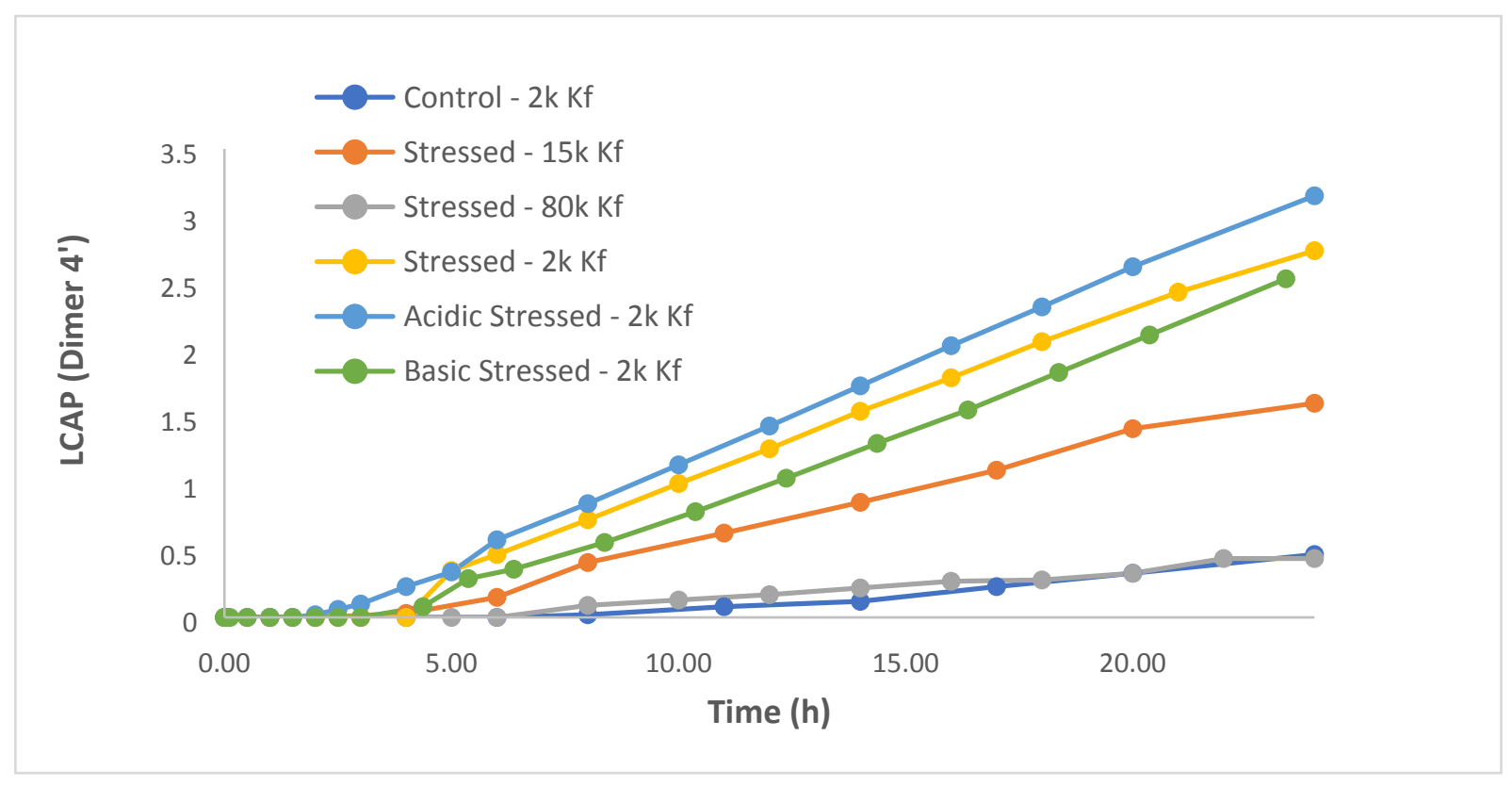

Figure S9. Impact of water on dimer impurity for control and stressed conditions.

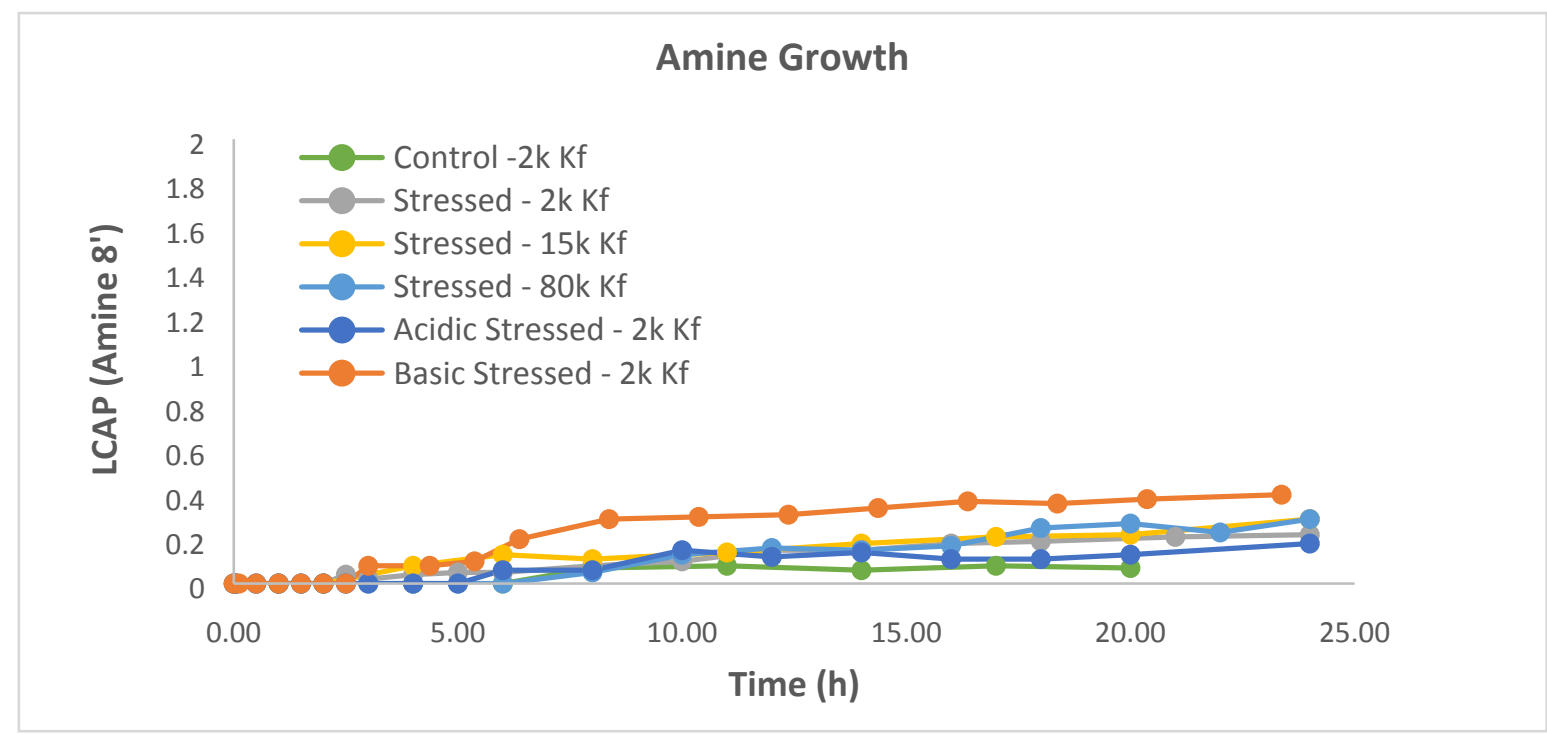

Figure S10. Impact of water on amine impurity for control and stressed conditions. 


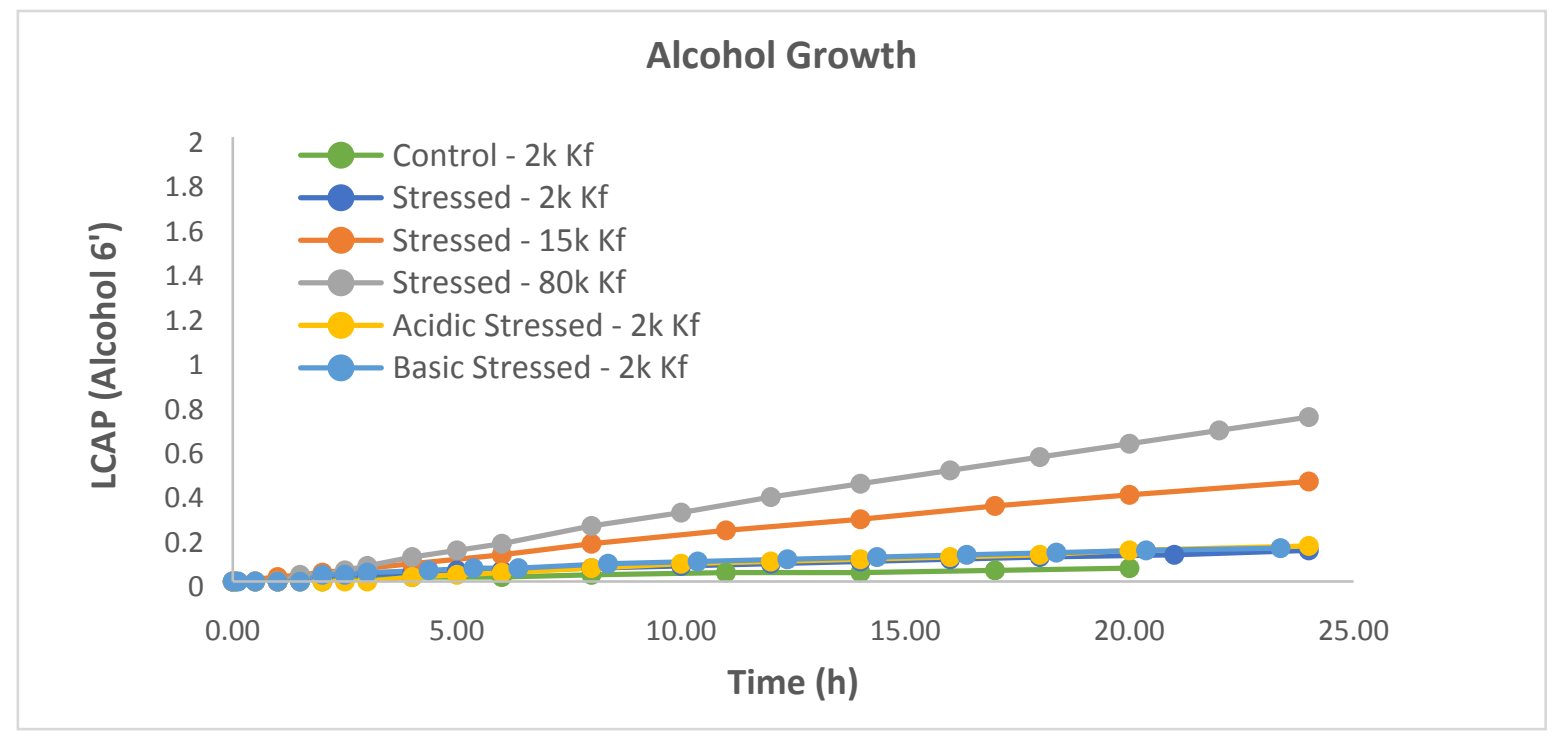

Figure S11. Impact of water on alcohol impurity for control and stressed conditions.

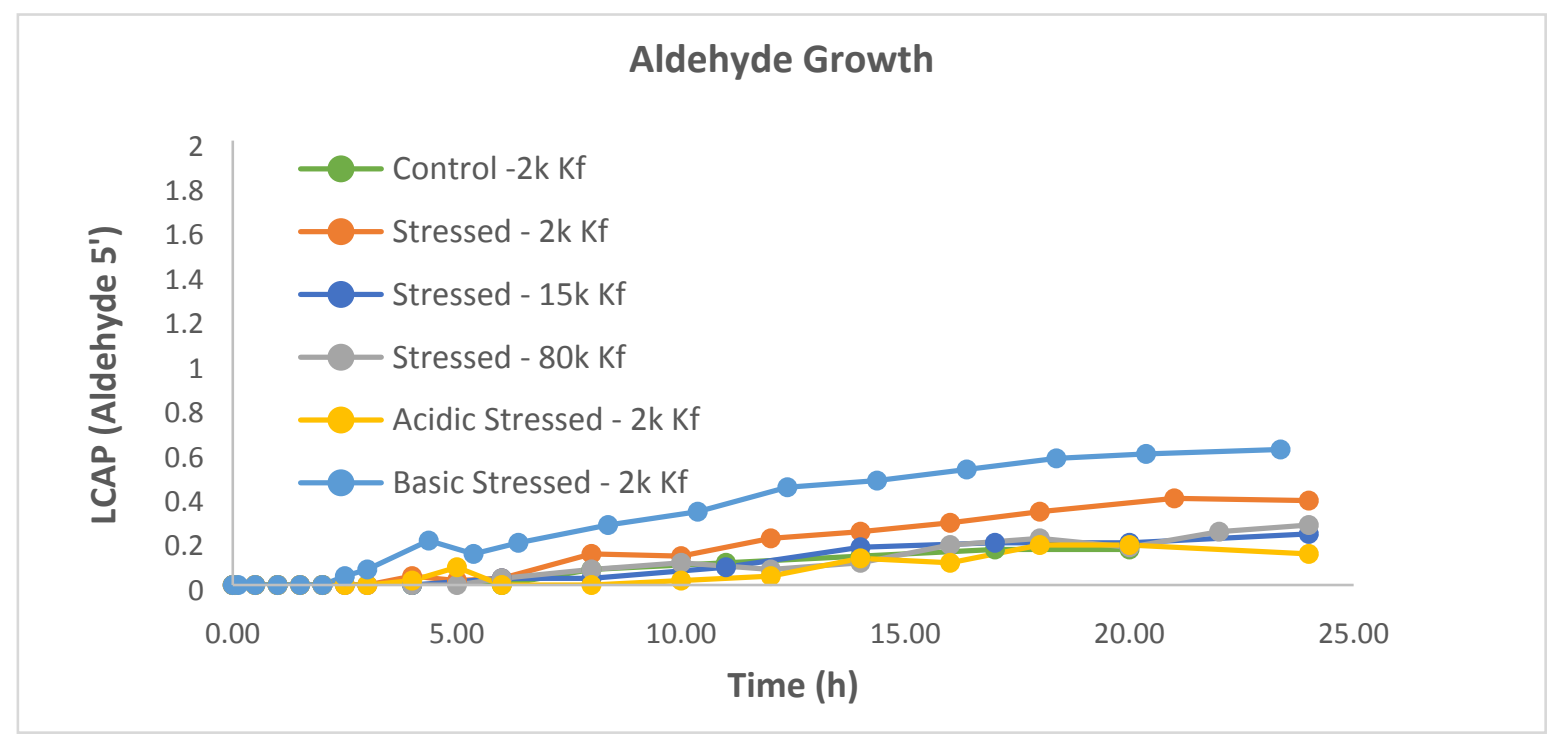

Figure S12. Impact of water on aldehyde impurity for control and stressed conditions. 


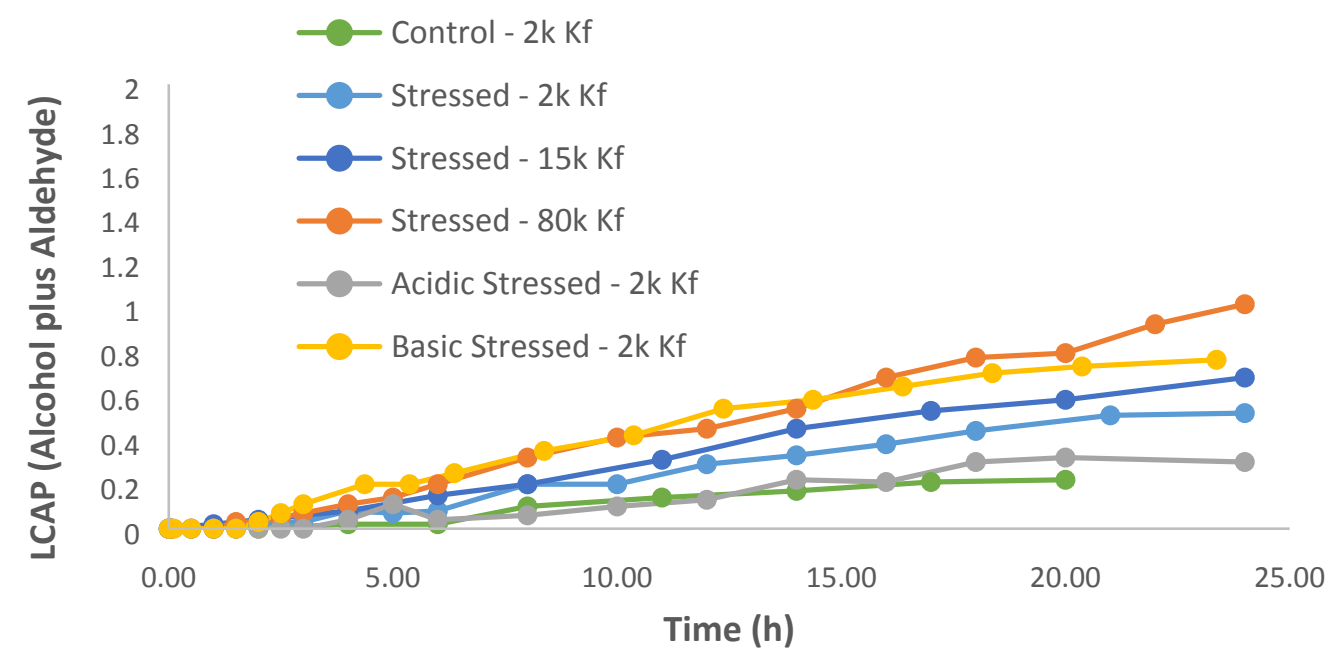

Figure S13. Impact of water on aldehyde plus alcohol impurity for control and stressed conditions.

Table S10. Impact of water additive on the quality of isolated solid 3 under stressed deprotection/crystallization conditions.

\begin{tabular}{cccccccc}
\hline Entry & Kf ppm & $\begin{array}{c}\text { Reduction } \\
\text { age time }\end{array}$ & $\begin{array}{c}\text { Deprotection } \\
\text { condition }\end{array}$ & $\begin{array}{c}\text { Crystallization } \\
\text { condition }\end{array}$ & LCAP & Wt\% & ee \\
\hline 1 & $\sim 1500$ & $6-7 \mathrm{~h}$ & $1.3 \mathrm{eq} \mathrm{HCl}(4 \mathrm{M}), 25{ }^{\circ} \mathrm{C}$ & 12 vol $\mathrm{H}_{2} \mathrm{O}$ over $6 \mathrm{~h}, 20{ }^{\circ} \mathrm{C}$ & 99.84 & 99.10 & 99.61 \\
2 & $\sim 5,000$ & $24.0 \mathrm{~h}$ & $1.3 \mathrm{eq} \mathrm{HCl}(4 \mathrm{M}), 25{ }^{\circ} \mathrm{C}$ & 9 vol $\mathrm{H}_{2} \mathrm{O}$ over $6 \mathrm{~h}, 25{ }^{\circ} \mathrm{C}$ & 99.35 & 98.92 & 99.5 \\
3 & $\sim 15,000$ & $25.0 \mathrm{~h}$ & $1.3 \mathrm{eq} \mathrm{HCl}(4 \mathrm{M}), 25{ }^{\circ} \mathrm{C}$ & 12 vol $\mathrm{H}_{2} \mathrm{O}$ over $6 \mathrm{~h}, 25{ }^{\circ} \mathrm{C}$ & 99.69 & 98.82 & 99.7 \\
4 & $\sim 15,000$ & $6-7 \mathrm{~h}$ & $1.3 \mathrm{eq} \mathrm{HCl}(4 \mathrm{M}), 25{ }^{\circ} \mathrm{C}$ & 11 vol $\mathrm{H}_{2} \mathrm{O}$ over $6 \mathrm{~h}, 25{ }^{\circ} \mathrm{C}$ & 99.75 & 98.96 & 99.6 \\
5 & $\sim 50,000$ & $14.0 \mathrm{~h}$ & $1.5 \mathrm{eq} \mathrm{HCl}(4 \mathrm{M}), 35{ }^{\circ} \mathrm{C}$ & 13 vol $\mathrm{H}_{2} \mathrm{O}$ over $2 \mathrm{~h}, 10{ }^{\circ} \mathrm{C}$ & 99.73 & 98.81 & 99.7 \\
6 & $\sim 50,000$ & $14.0 \mathrm{~h}$ & $1.5 \mathrm{eq} \mathrm{HCl}(4 \mathrm{M}), 35^{\circ} \mathrm{C}$ & 10 vol $\mathrm{H}_{2} \mathrm{O}$ over $6 \mathrm{~h}, 25{ }^{\circ} \mathrm{C}$ & 99.74 & 97.59 & 99.7 \\
\hline
\end{tabular}




\subsection{Sealed high pressure experiments}

Experiment \#1. The reaction was performed in a sealed high pressure $100 \mathrm{~mL}$ vessel with $15 \mathrm{~g}$ starting material 1 and 60\% fill volume. After charging $0.3 \mathrm{~mol} \% \mathrm{Ru}-\mathrm{DPEN}$ catalyst, vessel was sealed and the reaction was heated to $35^{\circ} \mathrm{C}$, allowing the vessel to pressurize. The pressure equilibrated at $\sim 45 \mathrm{psi}$ at $\sim 24 \mathrm{~h}$. First sample taken at $6 \mathrm{~h}$ indicated slow kinetics with only $83.7 \%$ conversion observed. The reaction was then allowed to age overnight. Second sample was taken at $24 \mathrm{~h}$ which indicated stalled reaction at $\sim 93 \%$ conversion. At $24 \mathrm{~h}$, the pressure was released, and the vessel was vacuum purged three times with $\mathrm{N}_{2}$. The reaction was then allowed to run for another $24 \mathrm{~h}$, a total of $48 \mathrm{~h}$ rxn time. The analysis of overhead gas samples indicated that the headspace sample had $47 \% \mathrm{CO}_{2}$, and $5 \% \mathrm{H}_{2}$. No formic acid vapor or $\mathrm{CO}$ was observed in either of the samples. Dry cake analysis indicated $99.2 \mathrm{wt} \%$ and $99.7 \%$ ee. Performing the rxn in a sealed system did not impact the overall impurity profile of the isolated dry cake. However, slowed kinetics of reduction rxn and eventually stalling of the rxn was observed. The stalled rxn was easily recovered by purging the system with $\mathrm{N}_{2}$. Reaction went to completion without additional charge of Ru-DPEN catalyst.

Table S11. Results of sealed high pressure experiment \#1.

\begin{tabular}{ccccc}
\hline Time & $\mathbf{2}($ LCAP) & $\mathbf{2}(\mathbf{w t} \%)$ & $\mathbf{2}(\mathbf{e e} \%)$ & $\mathbf{4}$ (LCAP) \\
\hline $6 \mathrm{~h}$ & 83.7 & N/A & N/A & 0 \\
$24 \mathrm{~h}$ & 93.4 & N/A & N/A & 0 \\
$48 \mathrm{~h}$ & 99.8 & 99.2 & 99.7 & 0 \\
\hline
\end{tabular}




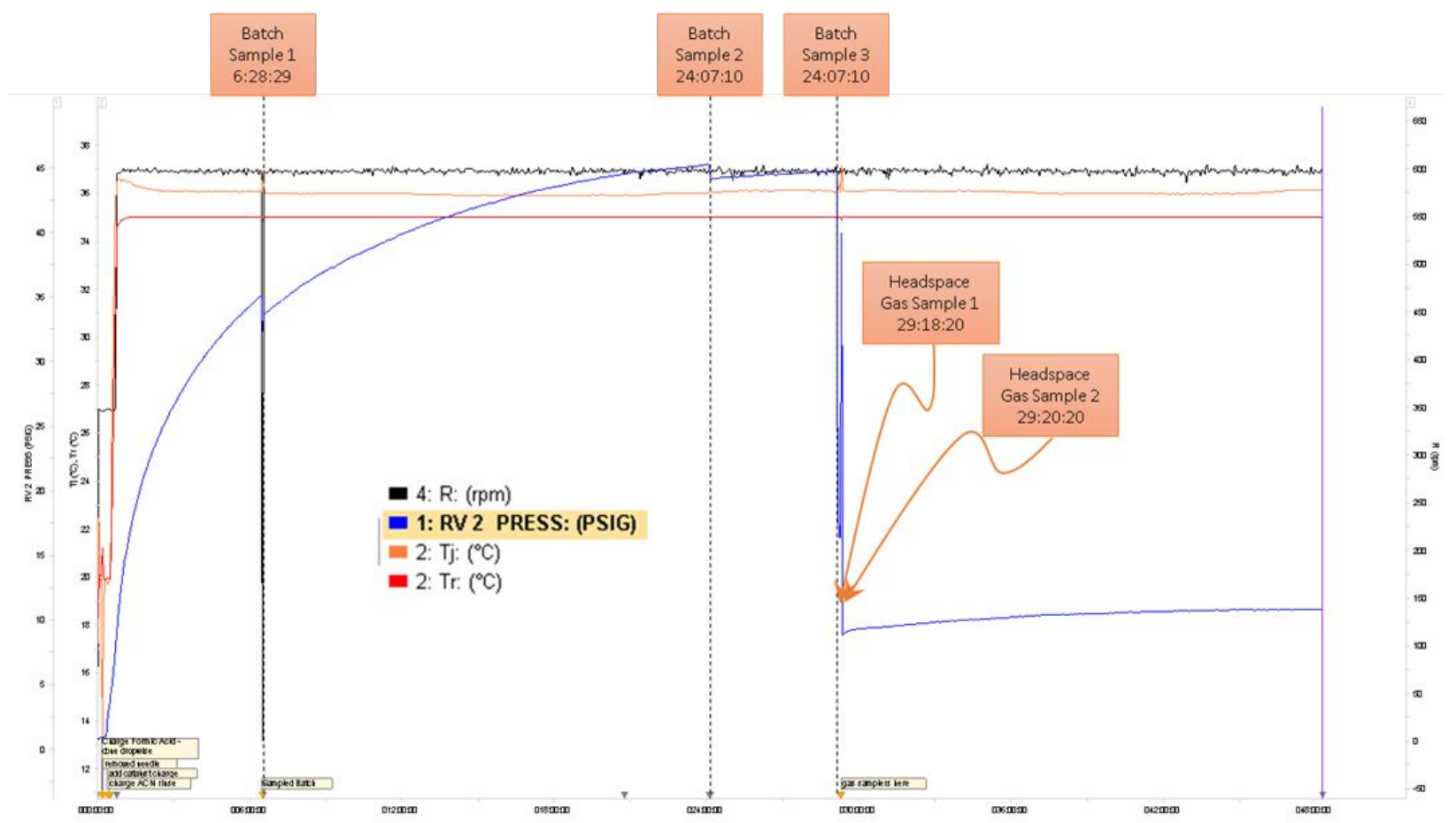

Figure S14. Temperature and pressure profile of the sealed experiment \#1.

Experiment \#2. This experiment was run at a constant pressure of $\sim 10-12$ psig and continuous venting of reactor headspace. The reaction was performed in a sealed high pressure $100 \mathrm{~mL}$ vessel with $15 \mathrm{~g}$ starting material 1 and $60 \%$ fill volume. The overhead gas was vented out to equilibrate the pressure to $\sim 10-12$ psig after 5 hours of reaction time. Reaction sampling of the solution was done every 15 minutes for the first hour, and then every 30 minutes for next two hours, then every hour after that for four hours. At the end of 5 hours, the reaction was at $\sim 93 \%$ conversion. The reduction reaction was allowed to run for a total of $24 \mathrm{~h}$. Dry cake analysis indicated $99.6 \mathrm{wt} \%$ of product 3. Performing the rxn in a sealed system did not impact the overall impurity profile of the isolated dry cake. No dimer impurity was observed in the course of the reaction, indicating the presence of $\mathrm{CO}_{2}$ in reaction overhead/solution would slow down the reaction kinetics of the dimer 4' formation. 


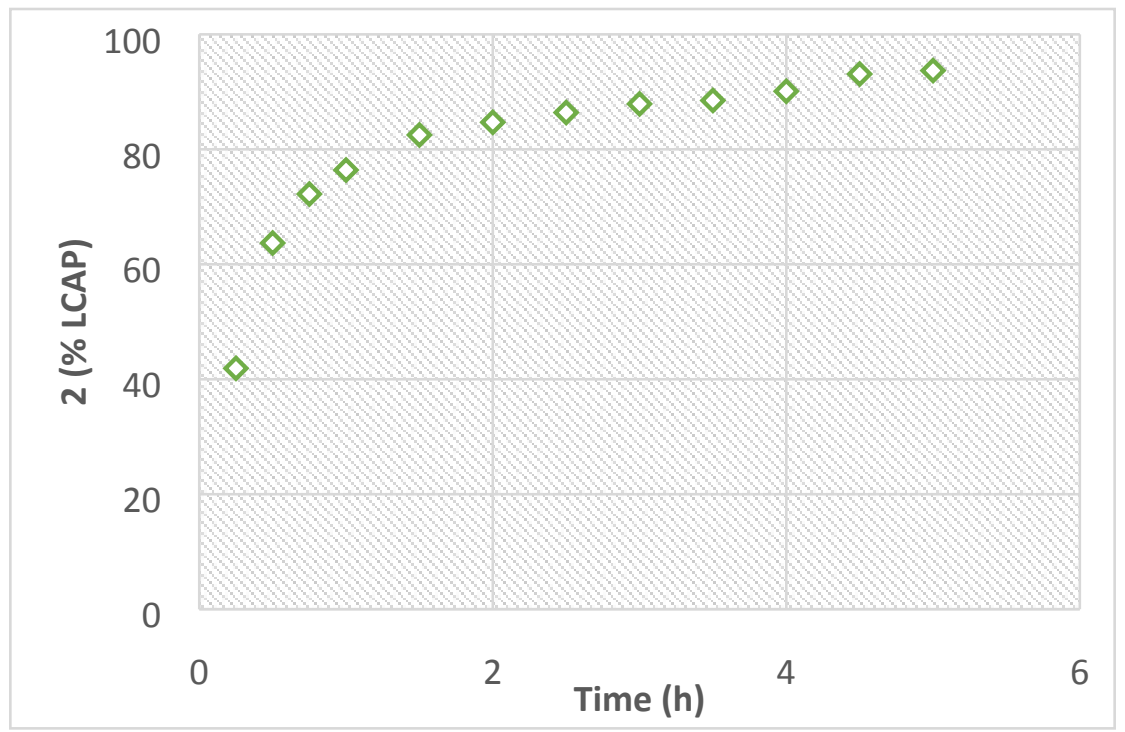

Figure S15. Reaction profile for the sealed experiment \#2.

Experiment \# 3. This experiment was run at sealed high pressure with $\mathrm{N}_{2}$ pressure purges before and after Ru-DPEN charge. The reaction was performed in a sealed high pressure $100 \mathrm{~mL}$ vessel with $15 \mathrm{~g}$ starting material 1 and $60 \%$ fill volume. The reactor was pressure inerted with $\mathrm{N}_{2}$ three times before and after charging $0.3 \mathrm{~mol} \% \mathrm{Ru}-\mathrm{DPEN}$ catalyst. The vessel was sealed and the reaction was heated to $35^{\circ} \mathrm{C}$, allowing the vessel to pressurize. The pressure equilibrated at $\sim 48$ psi in 8 hours. Reduction reaction was allowed to age overnight while sampling every 3 hours. Dry cake analysis indicated $98.9 \mathrm{wt} \%$ of product (3) and 99.6\% ee. Performing the rxn in sealed system did not impact the overall impurity profile of the isolated dry cake. No dimer impurity was observed. The reaction did not show slowed kinetics in this case, likely due to the rapid $\mathrm{CO}_{2}$ removal by pressure purge of the reaction vessel immediately after the addition of Ru-DPEN catalyst. 


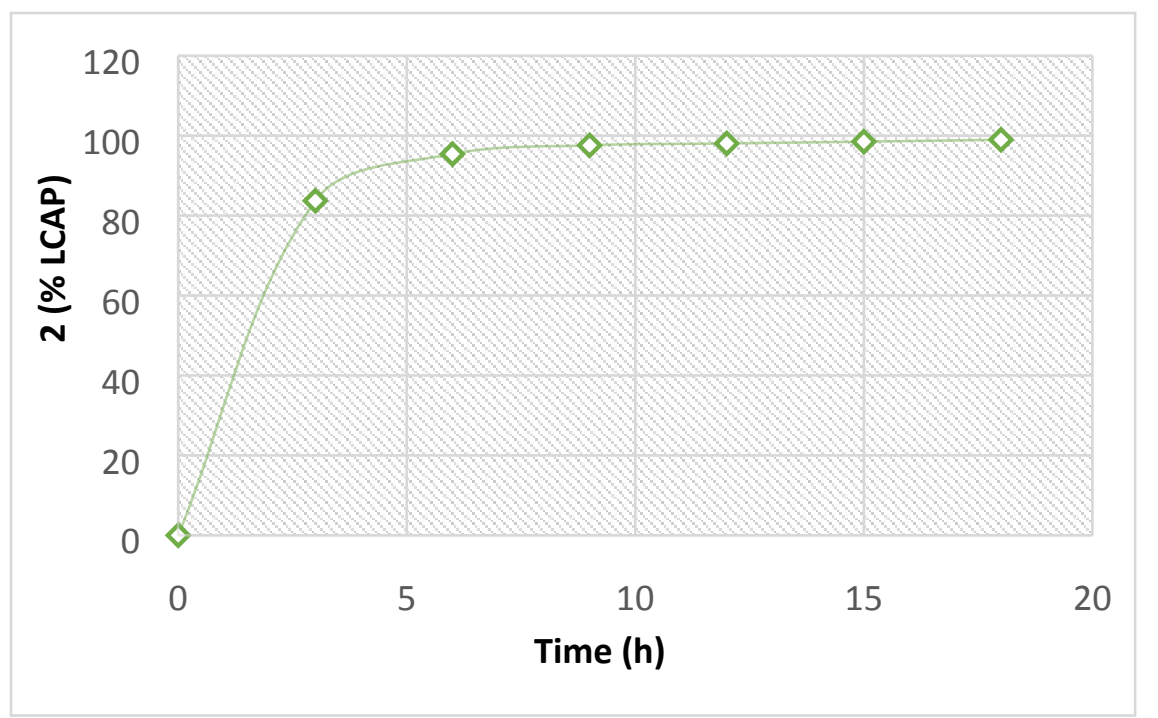

Figure S16. Reaction profile for the sealed experiment \#3.

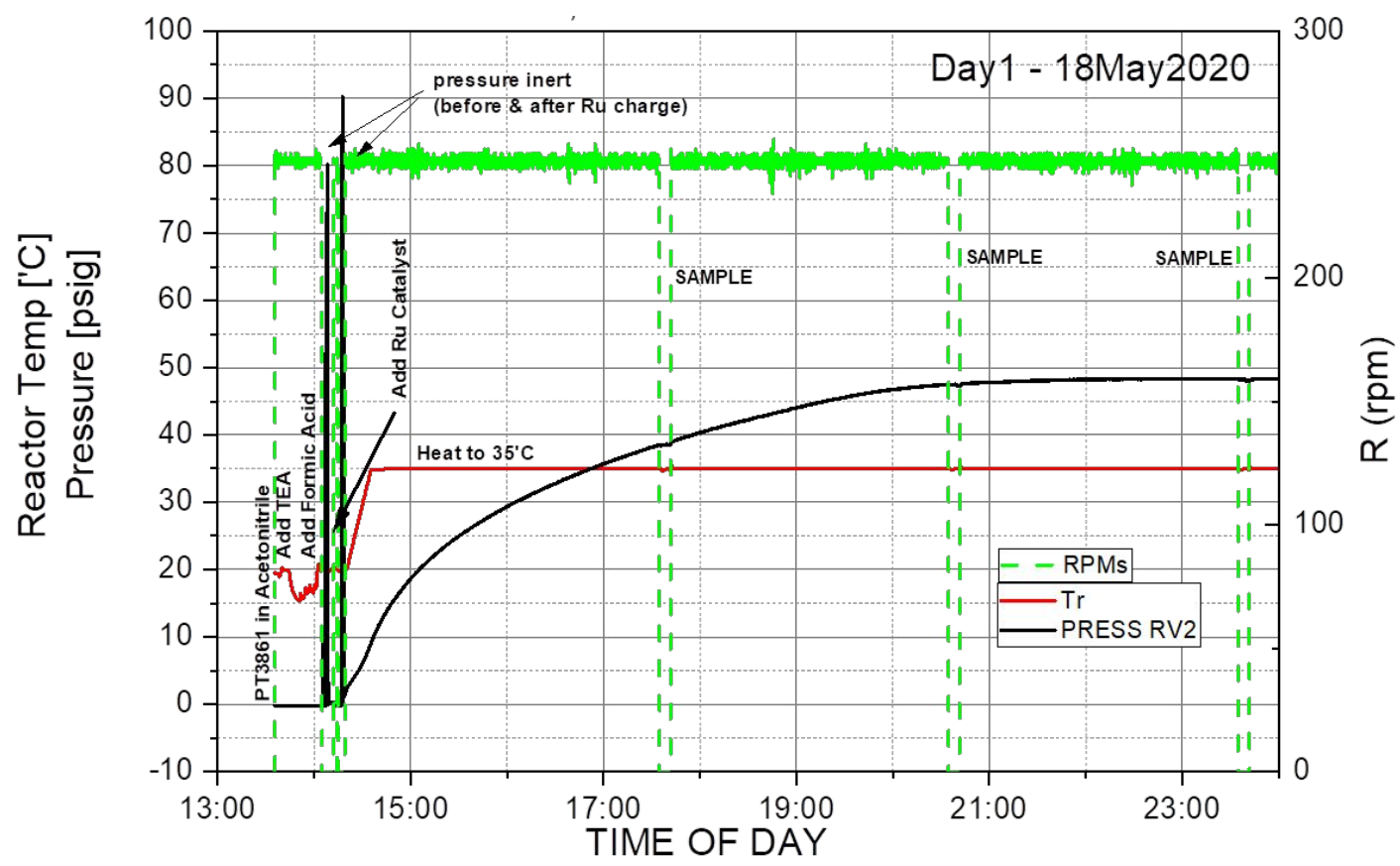

Figure S17. Temperature and pressure profile for the sealed experiment \#3. 


\subsubsection{Impact of vacuum}

Running the reduction reaction under slight vacuum had a significant impact, especially at the beginning after $\mathrm{Ru}$ was charged. The reaction was accelerated significantly due to $\mathrm{CO}_{2}$ removal and depended on the pressure and the length of the vacuum. Since this was not a robust process at scales, we didn't proceed with this approach, and decided to move all the nitrogen purges for inertion of the vessel prior to Ru charge.
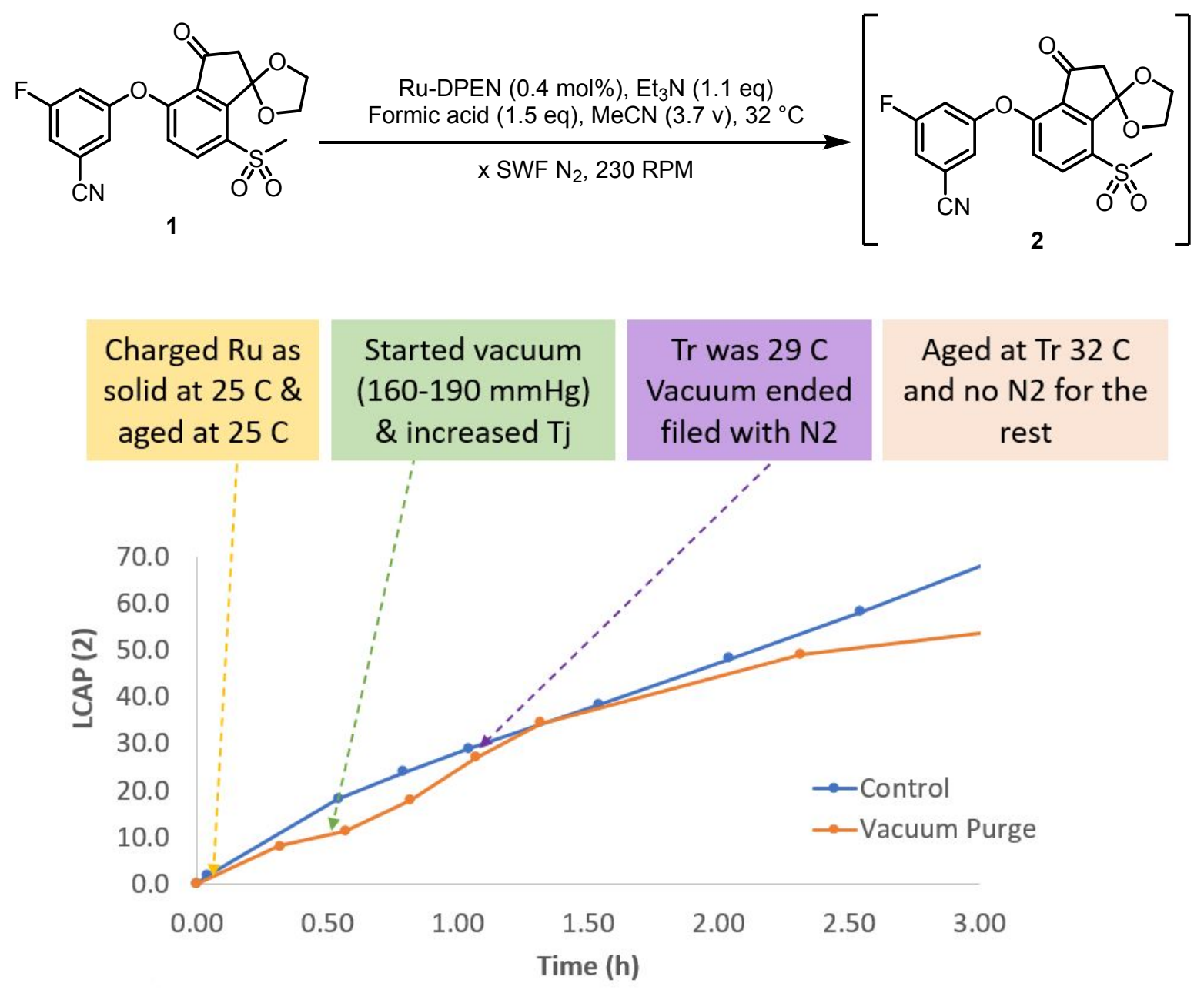

Figure S18. Impact of vacuum on reaction kinetics. 


\subsection{Stability data}

\subsubsection{Subjecting intermediate 2 to the reaction condition}

EOR stability of the reduction reaction was monitored at different nitrogen flow rates as shown in Figure 3. Below, the intermediat 2 was resubjected to the reaction condition at high nitrogen flow rates.

Table S12. Stability of intermediate 2.
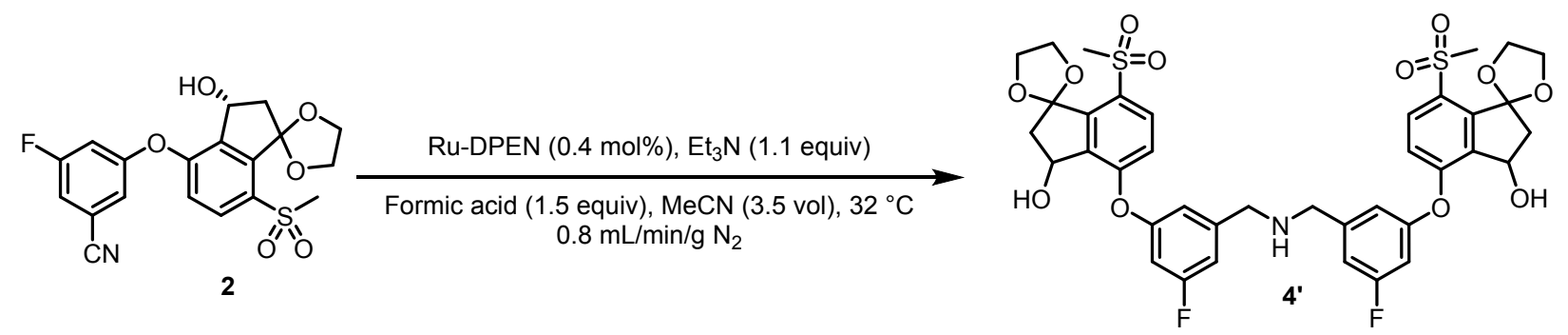

\begin{tabular}{ccc}
\hline Time & 2 (LCAP) & 4' (LCAP) $^{\prime}$ \\
\hline 0.00 & 98.38 & 0.36 \\
0.84 & 97.48 & 0.52 \\
1.63 & 97.66 & 0.55 \\
2.19 & 97.61 & 0.61 \\
4.20 & 97.48 & 0.68 \\
5.13 & 97.44 & 0.73 \\
6.36 & 97.42 & 0.83 \\
8.03 & 97.63 & 0.88 \\
22.30 & 96.48 & 1.69 \\
\hline
\end{tabular}

\subsubsection{Stability of Ru-DPEN catalyst in MeCN}

Ru-DPEN catalyst was dissolved in 0.35 vol MeCN prior to its addition to the reaction mixture. It was aged for 4 hours at room temperature prior to the addition. Reaction went to full ocnversion after 24 hours. The final isolated solid met the expected quality with 99.4 LCAP, 98 wt $\%$, and $90 \%$ isolated yield. Therefore, solution of the catalyst was added to the mixture at the plant scales instead of solid charging. 


\subsection{Optimization of the crystallization process}<smiles>CS(=O)(=O)c1ccc(Oc2cc(F)cc(C#N)c2)c2c1C(=O)CC21CCO1</smiles>

1

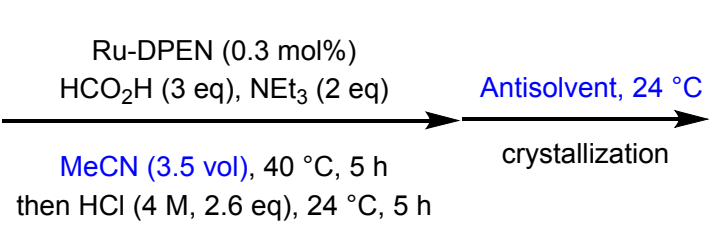
then $\mathrm{HCl}(4 \mathrm{M}, 2.6 \mathrm{eq}), 24^{\circ} \mathrm{C}, 5 \mathrm{~h}$

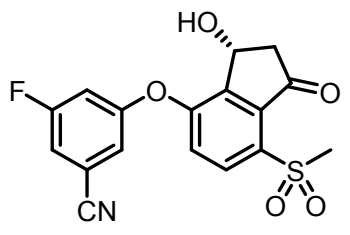

3
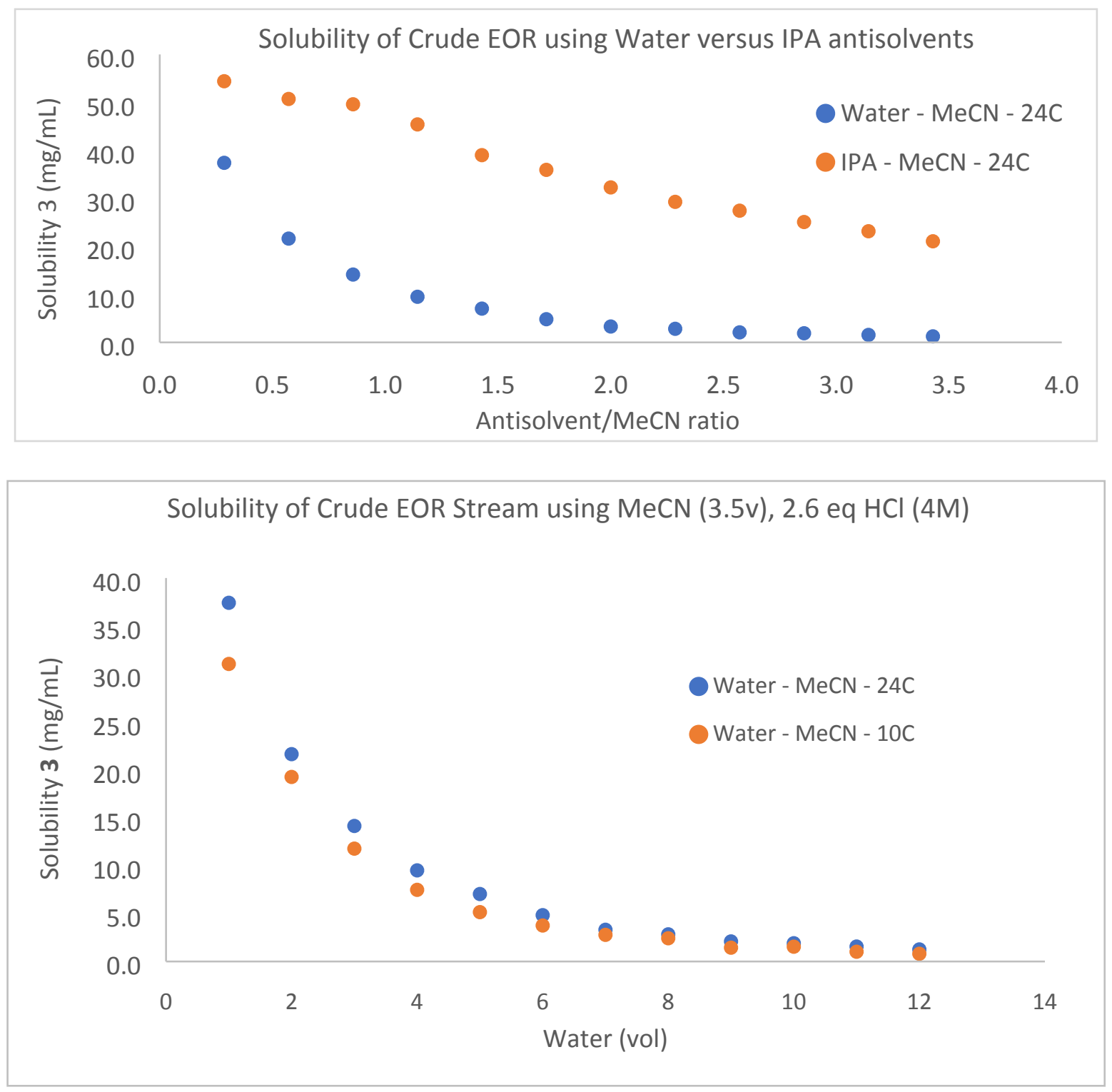

Figure S19. Comparing IPA and water as antisolvents (top) and using water antisolvent at different temperatures (bottom) for the crystallization process. 


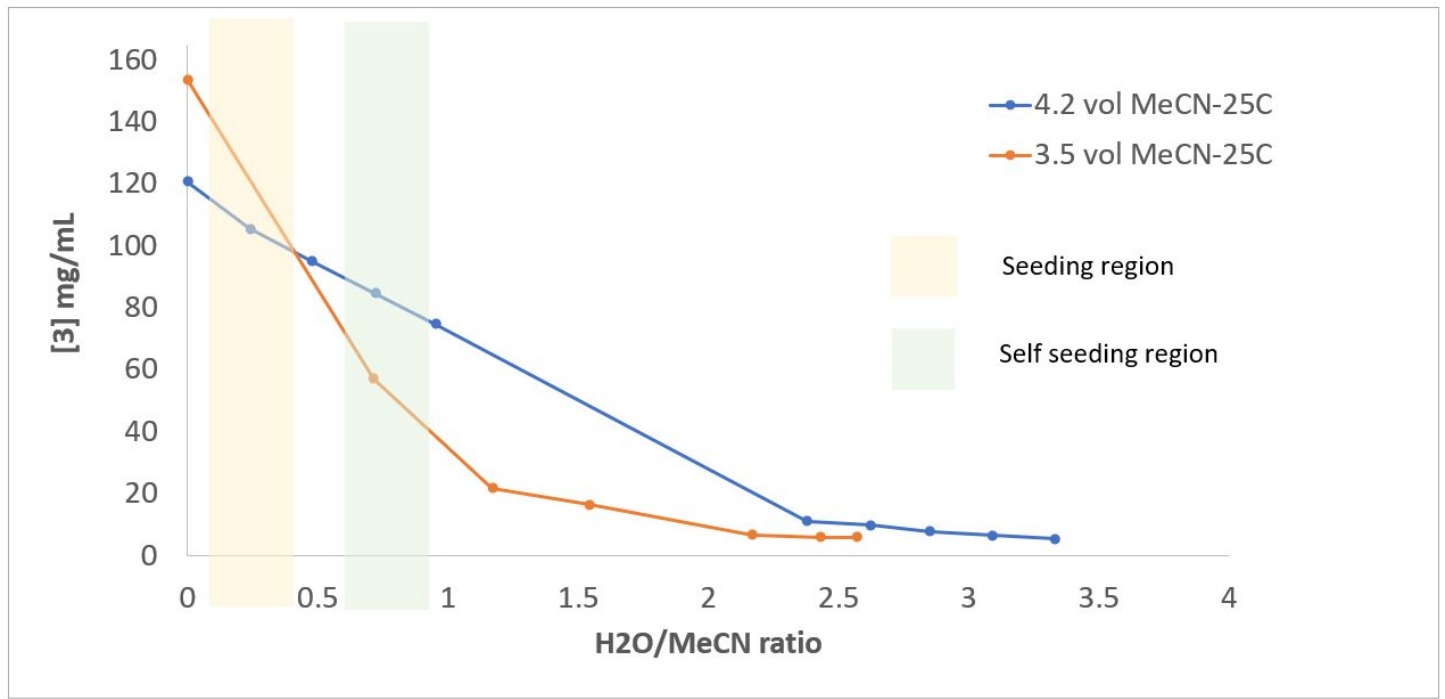

Figure S20. Seeding regime for the crystallization process at different reaction volumes. 
Table S13. Solubility data for compound $\mathbf{1}$ in different solvents.

\begin{tabular}{|c|c|c|}
\hline Entry & Solvent & Solubility (mg/mL) \\
\hline 1 & EtOAc & 5.99 \\
\hline 2 & IPAc & 2.85 \\
\hline 3 & EtOH & 0.32 \\
\hline 4 & IPA & 0.08 \\
\hline 5 & $\mathbf{H}_{2} \mathrm{O}$ & 0 \\
\hline 6 & Acetone & 15.93 \\
\hline 7 & МTBE & 0.30 \\
\hline 8 & Heptane & 0 \\
\hline 9 & DME & 16.04 \\
\hline 10 & МeOH & 0.87 \\
\hline 11 & Toluene & 1.39 \\
\hline 12 & DCM & 85.58 \\
\hline 13 & THF & 20.02 \\
\hline 14 & 2-МеТНF & 4.93 \\
\hline 15 & $\mathrm{ACN}$ & 19.84 \\
\hline 16 & DMF & 85.75 \\
\hline 17 & DMAc & 97.52 \\
\hline
\end{tabular}


Table S14. Solubility data for compound 2 in different solvents.

\begin{tabular}{|c|c|c|}
\hline Entry & Solvent & Solubility $(\mathrm{mg} / \mathrm{mL})$ \\
\hline 1 & EtOAc & 39.45 \\
\hline 2 & IPAc & 17.2 \\
\hline 3 & EtOH & 13.64 \\
\hline 4 & IPA & 5.38 \\
\hline 5 & $\mathrm{H}_{2} \mathrm{O}$ & 0 \\
\hline 6 & Acetone & 145.99 \\
\hline 7 & МТВЕ & 5.74 \\
\hline 8 & Heptane & 0 \\
\hline 9 & NMP & 286.24 \\
\hline 10 & МеОН & 24.83 \\
\hline 11 & Toluene & 4.26 \\
\hline 12 & DCM & 295.76 \\
\hline 13 & THF & 156.81 \\
\hline 14 & 2-MeTHF & 43.08 \\
\hline 15 & $\mathbf{A C N}$ & 63.68 \\
\hline 16 & DMF & 274.94 \\
\hline 17 & DMAc & 339.25 \\
\hline
\end{tabular}


Table S15. Solubility data for compound $\mathbf{3}$ in different solvents.

\begin{tabular}{|c|c|c|}
\hline Entry & Solvent & Solubility $(\mathrm{mg} / \mathrm{mL})$ \\
\hline 1 & EtOAc & 21.05 \\
\hline 2 & IPAc & 7.97 \\
\hline 3 & EtOH & 4.68 \\
\hline 4 & IPA & 2.05 \\
\hline 5 & $\mathrm{H}_{2} \mathrm{O}$ & 0 \\
\hline 6 & Acetone & 95.68 \\
\hline 7 & MTBE & 1.29 \\
\hline 8 & Heptane & 0 \\
\hline 9 & NMP & 591.41 \\
\hline 10 & МеОН & 18.23 \\
\hline 11 & Toluene & 0.61 \\
\hline 12 & DCM & 39.62 \\
\hline 13 & THF & 99.55 \\
\hline 14 & 2-МеТНF & 18.63 \\
\hline 15 & $\mathbf{A C N}$ & 88.75 \\
\hline 16 & DMF & 474.81 \\
\hline 17 & DMAc & 432.1 \\
\hline 18 & CPME & 0.71 \\
\hline 19 & Sulfolane $95 \%$ & 121.54 \\
\hline 20 & TEP & 230.64 \\
\hline 21 & Propylene carbonate & 123.29 \\
\hline
\end{tabular}


Table S16. Solubility data for compound 3 in $\mathrm{MeCN}_{-} \mathrm{H}_{2} \mathrm{O}$ system.

\begin{tabular}{ccc}
\hline Entry & MeCN- $\mathbf{H}_{2} \mathbf{O}$ & Solubility $(\mathbf{m g} / \mathbf{m L})$ \\
\hline 1 & $90-10$ & 130.16 \\
2 & $80-20$ & 113.53 \\
3 & $70-30$ & 83.40 \\
4 & $60-40$ & 55.99 \\
5 & $50-50$ & 32.53 \\
6 & $40-60$ & 14.35 \\
7 & $30-70$ & 5.69 \\
8 & $20-80$ & 1.87 \\
9 & $10-90$ & 0.77 \\
\hline
\end{tabular}

\subsection{Impact of water additive on the quality of isolated solid}

A series of experiments were conducted to assess the impact of adding water ( 0 to 3.33 molar equiv.) to the Reduction reaction on the hydroxy ketal amine dimer and the purity of the isolated hydroxy indanone. A constant $\mathrm{N}_{2}$ sweep rate of $0.0175 \mathrm{Nm}^{3} / \mathrm{h} / \mathrm{kg}$ was employed for the reaction and extended age of the EOR streams up to $24 \mathrm{~h}$. The experimental data depicted in Figure 4 demonstrateds that growth of the hydroxy ketal amine dimer impurity is significantly suppressed with 1.0 equiv. water $(<0.1 \%$ after $24 \mathrm{~h})$, and eliminated with 3.33 equiv. water $(14 \mathrm{~h})$. The isolated hydroxy indanone solids met all specifications with no negative impact to purity from the additional water.

\subsection{Scale and equipment dependency of the reduction-deprotection step}

Nitrogen sweep rate across the vessel headspace for the Reduction reaction was found as an important parameter to control the removal of $\mathrm{CO}_{2}$ from the system. This parameter will be scaled on a per-kg of keto ketal basis, independent of the headspace volume and vessel geometry. At the relatively low nitrogen flow rate ranges determined $\left(\leq 0.0275 \mathrm{Nm}^{3} / \mathrm{kg} / \mathrm{h}\right)$, turnover of the headspace gas is slow with respect to the rate of mass transfer of $\mathrm{CO}_{2}$, such that the $\mathrm{CO}_{2}$ approaches saturation in the headspace and remains relatively constant for the duration of the reaction. The $\mathrm{CO}_{2}$ removal 
rate is then determined primarily by the nitrogen flowrate into the headspace, and factors such as the headspace volume, vessel geometry and agitation rate would not have a significant impact on the removal rate of the dissolved $\mathrm{CO}_{2}$. Since the amount of $\mathrm{CO}_{2}$ being generated is determined by the batch size, the parameter may be scaled on an assay kg basis. To evaluate the risk posed by longer operation times in a production facility, the stability at various points during the process was evaluated. The Reduction EOR stream can be held at at $32{ }^{\circ} \mathrm{C}$ for at least $24 \mathrm{~h}$ with $\mathrm{N}_{2}$ sweep rate of $0.0175 \mathrm{Nm}^{3} / \mathrm{kg} / \mathrm{h}$ with no impact to quality. The Reduction EOR stream can be held at 32 ${ }^{\circ} \mathrm{C}$ for at least $56 \mathrm{~h}$ with no $\mathrm{N}_{2}$ sweep with no impact to quality. The Deprotection EOR stream can be held at $25^{\circ} \mathrm{C}$ for at least $21 \mathrm{~h}$ with no impact to quality. The crystallization slurry can be held at the target temperature for at least $20 \mathrm{~h}$ with no impact to quality. Both isolated wet and dry cake solids can be held at $60{ }^{\circ} \mathrm{C}$ for over 30 days with no impact to quality. Based on the data presented above and in previous sections, the quality of the isolated hydroxy indanone (3) is expected to meet the intermediate specifications upon changes in scale. Additionally, this step has already been run successfully at laboratory, pilot, and commercial scales, resulting in isolated product meeting all specifications at all scales.

\section{Process Modeling}

Calculation of Nitrogen Sweeping Factor

$$
S W F\left[\frac{N m^{3}}{k g * h r}\right]=\frac{\left(N_{2} \text { Flow }[N c f m] * 0.0283168\left[\frac{m^{3}}{f t^{3}}\right] * 60\left[\frac{m i n}{h r}\right]\right)}{\text { Diketone Batch Size }[\text { physical } k g]}
$$

Rationalization of Nitrogen Sweeping Factor. This normalized nitrogen flow is expected (and has been demonstrated) to produce scale-independent performance under two assumptions that are valid for the commercial manufacturing process: the total reactor volume is at least $10 \%$ headspace, and the volume of the reaction relative to the diketone basis does not significantly change batch-to-batch. The mechanistic effect of nitrogen flow is through the control of the dissolved concentration of $\mathrm{CO}_{2}$, a reaction byproduct which can reversibly inhibit the catalyst. If a consistent profile of $\mathrm{CO}_{2}$ concentration can be achieved across all scales, so will the reaction performance be consistent. Because this is achieved through the control of a headspace gas flow, 
a second phase, care must be taken that new scale sensitivities aren't introduced (i.e. through mass transfer effects).

A simple expression to describe the liquid-phase concentration of $\mathrm{CO}_{2}$, the key parameter to be controlled, is as follows:

$$
V_{L} \frac{d C_{\mathrm{CO}_{2}, \mathrm{~L}}}{d t}=-Q_{\mathrm{N}_{2}} C_{\mathrm{CO}_{2}, \mathrm{~V}}-k_{L} a\left(C_{\mathrm{CO}_{2}, \mathrm{~V}}-C_{\mathrm{CO}_{2}}^{*}\right)
$$

Where $\mathrm{V}_{\mathrm{L}}$ is the liquid volume of the reactor, $\mathrm{C}_{\mathrm{CO} 2, \mathrm{~L}}$ is the liquid-phase concentration of $\mathrm{CO}_{2}, \mathrm{Q}_{\mathrm{N} 2}$ is the volumetric flowrate of nitrogen, $\mathrm{C}_{\mathrm{CO} 2, \mathrm{~V}}$ is the vapor-phase concentration of $\mathrm{CO}_{2}, \mathrm{C}_{\mathrm{CO} 2}^{*}$ is the saturation concentration of $\mathrm{CO}_{2}$ in the vapor, and $\mathrm{k}_{\mathrm{L}}$ a is the mass-transfer coefficient for $\mathrm{CO}_{2}$ from liquid to vapor. A simple comparison of timescales will show that the left term of the expression's two terms, $\mathrm{CO}_{2}$ removal by headspace clearance, will dominate the behavior in this case.

The sweeping factors in this process are completely bounded by the range of $0.005-0.1 \mathrm{Nm}^{3} / \mathrm{kg}$ hr. The liquid volume for the reaction (acetonitrile, formic acid, triethylamine) is approximately 4.5 L/kg. If the reaction is operated in a vessel at $50 \%$ fill, then so also is the "headspace volume of the reaction" $4.5 \mathrm{~L} / \mathrm{kg}\left(0.0045 \mathrm{~m}^{3} / \mathrm{kg}\right)$. Therefore, vapor residence time (using the range of flowrates above) would be 5.4 minutes to $4.5 \mathrm{hr}$. Typical operation at $0.02 \mathrm{Nm}^{3} / \mathrm{kg}-\mathrm{hr}$ represents a vapor residence time of 13.5 minutes.

If we consider only the right-hand side of our previous expression, we can estimate the approach of vapor-phase concentration to equilibrium over that time. Based on our experience, a typical commercial-scale reactor vessel will have a $\mathrm{k}_{\mathrm{L}}$ a of $0.005-0.02 \mathrm{~s}^{-1}$. With these values, we can trivially produce the figure below which shows that a vapor-liquid mixture will reach more than $80 \%$ of saturation within 5 minutes, even for the slowest $\mathrm{k}_{\mathrm{L}}$ a values. Therefore, in our system, with a vapor residence time of minimally 5.4 minutes, we propose the assumption that our headspace is almost always saturated with $\mathrm{CO}_{2}$. 


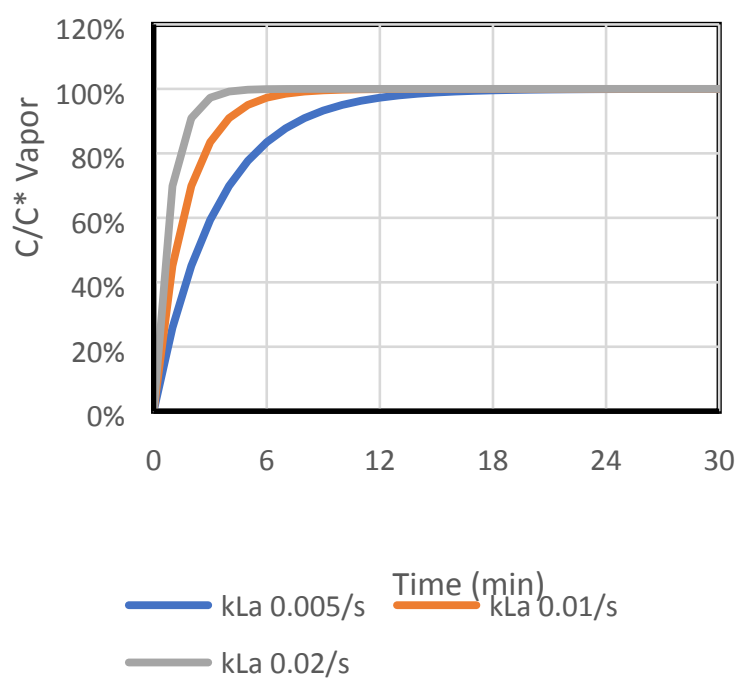

Figure S21. Process modeling of the kLa values for the vapor-liquid mixture.

Because the vapor residence time is so long relative to $\mathrm{k}_{\mathrm{L}} \mathrm{a}$, leading to a near-saturation steady state in the vapor, the removal of $\mathrm{CO}_{2}$ from the liquid phase is linear simply with the flowrate through the vapor - that is, the sweeping rate of the nitrogen. The right term, $\mathrm{C}_{\mathrm{CO} 2, \mathrm{~V}}-\mathrm{C}_{\mathrm{CO} 2}^{*}$ is close enough to zero to eliminate the effect of mass transfer.

These assumptions only break down when the vapor residence time is extremely low, such as when the reactor is operated quite full (greater than $90 \%$ ), or when the $\mathrm{k}_{\mathrm{L}} \mathrm{a}$ is extremely low such as with a still liquid surface. Since both are actively considered and easily avoided in the operation of this process at scale, these assumptions are considered strongly valid. Therefore, we propose that the control of dissolved $\mathrm{CO}_{2}$ with a nitrogen sweeping rate (normalized to batch volume with the basis mass as a surrogate) to be an appropriate and valid approach to scaling this reaction behavior.

Description of Nitrogen Flow Simulations. Process modeling software, DynoChem 5, was used to simulate the dynamics of this system. Two phases are modeled, Solution and Headspace. In the Solution phase, a $0^{\text {th }}$ order reaction is estimated with a rate constant $\mathrm{k}_{\text {ref }}(35 \mathrm{C})=2 \mathrm{e}-5 \mathrm{M}^{-1} \mathrm{~s}^{-1}$ to simulate the typical behavior of this reaction, which is approximately solubility-limited with a half-life of 3.5 hours. This reaction is used to simulate the slow release of $\mathrm{CO}_{2}$ as a byproduct of the reaction. The Solution phase is initialized with reactants in concentration according to our process description. 
The Headspace phase is initialized to be filled with nitrogen, according to the specified pressure and temperature, inherited from the liquid phase temperature. A feed flow of nitrogen is provided to the Headspace phase based on a specified sweeping factor. A mass-transfer statement is included to simulate the movement of $\mathrm{CO}_{2}$ from the Solution to Headspace phase with a $\mathrm{k}_{\mathrm{L}} \mathrm{a}$ of $0.01 \mathrm{~s}^{-1}$. A temperature-modified Henry's law is used as the phase equation to calculate saturation concentration at different temperatures:

$$
H(T)=H_{r e f}\left(T_{r e f}\right) \exp \left(-A *\left(\frac{1}{T}-\frac{1}{T_{r e f}}\right)\right)
$$

Where $H(T)$ is the Henry's coefficient at temperature T, $H_{\text {ref }}$ is the reference Henry's coefficient at temperature $\mathrm{T}_{\text {ref }}$ and $\mathrm{A}$ is the temperature-scaling parameter related to enthalpy of dissolution. Aspen property analysis was used to collect VLE data in our temperature and pressure ranges. The equation above was then used to fit the parameters $\mathrm{H}_{\text {ref }}\left(\mathrm{T}_{\text {ref }}\right)$ and A against this data. The results were as follows:

$$
\begin{aligned}
\mathrm{H}_{\text {ref }}(35 \mathrm{C}) & =225.038 \mathrm{~Pa}-\mathrm{m}^{3} / \mathrm{mol} \\
\mathrm{A} & =1028.4 \mathrm{~K}
\end{aligned}
$$

Also in the Headspace phase, in response to the inlet flow and mass transfer terms, a venting flowrate is used to maintain a constant headspace volume, at a constant pressure. This vent flowrate is determined by a simulated PI controller to maintain these setpoints. This is simply a modeling nuance related to the use of DynoChem; the actual headspace volume and pressure control is of course achieved by physical vessel walls and pressure relief valves in the plant. With the Headspace and Solution phases defined and initialized as described above, we can perform various simulations to observe the effect of many factors on the profile of dissolved $\mathrm{CO}_{2}$ concentration during the reaction (e.g. ratio of headspace to liquid volume, pressure, temperature, sweeping rate). 


\section{Process Safety}

All measurements were taken using an Agilent 490 Micro GC System with 10m MS5A column with heated injector, TCD detector, and argon carrier gas. The injector was heated to $50{ }^{\circ} \mathrm{C}$, with an injection time of $40 \mathrm{~ms}$, backflush of $10 \mathrm{~s}$, and column temperature of $40^{\circ} \mathrm{C}$. Samples $(5 \mathrm{~mL})$ were injected using a Harvard syringe pump to ensure consistent injection volume.

Table S17. GC analysis of hydrogen.

\begin{tabular}{|c|c|c|c|c|c|}
\hline Sample & Label & Sample description & Retention time (s) & Area counts & $\begin{array}{c}\text { \% } \\
\text { Hydrogen }\end{array}$ \\
\hline 1 & S\#1R\#1 & $\begin{array}{c}\text { Reduction } \\
\text { headspace - 3 h }\end{array}$ & 25.86 & 19891359 & 11.90 \\
\hline 2 & S\#2R\#1 & $\begin{array}{c}\text { Reduction } \\
\text { headspace - 6 h }\end{array}$ & 26.12 & 36856236 & 22.05 \\
\hline 3 & SOR 158-19-2 & $\begin{array}{c}\text { MMC scan } \\
\text { headspace }\end{array}$ & 27.2 & 64050935 & 38.32 \\
\hline
\end{tabular}

GC Calibration curve for Hydrogen

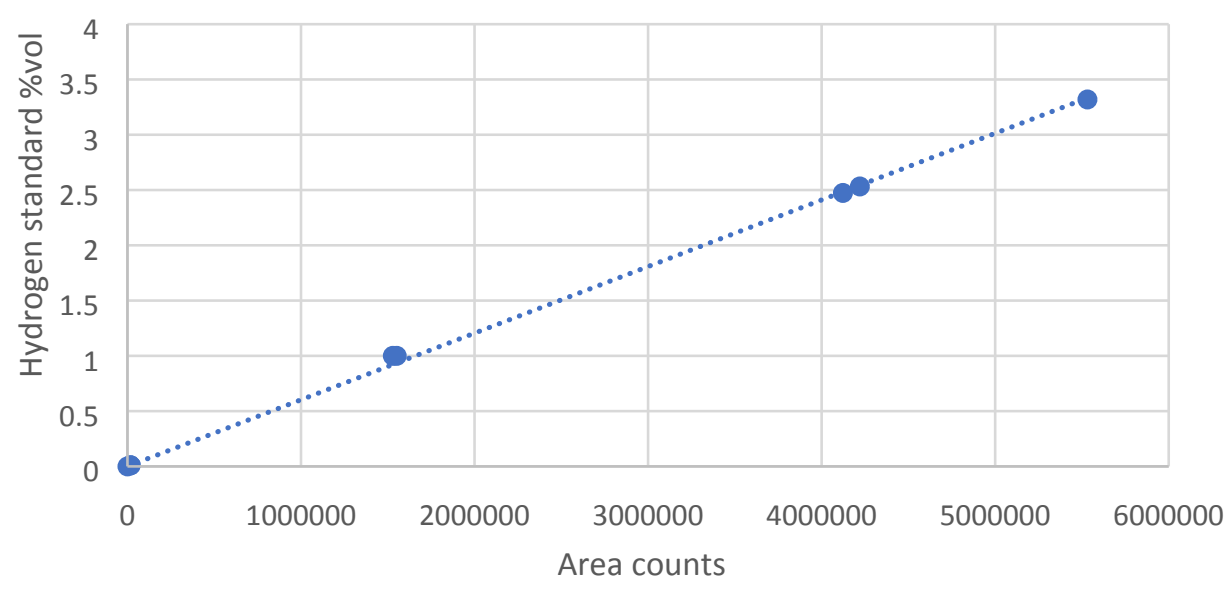


Method Name: C: MicroGCLPSELMethod 20191118glp w 8sec BF.met

Data: C: $\quad$ MicroGCIEPSE Result 6482 Reduction EOR (NB-0007) $8 \mathrm{sec}$ S\#1 R\#1.dat

User: SYSTEM (SYSTEM)

Acquired: $\quad 2 / 11 / 20202: 01: 10$ PM (GMT $-05: 00)$

Printed: $\quad$ 2/11/2020 2:04:08 PM (GMT -05:00)

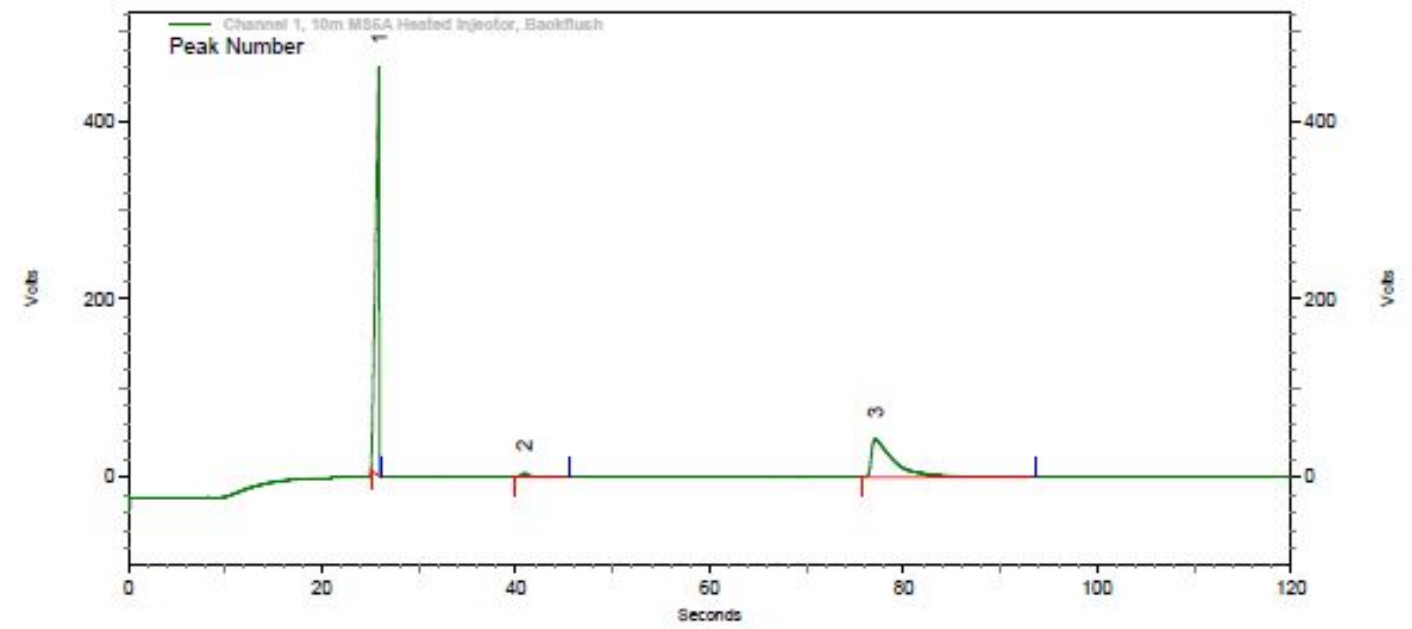

\begin{tabular}{|c|c|c|c|}
\hline $\begin{array}{r}\text { Channel 1, 10m MS5A } \\
\text { Heated Injector, } \\
\text { Backflush Results } \\
\text { Peak \# }\end{array}$ & Retention Time & Area & Area Percent \\
\hline 1 & 25.860 & 19891359 & 63.063 \\
\hline 2 & 40.880 & 369062 & 1.170 \\
\hline 3 & 77.100 & 11281586 & 35.767 \\
\hline \multicolumn{4}{|l|}{ Totals } \\
\hline & & 31542007 & 100.000 \\
\hline
\end{tabular}

Figure S22. GC spectrum for sample 1. 
Method Name: C:LicroGCLPSELMethod 20191118glp w 8sec BF.met

Data: C: $\quad$ MicroGC EPSE Result 6482 Reduction EOR (NB-0007) $8 \mathrm{sec}$ S\#2 R\#1.dat

User: SYSTEM (SYSTEM)

Acquired: $\quad 2 / 11 / 20202: 08: 47$ PM (GMT -05:00)

Printed: $\quad$ 2/11/2020 2:11:31 PM (GMT -05:00)

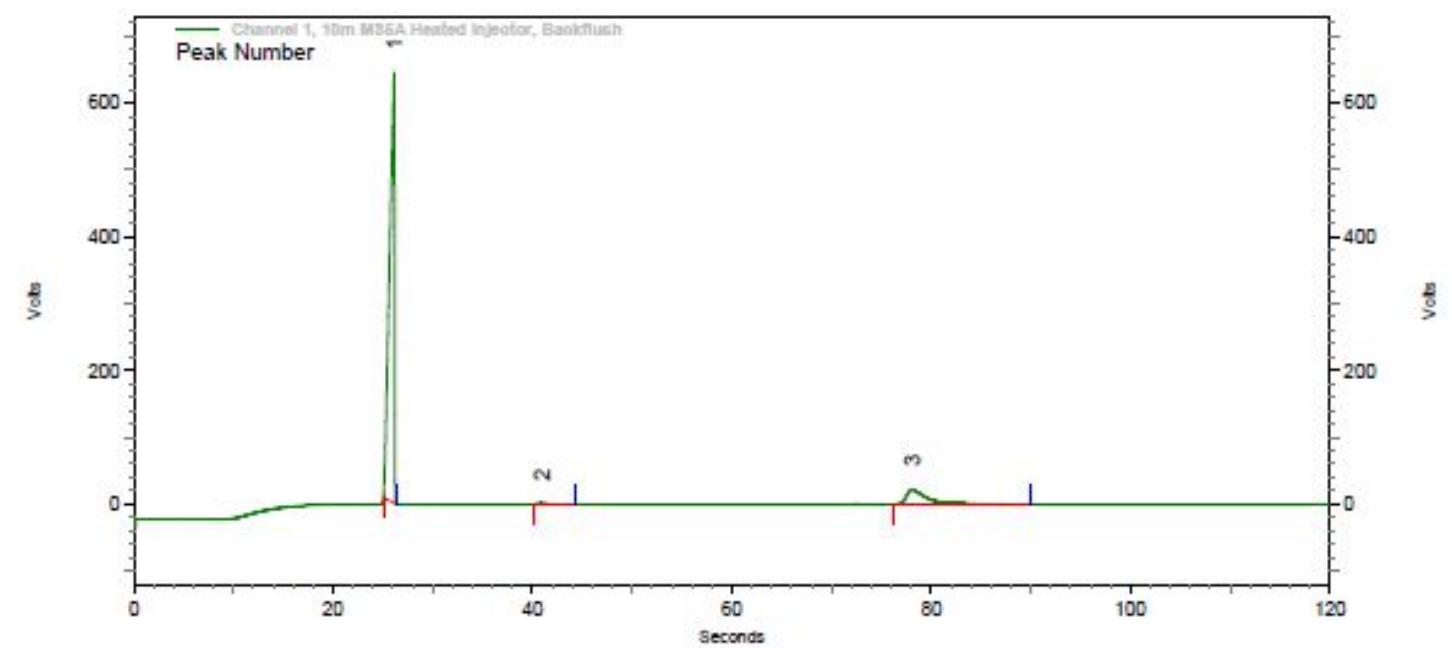

Channel 1, 10m MS5A

Heated Injector,

Backflush Results

Peak \#

Retention Time

26.120

40.940

78.080

Area
36856236
89570
4980580

Area Percent

87.907

0.214

3

11.879

Totals

Figure S23. GC spectrum for sample 2. 


\section{Area \% Report}

Data File: $\quad$ C:LMicroGCLEPSE Result $M M K-6482$ Step4 SOR 158-19-2.dat

Method: $\quad$ C:LMicroGClEPSELMethod 20191118glp.met

Acquired: $\quad 1 / 24 / 2020$ 2:10:13 PM (GMT -05:00)

Printed: $\quad$ 1/24/2020 2:16:57 PM (GMT -05:00)

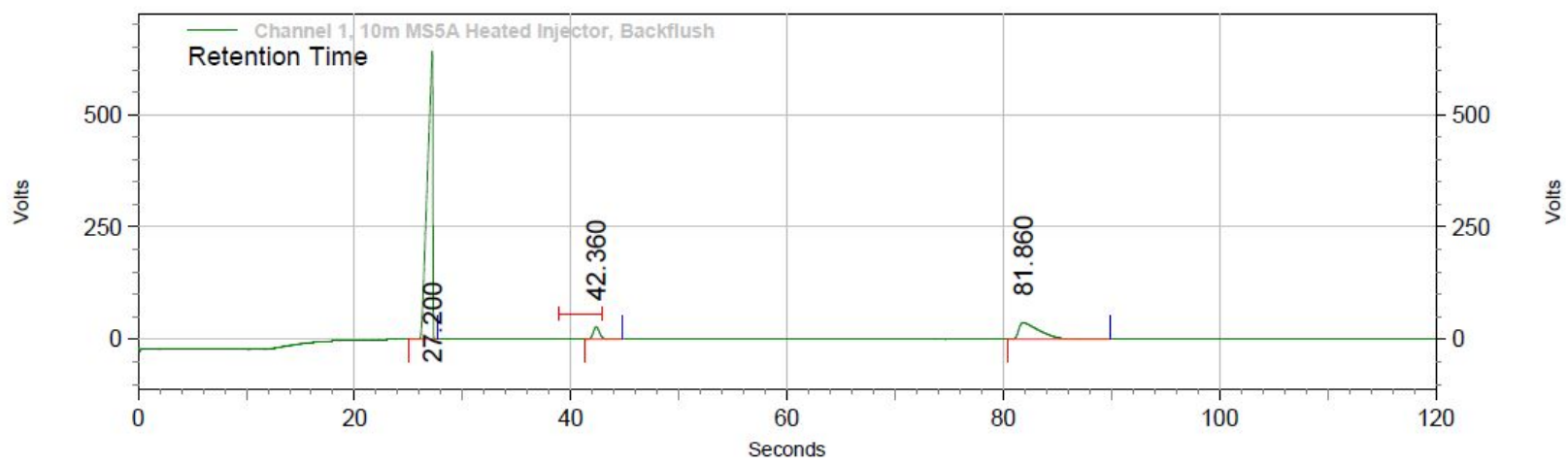

Channel 1, 10m

MS5A Heated

Injector,

Backflush Results

Retention Time

27.200

42.360

81.860

Area

Area \%

Height

Height \%

37186998

79.11

64050935

90.88

1828459

2755526

3.91

Totals

$17.00 \quad 3673130$

5.21

7988752

17.00

47004209

100.00

70479591

100.00

Figure S24. GC spectrum for sample 3. 


\section{Analytical Procedures}

\subsection{Form characterization data for hydroxy indanone 3}

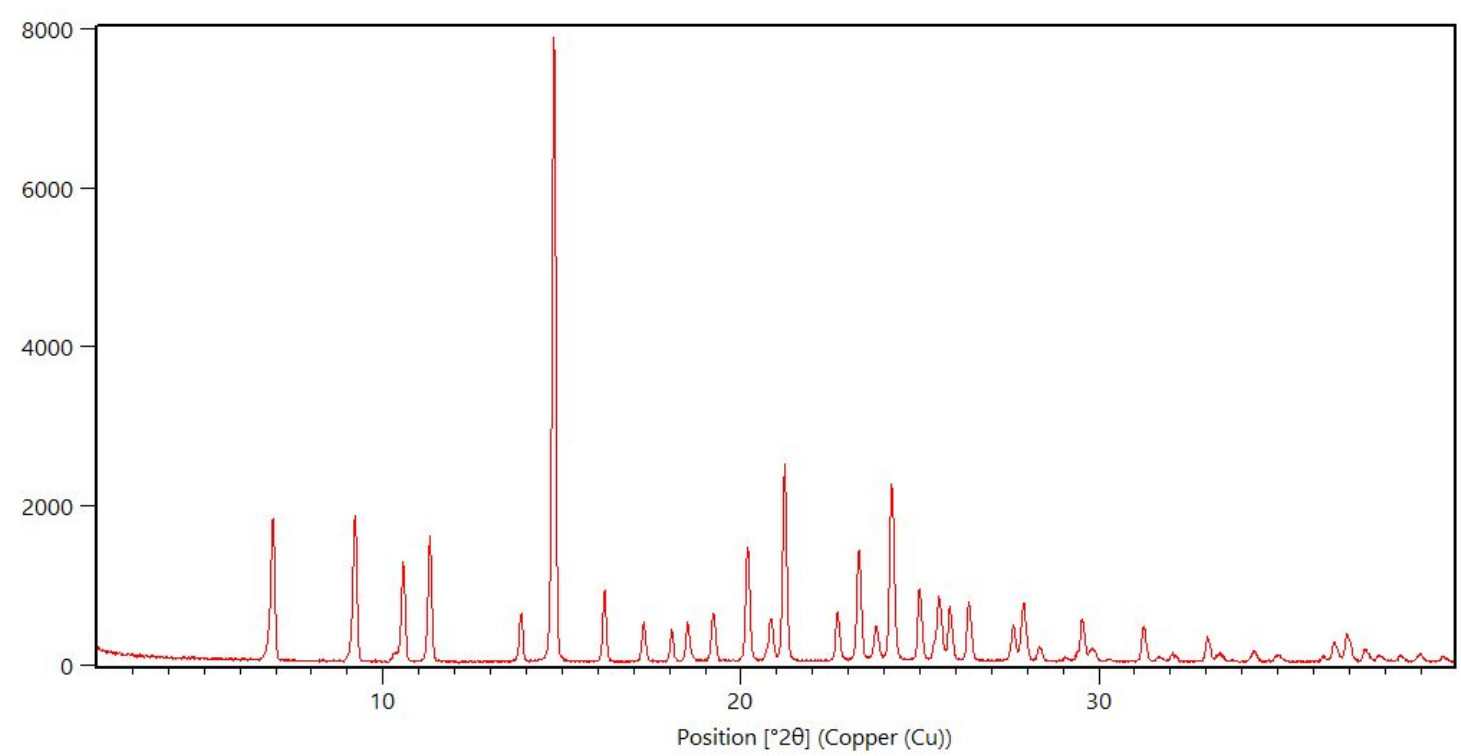

Figure S25. XRPD spectrum of 3 (form 1).

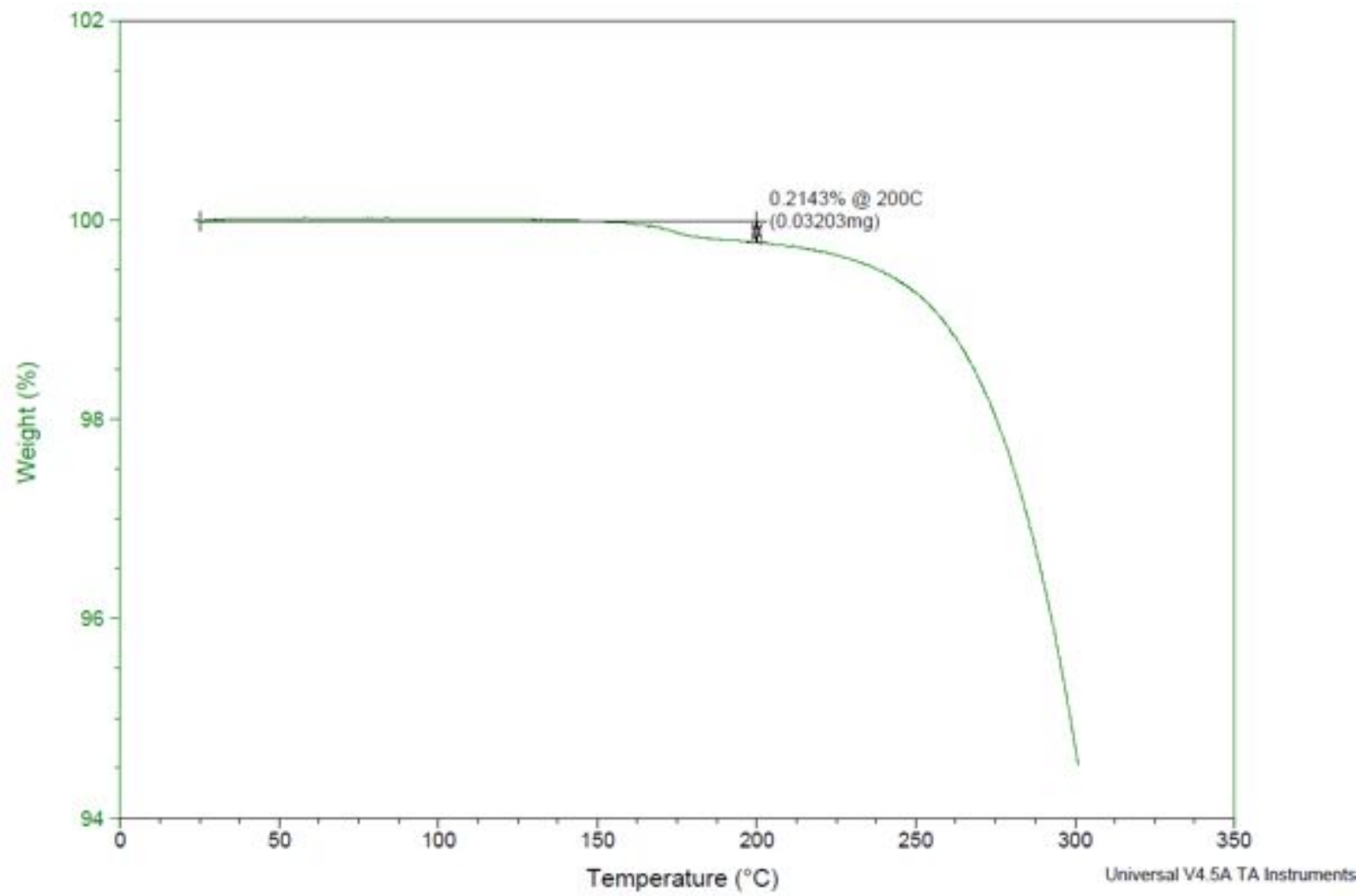

Figure S26. TGA data for compound 3 (form 1). 


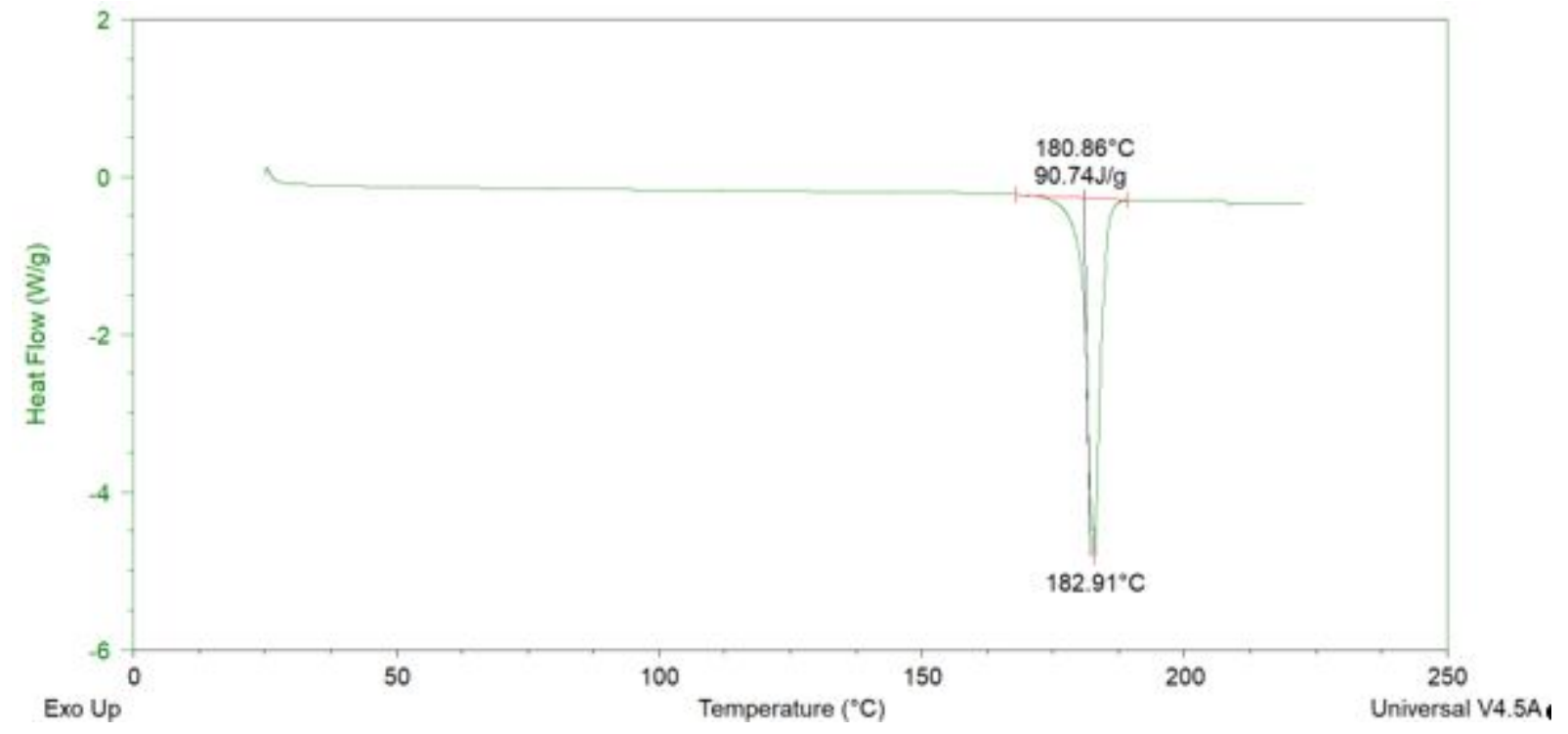

Figure S27. DSC data for compound 3 (form 1).

\subsection{Identity by IR}

The sample was placed on an ATR-FTIR sampling device and recorded thr infrared spectrum of 3 using a suitable FTIR spectrometer. The spectrum should be similar to that of a reference spectrum.

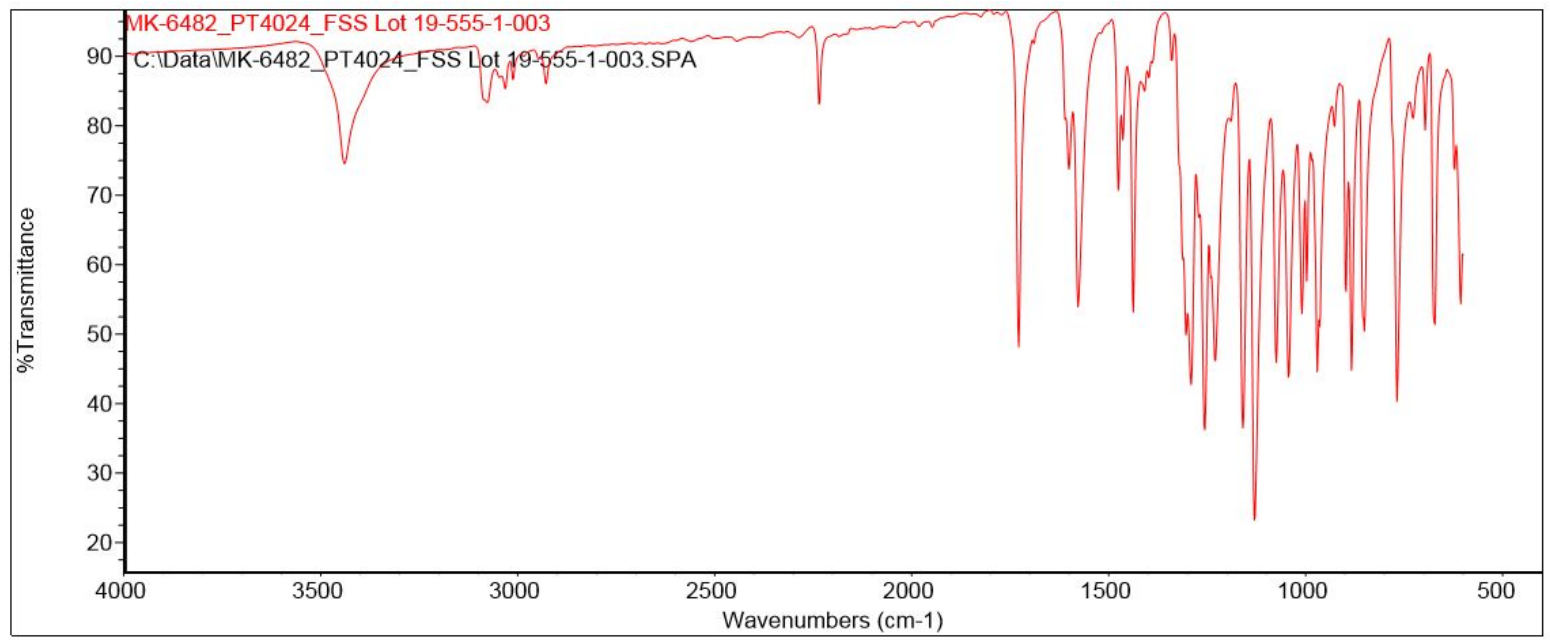

Figure S28. Representative Infrared Spectrum. 


\subsection{HPLC/UPLC method}

Table S18. Chromatographic conditions.

\begin{tabular}{|c|c|c|c|}
\hline Column & \multicolumn{3}{|c|}{$\begin{array}{l}\text { Waters BEH C18, } 100 \mathrm{~mm} \times 2.1 \mathrm{~mm} \text { I.D., } 1.7 \mu \mathrm{m} \text { or } \\
\text { equivalent }(\mathrm{P} / \mathrm{N}: 186002352)\end{array}$} \\
\hline Column Temperature & \multicolumn{3}{|l|}{$50^{\circ} \mathrm{C}$} \\
\hline Flow Rate & \multicolumn{3}{|l|}{$0.4 \mathrm{~mL} / \mathrm{min}$} \\
\hline Detector & \multicolumn{3}{|l|}{$\mathrm{UV}$ at $230 \mathrm{~nm}$} \\
\hline Diluent & \multicolumn{3}{|c|}{ Water/Acetonitrile, 50/50, v/v } \\
\hline \multirow[t]{7}{*}{ Gradient Program } & Time (minute) & $\% \mathrm{~A}$ & B\% \\
\hline & 0 & 85 & 15 \\
\hline & 20 & 45 & 55 \\
\hline & 24 & 15 & 85 \\
\hline & 26 & 15 & 85 \\
\hline & 27 & 85 & 15 \\
\hline & 31 & 85 & 15 \\
\hline Mobile Phase A & \multicolumn{3}{|c|}{$\begin{array}{l}7 \mathrm{mM} \text { Potassium phosphate dibasic }+3 \mathrm{mM} \text { Potassium } \\
\text { phosphate monobasic buffer }\end{array}$} \\
\hline Mobile Phase B & \multicolumn{3}{|l|}{ Acetonitrile } \\
\hline
\end{tabular}

Table S19. Chromatographic conditions for chiral purity by UPLC.

\begin{tabular}{|c|c|c|c|}
\hline Column & \multicolumn{3}{|c|}{$\begin{array}{l}\text { Daicel CHIRALCEL® OZ-3R, } 150 \mathrm{~mm} \text { x } 4.6 \mathrm{~mm} \text { I.D., } 3 \mu \mathrm{m} \text { (or } \\
\text { equivalent) PN: } 42824\end{array}$} \\
\hline Column Temperature & \multicolumn{3}{|l|}{$40^{\circ} \mathrm{C}$} \\
\hline Flow Rate & \multicolumn{3}{|l|}{$1.2 \mathrm{~mL} / \mathrm{min}$} \\
\hline Detector & \multicolumn{3}{|l|}{$\mathrm{UV}$ at $220 \mathrm{~nm}$} \\
\hline Sample Concentration & \multicolumn{3}{|l|}{$0.6 \mathrm{mg} / \mathrm{mL}$} \\
\hline Diluent & \multicolumn{3}{|c|}{ Water/Acetonitrile, $10 / 90, \mathrm{v} / \mathrm{v}$} \\
\hline Mobile Phase A & \multicolumn{3}{|c|}{$0.1 \%(\mathrm{v} / \mathrm{v}) \mathrm{H}_{3} \mathrm{PO}_{4}$ in Water } \\
\hline Mobile Phase B & \multicolumn{3}{|l|}{ Acetonitrile } \\
\hline \multirow[t]{7}{*}{ Gradient Program } & Time (minute) & $\% \mathrm{~A}$ & $\mathrm{~B} \%$ \\
\hline & 0 & 70 & 30 \\
\hline & 7 & 70 & 30 \\
\hline & 10 & 5 & 95 \\
\hline & 12 & 5 & 95 \\
\hline & 12.1 & 70 & 30 \\
\hline & 16 & 70 & 30 \\
\hline
\end{tabular}




\subsection{GC and IC methods}

Table S20. Chromatographic conditions for GC

\begin{tabular}{|l|l|}
\hline \hline Column & $\begin{array}{l}\text { JW Scientific DB-1 (100 \% dimethyl polysiloxane); } 30 \mathrm{~m} \text { length } \\
\text { x } 0.53 \mathrm{~mm} \text { ID x } 3 \mu \mathrm{m} \text { film. (P/N : 125-1034) }\end{array}$ \\
\hline Carrier Gas: & Helium \\
\hline Column Flowrate: & Constant Flow, $6.0 \mathrm{~mL} / \mathrm{min}$ \\
\hline Temperature Program: & $45^{\circ} \mathrm{C}$ for $3.0 \mathrm{~min}$ hold; $45^{\circ} \mathrm{C} / \mathrm{min}$ to $250^{\circ} \mathrm{C}, 3.0 \mathrm{~min}$ hold; \\
\hline Total Run Time & Approximately $10.6 \mathrm{~min}$ \\
\hline Injection Volume: & $1 \mu \mathrm{L}$ \\
\hline Injector: & $160^{\circ} \mathrm{C}$; Split $10: 1$ \\
\hline Detector Parameters & $\begin{array}{l}\text { Type:Flame Ionization }(\mathrm{FID}) \\
\text { Detector Temp.: } 260^{\circ} \mathrm{C}\end{array}$ \\
\hline Makeup (He) flow & $30 \mathrm{~mL} / \mathrm{min}$ \\
\hline $\mathrm{H}_{2}$ flow & $40 \mathrm{~mL} / \mathrm{min}$ \\
\hline Air flow & $400 \mathrm{~mL} / \mathrm{min}$ \\
\hline Sample Concentration & $30.0 \mathrm{mg} / \mathrm{mL}$ \\
\hline$\dagger$ I.D. $=$ Inner Diameter & \\
\hline \hline
\end{tabular}

Table S21. Chromatographic conditions for IC for measuring the chloride content.

\begin{tabular}{|c|c|c|}
\hline Column & \multicolumn{2}{|c|}{ 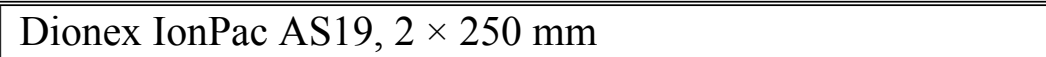 } \\
\hline Guard Column & \multicolumn{2}{|c|}{ Dionex IonPac AS19-4 $\mu \mathrm{m}, 2 \times 50 \mathrm{~mm}$} \\
\hline Column Temperature & \multicolumn{2}{|l|}{$30^{\circ} \mathrm{C}$} \\
\hline Cell Temperature & \multicolumn{2}{|l|}{$35^{\circ} \mathrm{C}$} \\
\hline Detection mode & \multicolumn{2}{|l|}{ Conductivity } \\
\hline AERS-4mm Suppressor & \multicolumn{2}{|l|}{$50 \mathrm{~mA}$} \\
\hline Eluent & \multicolumn{2}{|c|}{ Dionex EGC $500 \mathrm{KOH}$} \\
\hline \multirow{7}{*}{ Gradient Program } & Time & Eluent Concentration (mM) \\
\hline & 0 & 2 \\
\hline & 5 & 2 \\
\hline & 14 & 50 \\
\hline & 16 & 50 \\
\hline & 17 & 2 \\
\hline & 25 & 2 \\
\hline Flow Rate & \multicolumn{2}{|l|}{$0.4 \mathrm{~mL} / \mathrm{min}$} \\
\hline Sample Concentration & \multicolumn{2}{|l|}{$2.0 \mathrm{mg} / \mathrm{mL}$} \\
\hline Injection Volume & \multicolumn{2}{|l|}{$5 \mu \mathrm{L}$} \\
\hline Run Time & \multicolumn{2}{|l|}{$25 \mathrm{~min}$} \\
\hline
\end{tabular}




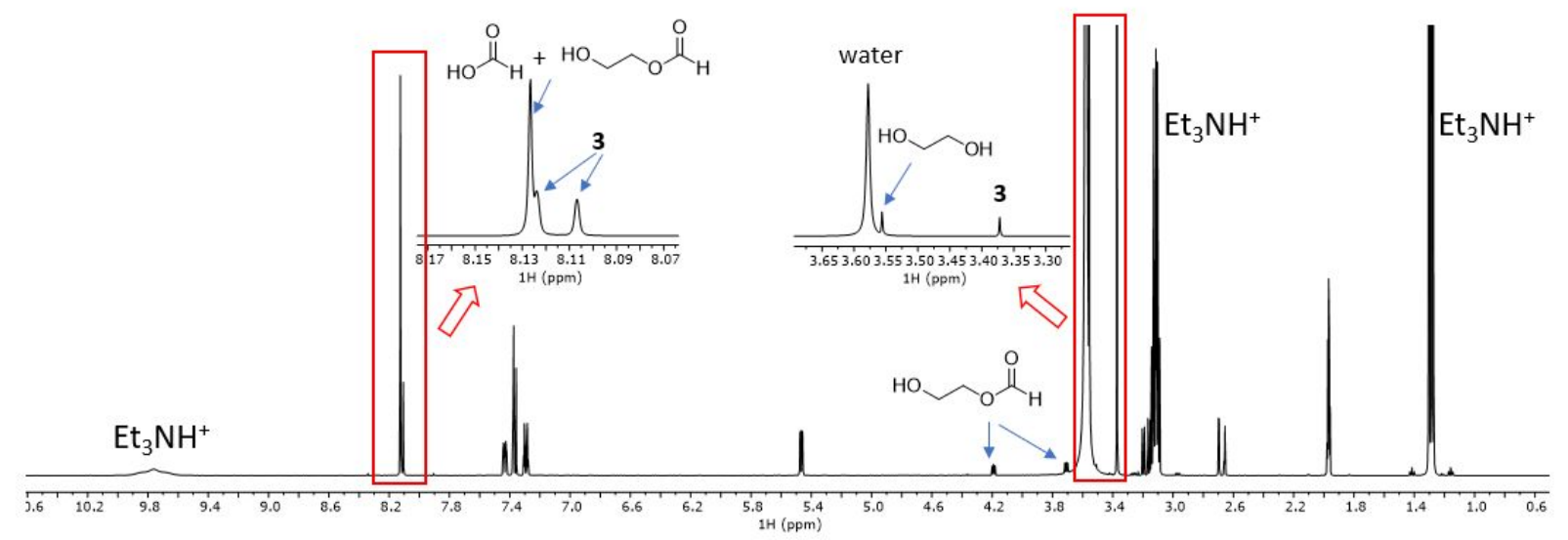

Figure S29. Crude EOR analysis by $\mathrm{HNMR}$ in $\mathrm{CD}_{3} \mathrm{CN}$.

\section{3-fluoro-5-((7-(methylsulfonyl)-3-oxo-2,3-dihydrospiro[indene-1,2'-[1,3]dioxolan]-4- yl)oxy)benzonitrile (X)}

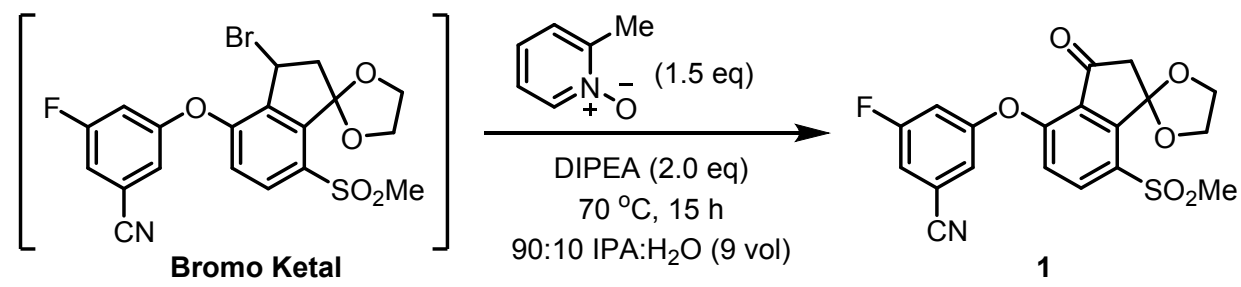

DIPEA (41 mL, 2.0 equiv) and 2-picoline N-oxide (33 g, $57.9 \mathrm{wt} \%$ in $\mathrm{MeCN}, 1.5$ equiv) were charged to the crude quenched solution of bromo ketal starting material, and the resulting dark homogeneous solution was aged at $72{ }^{\circ} \mathrm{C}$ until full consumption the (typically $15-18 \mathrm{~h}$ ). The reaction mixture was cooled to $40{ }^{\circ} \mathrm{C}$ and concentrated under vacuum to $\sim 1.0 \mathrm{~L}$. The batch was seeded with $1.0 \mathrm{~g}(2.0 \mathrm{wt} \%)$ of ketone 1 . After aging for $20 \mathrm{~min}$ at $40^{\circ} \mathrm{C}$, the batch was further concentrated under vacuum to $\sim 400 \mathrm{~mL}$ at $40{ }^{\circ} \mathrm{C} .90: 10$ IPA: $\mathrm{H}_{2} \mathrm{O}(450 \mathrm{~mL}, 9$ vol) was charged to the batch at $40{ }^{\circ} \mathrm{C}$ while solvent was continuously removed via vacuum distillation. The batch volume was maintained between $350-450 \mathrm{~mL}$ throughout the anti-solvent addition. After the complete addition of the anti-solvent, the solvent ratio was determined to be 3.9:1 IPA:MeCN (v/v) by ${ }^{1} \mathrm{H}$ NMR. The batch was cooled to $25^{\circ} \mathrm{C}$ and aged at $25^{\circ} \mathrm{C}$ for $15 \mathrm{~h}$. The resulting slurry was filtered, and the cake was slurry washed four times with 2:8 MeCN:IPA $(150 \mathrm{~mL})$. After 
drying under vacuum and $\mathrm{N}_{2}$ at $50{ }^{\circ} \mathrm{C}$, the desired Keto Ketal 1 (35.3 g, $97.6 \mathrm{wt} \%, 87.5 \mathrm{mmol}$, $73 \%$ over 2 steps) was isolated as a light brown crystalline solid: ${ }^{1} \mathrm{H}$ NMR $\left(500 \mathrm{MHz}, \mathrm{CDCl}_{3}\right): \delta$ (ppm) $8.38(\mathrm{~d}, J=8.6 \mathrm{~Hz}, 1 \mathrm{H}), 7.24$ (ddd, $J=7.6,2.3,1.3 \mathrm{~Hz}, 1 \mathrm{H}), 7.15(\mathrm{dd}, J=2.1,1.0 \mathrm{~Hz}, 1 \mathrm{H})$, $7.10(\mathrm{~d}, J=8.6 \mathrm{~Hz}, 1 \mathrm{H}), 7.07(\mathrm{dt}, J=9.0,2.3 \mathrm{~Hz}, 1 \mathrm{H}), 4.51-4.41(\mathrm{~m}, 2 \mathrm{H}), 4.18-4.08(\mathrm{~m}, 2 \mathrm{H})$, 3.27 (s, 3H), $2.94(\mathrm{~s}, 2 \mathrm{H}) .{ }^{13} \mathrm{C}$ NMR (126 MHz, $\left.\mathrm{CDCl}_{3}\right): \delta(\mathrm{ppm}) 195.58,163.25(\mathrm{~d}, J=253.1 \mathrm{~Hz})$, $156.93(\mathrm{~d}, J=11.1 \mathrm{~Hz}), 156.27,151.48,139.81,134.66,129.49,120.15,118.95$ (d, $J=3.7 \mathrm{~Hz})$, $116.73(\mathrm{~d}, J=3.6 \mathrm{~Hz}), 116.06(\mathrm{~d}, J=24.8 \mathrm{~Hz}), 115.12(\mathrm{~d}, J=11.4 \mathrm{~Hz}), 112.61(\mathrm{~d}, J=24.4 \mathrm{~Hz})$, 109.79, 66.07, 50.28, 45.14 ${ }^{19} \mathrm{~F}$ NMR (471 MHz, $\left.\mathrm{CDCl}_{3}\right): \delta(\mathrm{ppm})-105.62 . \mathrm{HRMS}: \mathrm{m} / \mathrm{z}$ calculated for $\mathrm{C}_{19} \mathrm{H}_{14} \mathrm{O}_{6} \mathrm{NFSH}:[\mathrm{M}+\mathrm{H}]^{+}, 404.0604$, found: $404.0603[\mathrm{M}+\mathrm{H}]^{+}$.

\section{(R)-3-fluoro-5-((3-hydroxy-7-(methylsulfonyl)-1-oxo-2,3-dihydro-1H-inden-4- yl)oxy)benzonitrile(X)}

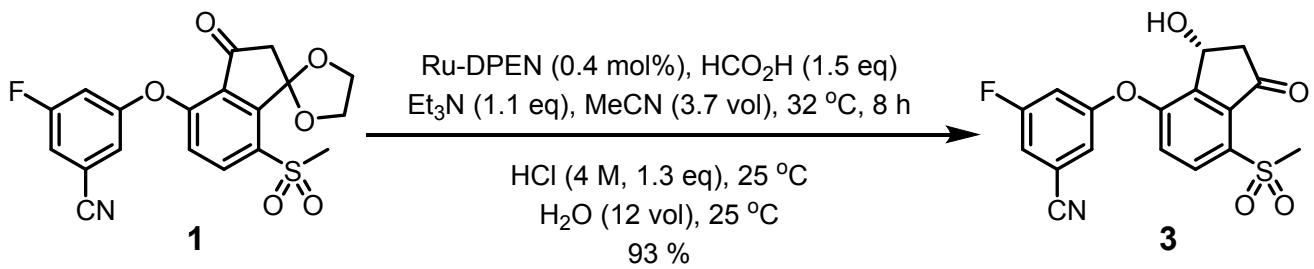

To a jacketed reactor connected to the scrubber and $\mathrm{N}_{2}$ line, $\mathrm{MeCN}$ (111.0 mL, $3.15 \mathrm{vol}$ ) was charged. Next, Keto Ketal starting material 1 (30.0 g, $96.6 \mathrm{wt} \%, 1.0 \mathrm{eq})$ was added to the vessel at $15-25^{\circ} \mathrm{C}$, followed by the addition of $\mathrm{Et}_{3} \mathrm{~N}(8.0 \mathrm{~g}, 1.1 \mathrm{eq})$. Then formic acid (4.96 g, $\left.1.5 \mathrm{eq}\right)$ was charged to the reaction mixture slowly while agitating at $230 \mathrm{rpm}$, and maintaining the temperature between $10-15^{\circ} \mathrm{C}$. To this mixture, the Ru-DPEN catalyst (183 mg, $99.9 \mathrm{wt} \%, 0.004$ eq.) was added as a solution in $\mathrm{MeCN}(10.5 \mathrm{~mL}, 0.35 \mathrm{vol})$. The slurry mixture was heated at $30-35^{\circ} \mathrm{C}$ with $8.75 \mathrm{~mL} / \mathrm{min} \mathrm{N}_{2}$ sweeping rate for 5 to 10 hours until completion to generate the desired Hydroxy Ketal intermediate. The crude stream was taken to the next step without any purification. The temperature of the batch was decreased to $20-25^{\circ} \mathrm{C}$. To the reactor, $\mathrm{HCl}(22.4 \mathrm{~mL}, 4.18 \mathrm{M}, 1.3$ eq) was charged slowly while maintaining the reaction mixture's temperature between $20-25{ }^{\circ} \mathrm{C}$. The batch was aged at $20-25{ }^{\circ} \mathrm{C}$ for 5-10 hours until completion to generate product 2 . Next, water (30.0 mL, $1.0 \mathrm{vol})$ was added followed by addition of Hydroxy Indanone 3 seed (300 mg, $1 \mathrm{wt} \%)$ to the reactor over $20 \mathrm{~min}$ at $20-25^{\circ} \mathrm{C}$ to afford a white slurry. Additional amount of water (360.0 
$\mathrm{mL}, 11$ vol) was added over 7-9 hours, which was then filtered and washed twice with water (105 $\mathrm{mL}, 3 \mathrm{vol})$, and once with IPA ( $105 \mathrm{~mL}, 3 \mathrm{vol})$. The cake was dried under nitrogen and vacuum to afford the Hydroxy Indanone 3 as a white crystalline solid in 93\% isolated yield.

Hydroxy ketal intermediate 2: ${ }^{1} \mathrm{H}$ NMR $\left(500 \mathrm{MHz}, \mathrm{CD}_{3} \mathrm{CN}\right): \delta(\mathrm{ppm}) 8.00(\mathrm{~d}, \mathrm{~J}=10.0 \mathrm{~Hz}, 1 \mathrm{H})$, $7.36(\mathrm{~d}, \mathrm{~J}=5.0 \mathrm{~Hz}, 1 \mathrm{H}), 7.30(\mathrm{~s}, 1 \mathrm{H}), 7.20(\mathrm{~d}, \mathrm{~J}=10.0 \mathrm{~Hz}, 1 \mathrm{H}), 7.10(\mathrm{~d}, \mathrm{~J}=10.0 \mathrm{~Hz}, 1 \mathrm{H}), 5.21$ $(\mathrm{m}, 1 \mathrm{H}), 4.25(\mathrm{~m}, 2 \mathrm{H}), 4.05(\mathrm{~m}, 2 \mathrm{H}), 3.51(\mathrm{~d}, \mathrm{~J}=10.0 \mathrm{~Hz}, 1 \mathrm{H}), 3.21(\mathrm{~s}, 3 \mathrm{H}), 2.61(\mathrm{dd}, \mathrm{J}=15.0 \mathrm{~Hz}$, $\mathrm{J}=5.0 \mathrm{~Hz}, 1 \mathrm{H}), 2.12(\mathrm{dd}, \mathrm{J}=10.0 \mathrm{~Hz}, \mathrm{~J}=5.0 \mathrm{~Hz}, 1 \mathrm{H}) .{ }^{13} \mathrm{C} \mathrm{NMR}\left(126 \mathrm{MHz}, \mathrm{CD}_{3} \mathrm{CN}\right): \delta(\mathrm{ppm})$ $163.02(\mathrm{~d}, \mathrm{~J}=248.2 \mathrm{~Hz}), 157.80(\mathrm{~d}, \mathrm{~J}=11.3 \mathrm{~Hz}), 156.85,142.48,138.96,133.71,133.62,119.64$, $119.22(\mathrm{~d}, \mathrm{~J}=3.8 \mathrm{~Hz}), 115.02,115.11(\mathrm{~d}, \mathrm{~J}=26.5 \mathrm{~Hz}), 115.09,114.31$ (d, J = 11.3 Hz), 112.20 (d, $\mathrm{J}=23.9 \mathrm{~Hz}), 68.18,65.46,65.10,47.24,44.40 .{ }^{19} \mathrm{~F}$ NMR (471 MHz, $\left.\mathrm{CD}_{3} \mathrm{CN}\right): \delta(\mathrm{ppm})-109.32$. HRMS: $\mathrm{m} / \mathrm{z}$ calcd for $\mathrm{C}_{19} \mathrm{H}_{16} \mathrm{O}_{6} \mathrm{NFSNa}(\mathrm{M}+\mathrm{Na}+), 428.0580$, Found: $428.0576(\mathrm{M}+\mathrm{Na}+)$.

Hydroxy Indanone product 3: ${ }^{1} \mathrm{H}$ NMR $\left(500 \mathrm{MHz}, \mathrm{CD}_{3} \mathrm{CN}\right): \delta(\mathrm{ppm}) 8.10(\mathrm{~d}, \mathrm{~J}=10.0 \mathrm{~Hz}, 1 \mathrm{H})$, $7.40(\mathrm{~d}, \mathrm{~J}=5.0 \mathrm{~Hz}, 1 \mathrm{H}), 7.33(\mathrm{~m}, 2 \mathrm{H}), 7.24(\mathrm{~d}, \mathrm{~J}=10.0 \mathrm{~Hz}, 1 \mathrm{H}), 5.42(\mathrm{~m}, 1 \mathrm{H}), 3.85(\mathrm{~d}, \mathrm{~J}=6.0 \mathrm{~Hz}$, 1H), 3.34 (s, 3H), 3.14 (dd, J = 20.0 Hz, J = 5.0 Hz, 1H), 2.62 (dd, J = 15.0 Hz, J = 10.0 Hz, 1H). ${ }^{13} \mathrm{C}$ NMR (126 MHz, $\left.\mathrm{CD}_{3} \mathrm{CN}\right): \delta(\mathrm{ppm}) 200.44,163.1(\mathrm{~d}, \mathrm{~J}=248.8 \mathrm{~Hz}), 157.83,157.45(\mathrm{~d}, \mathrm{~J}=$ $11.5 \mathrm{~Hz}$ ), 148.41, 136.08, 133.14, 132.46, 123.44, 119.30 (d, J = 3.6 Hz), 115.50 (d, J = 25.4 Hz), $114.50(\mathrm{~d}, \mathrm{~J}=12.0 \mathrm{~Hz}), 112.40(\mathrm{~d}, \mathrm{~J}=24.9 \mathrm{~Hz}), 64.89,46.63,42.54 .{ }^{19} \mathrm{~F} N \mathrm{NR}\left(471 \mathrm{MHz}, \mathrm{CD}_{3} \mathrm{CN}\right)$ : $\delta(\mathrm{ppm})$-109.04. HRMS: $\mathrm{m} / \mathrm{z}$ calcd for $\mathrm{C}_{17} \mathrm{H}_{12} \mathrm{O}_{5} \mathrm{NFSNa}(\mathrm{M}+\mathrm{Na}+)$, 384.0318, Found: 384.0322 $(\mathrm{M}+\mathrm{Na}+)$.

3-fluoro-5-((7-(methylsulfonyl)spiro[indene-1,2'-[1,3]dioxolan]-4-yl)oxy)benzonitrile (4).

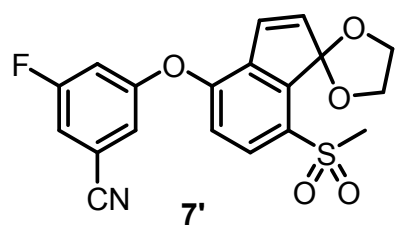

${ }^{1} \mathrm{H}$ NMR (500 MHz, $\left.\mathrm{CDCl}_{3}\right): \delta(\mathrm{ppm}) 7.84(\mathrm{~d}, J=8.7 \mathrm{~Hz}, 1 \mathrm{H}), 7.16$ (ddd, $J=7.6,2.0,1.2 \mathrm{~Hz}$, 1H), $7.10-7.07$ (m, 1H), 7.01 (d, $J=8.7 \mathrm{~Hz}, 1 \mathrm{H}), 6.97$ (dt, $J=9.3,2.3 \mathrm{~Hz}, 1 \mathrm{H}), 6.56$ (d, $J=6.0$ $\mathrm{Hz}, 1 \mathrm{H}), 6.27(\mathrm{~d}, J=6.0 \mathrm{~Hz}, 1 \mathrm{H}), 4.55-4.43(\mathrm{~m}, 2 \mathrm{H}), 4.21-4.12(\mathrm{~m}, 2 \mathrm{H}), 3.18(\mathrm{~s}, 3 \mathrm{H}) .{ }^{13} \mathrm{C}$ NMR $\left(126 \mathrm{MHz}, \mathrm{CDCl}_{3}\right): \delta(\mathrm{ppm}) 163.28(\mathrm{~d}, J=252.4 \mathrm{~Hz}), 158.20(\mathrm{~d}, J=11.0 \mathrm{~Hz}), 151.47,143.53$, 
136.82, 135.73, 134.53, 130.49, 125.63, $121.61,117.69$ (d, $J=3.6 \mathrm{~Hz}), 116.86$ (d, $J=3.6 \mathrm{~Hz})$, $115.72,114.98(\mathrm{~d}, J=11.5 \mathrm{~Hz}), 114.87(\mathrm{~d}, J=24.9 \mathrm{~Hz}), 111.05(\mathrm{~d}, J=24.6 \mathrm{~Hz}), 66.05,45.53 .{ }^{19} \mathrm{~F}$ NMR (471 MHz, $\mathrm{CDCl}_{3}$ ): $\delta$ (ppm) -105.94. HRMS: m/z calculated for $\mathrm{C}_{19} \mathrm{H}_{14} \mathrm{O}_{5} \mathrm{NFSH}:[\mathrm{M}+\mathrm{H}]^{+}$, 388.0655, found: $388.0649[\mathrm{M}+\mathrm{H}]^{+}$.

\section{R)-4-(3-(aminomethyl)-5-fluorophenoxy)-7-(methylsulfonyl)-2,3-dihydrospiro-[indene-1,2'- [1,3]dioxolan]-3-ol (2)}

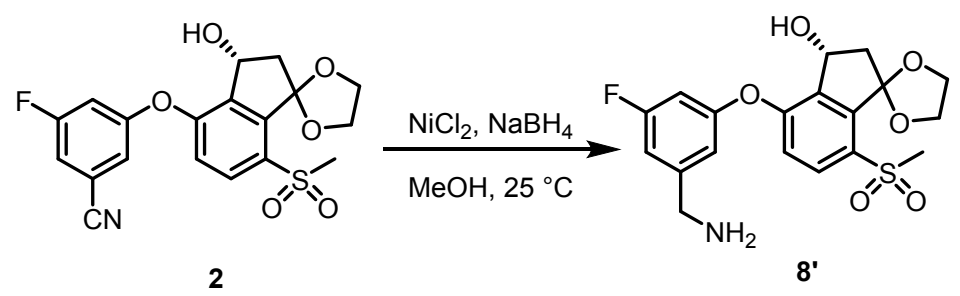

To a stirred solution of (R)-3-fluoro-5-((3-hydroxy-7-(methylsulfonyl)-2,3dihydrospiro[indene-1,2' -[1,3]-dioxolan]-4-yl)oxy)benzonitrile (2, $1.7 \mathrm{~g}, 4.19 \mathrm{mmol})$ in Methanol (135 mL) were added Nickel (II) Chloride $(1.09 \mathrm{~g}, 8.43 \mathrm{mmol})$ and sodium borohydride $(0.8 \mathrm{~g}$, $21.07 \mathrm{mmol}$ ) at $\mathrm{rt}$. After stirring the reaction mixture at $\mathrm{rt}$ for $22 \mathrm{~h}$, filtered the solids and filtrates was concentrated in vacuo to residue to provide the crude product. The crude product was purified on silica gel column (24.0 g, Gold) and Methanol and Ethyl acetate solvent system to give (R)-4(3-(aminomethyl)-5-fluorophenoxy)-7-(methylsulfonyl)-2,3-dihydrospiro-[indene-1,2'-

[1,3]dioxolan]-3-ol 8' as a white solid (1.5 g, Yield: 87\%). ${ }^{1} \mathrm{H}$ NMR (400 MHz, Methanol- $\left.d_{4}\right) \delta$ $8.03(\mathrm{~d}, J=8.6 \mathrm{~Hz}, 1 \mathrm{H}), 7.13-6.94(\mathrm{~m}, 3 \mathrm{H}), 6.86(\mathrm{~d}, J=9.5 \mathrm{~Hz}, 1 \mathrm{H}), 5.37$ (dd, $J=6.8,4.1 \mathrm{~Hz}$, $1 \mathrm{H}), 4.46-4.25(\mathrm{~m}, 2 \mathrm{H}), 4.24-4.05(\mathrm{~m}, 2 \mathrm{H}), 3.83(\mathrm{~s}, 2 \mathrm{H}), 3.29(\mathrm{~s}, 3 \mathrm{H}), 2.70(\mathrm{dd}, J=13.7,6.9$ $\mathrm{Hz}, 1 \mathrm{H}), 2.26(\mathrm{dd}, J=13.8,4.0 \mathrm{~Hz}, 1 \mathrm{H}).) .{ }^{13} \mathrm{C} \mathrm{NMR}\left(126 \mathrm{MHz}, \mathrm{CDCl}_{3}\right): \delta(\mathrm{ppm}) 163.28(\mathrm{~d}, J=$ $245.7 \mathrm{~Hz}), 158.50,156.1(\mathrm{~d}, J=16.4 \mathrm{~Hz}), 149.2$ (d, $J=7.6 \mathrm{~Hz}), 142.06,138.01,133.53,132.01$, 117.56, 115.30, $114.32(\mathrm{~d}, J=2.5 \mathrm{~Hz}), 110.10(\mathrm{~d}, J=22.7 \mathrm{~Hz}), 105.5$ (d, $J=25.2 \mathrm{~Hz}), 68.21$, $65.40,65.09,47.09,45.20,44.42$. 


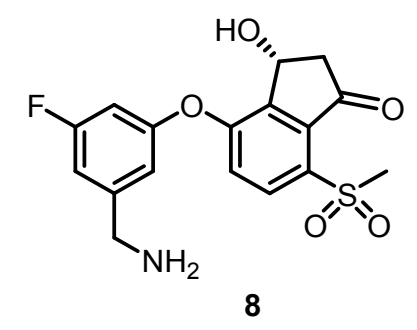

${ }^{1} \mathrm{H}$ NMR (400 MHz, $\left.\mathrm{D}_{2} \mathrm{O}\right) \delta 8.09-8.07(\mathrm{~d}, J=8.0 \mathrm{~Hz}, 1 \mathrm{H}), 7.32-7.30(\mathrm{~d}, J=8.0 \mathrm{~Hz}, 1 \mathrm{H}), 7.17$ $7.14(\mathrm{~d}, J=12.0 \mathrm{~Hz}, 1 \mathrm{H}), 7.10(\mathrm{~s}, 1 \mathrm{H}), 7.08-7.05(\mathrm{~m}, 1 \mathrm{H}), 5.66-5.63$ (dd, 1H), 4.19 (s, 2H), 3.45 (s, 3H), 3.34 - 3.28 (dd, 1H), 2.75 - $2.74(\mathrm{dd}, 1 \mathrm{H}) ;{ }^{13} \mathrm{C}$ NMR $\left(100 \mathrm{MHz}, \mathrm{D}_{2} \mathrm{O}\right) \delta$ 203.07, 164.57, 162.1, 159.6, 155.7, 146.9, 136.5, 135.3, 133.07, 129.3, 121.8, 116.52, 112.95, 108.65, 65.01, $46.19,42.22$.

(R)-3-fluoro-5-((3-hydroxy-7-(methylsulfonyl)-2,3-dihydrospiro[indene-1,2'-[1,3]dioxolan]4-yl)oxy)benzaldehyde

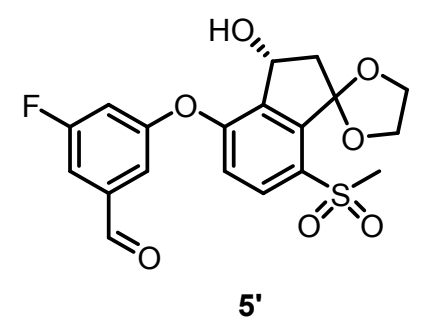

${ }^{1} \mathrm{H}$ NMR (400 MHz, CD 3 CN): $\delta(\mathrm{ppm}) 9.34-9.92(\mathrm{~m}, 1 \mathrm{H}), 7.99-7.97(\mathrm{~d}, J=8 \mathrm{~Hz}, 1 \mathrm{H}), 7.50-$ 7.47 (dd, 1H), 7.44 (s, 1H), 7.24- 7.21 (m, 1H), 7.21- 7.08 (m, 1H), 5.29-5.27 (m, 1H), 4.27- 4.25 (m, 2H), 4.07-4.03 (m, 2H), 3.59- 3.57 (d, $J=8 \mathrm{~Hz}, 1 \mathrm{H}), 3.22$ (s, 3H), 2.64- 2.60 (m, 1H), 2.13$2.12(\mathrm{~m}, 1 \mathrm{H}) .{ }^{13} \mathrm{C}$ NMR $\left(100 \mathrm{MHz}, \mathrm{CD}_{3} \mathrm{CN}\right): \delta \mathrm{ppm} 190.68,164.64,162.66,157.49,142.38$, 139.57, 138.70, 133.64, 133.09, 118.91, 116.22, 115.16, 112.90, 111.42, 68.21, 65.30, 47.19, 44.41. ${ }^{19} \mathrm{~F}$ NMR (376 MHz, $\left.\mathrm{CD}_{3} \mathrm{CN}\right): \delta(\mathrm{ppm})-110.37$. 
(R)-3-fluoro-5-((3-hydroxy-7-(methylsulfonyl)-1-oxo-2,3-dihydro-1H-inden-4-

yl)oxy)benzaldehyde

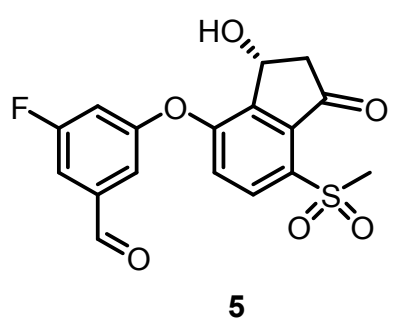

${ }^{1} \mathrm{H}$ NMR (400 MHZ, DMSO-d $\left.d_{6}\right) \delta 9.98-9.97(\mathrm{~d}, J=4,1 \mathrm{H}), 8.07$ - $8.04(\mathrm{~d}, J=12,1 \mathrm{H}), 7.64$ $7.62(\mathrm{~d}, J=8,1 \mathrm{H}), 7.52-7.50(\mathrm{~m}, 2 \mathrm{H}), 7.47$ - $7.45(\mathrm{~d}, J=4,1 \mathrm{H}), 5.39$ - $5.38(\mathrm{dd}, 1 \mathrm{H}), 3.43(\mathrm{~s}$, $3 \mathrm{H}), 3.24$ - $3.38(\mathrm{dd}, 1 \mathrm{H}), 2.60$ - $2.55(\mathrm{dd}, 1 \mathrm{H}) .{ }^{19} \mathrm{~F}$ NMR $\left(376 \mathrm{MHz}, \mathrm{DMSO}-d_{6}\right): \delta(\mathrm{ppm})$ 108.70 .

(R)-4-(3-fluoro-5-(hydroxymethyl)phenoxy)-7-(methylsulfonyl)-2,3-dihydrospiro[indene1,2'-[1,3]dioxolan]-3-ol

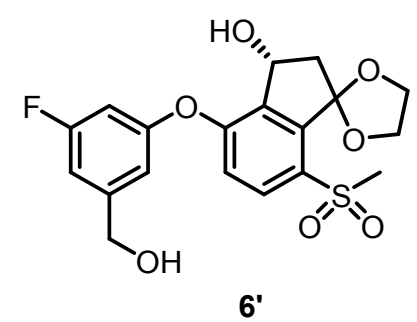

${ }^{1} \mathrm{H}$ NMR (500 MHz, $\left.\mathrm{CD}_{3} \mathrm{CN}\right): \delta(\mathrm{ppm}) 7.98-7.96(\mathrm{~d}, J=10 \mathrm{~Hz}, 1 \mathrm{H}), 6.95-7.02(\mathrm{~m}, 3 \mathrm{H}), 6.82-$ $6.85(\mathrm{~m}, 1 \mathrm{H}), 5.32(\mathrm{~s}, 1 \mathrm{H}), 4.60(\mathrm{~s}, 2 \mathrm{H}), 4.31-4.25(\mathrm{~m}, 2 \mathrm{H}), 4.07-4.03(\mathrm{~m}, 2 \mathrm{H}), 3.60(\mathrm{~s}, 1 \mathrm{H}), 3.42$ $(\mathrm{s}, 1 \mathrm{H}), 3.22(\mathrm{~s}, 3 \mathrm{H}), 2.64-2.60(\mathrm{~m}, 1 \mathrm{H}), 2.16-2.18(\mathrm{~m}, 1 \mathrm{H}) .{ }^{13} \mathrm{C} \mathrm{NMR}\left(126 \mathrm{MHz}, \mathrm{CD}_{3} \mathrm{CN}\right): \delta \mathrm{ppm}$ $163.1(\mathrm{~d}, \mathrm{~J}=245.7 \mathrm{~Hz}), 158.4,156.30$ (d, $\mathrm{J}=11.35 \mathrm{~Hz}), 147.0,142.09$, 138.07, 133.54, 132.11, 117.69, 115.28, 113.50, 109.30 (d, J = 21.40 Hz), 105.91 (d, J = 25.2 Hz), 68.22, 65.41, 65.09, 62.62, 47.09, 44.42. ${ }^{19} \mathrm{~F}$ NMR (471 MHz, $\left.\mathrm{CD}_{3} \mathrm{CN}\right): \delta(\mathrm{ppm})-112.40$. 
(R)-4-(3-fluoro-5-(hydroxymethyl)phenoxy)-3-hydroxy-7-(methylsulfonyl)-2,3-dihydro-1Hinden-1-one

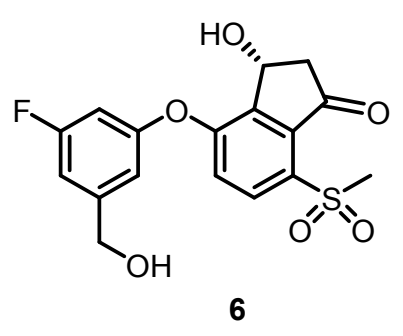

${ }^{1} \mathrm{H}$ NMR (400 MHz, $\left.\mathrm{CD}_{3} \mathrm{CN}\right): \delta(\mathrm{ppm}) 8.05-8.03(\mathrm{~d}, J=8.0 \mathrm{~Hz}, 1 \mathrm{H}), 7.21-7.19(\mathrm{~d}, J=8.0 \mathrm{~Hz}$, 1H), 7.04- $7.01(\mathrm{~d}, J=8.0 \mathrm{~Hz}, 1 \mathrm{H}), 6.98(\mathrm{~s}, 1 \mathrm{H}), 6.87-6.84(\mathrm{~m}, 1 \mathrm{H}), 5.54-5.50(\mathrm{~m}, 1 \mathrm{H}), 4.61-$ 4.59 (d, $J=8.0 \mathrm{~Hz}, 1 \mathrm{H}), 3.90-3.89$ (d, $J=4.0 \mathrm{~Hz}, 1 \mathrm{H}), 3.40-3.37$ (t, $J=12.0 \mathrm{~Hz}, 1 \mathrm{H}), 3.33$ (s, $3 \mathrm{H}), 3.18-3.13$ (dd, 1H), 2.67- 2.62 (dd, 1H). ${ }^{19} \mathrm{~F}$ NMR (376 MHz, $\left.\mathrm{CD}_{3} \mathrm{CN}\right): \delta$ (ppm) -112.19.

(R)-4-(3-fluoro-5-(((3-fluoro-5-(((R)-3-hydroxy-7-(methylsulfonyl)-2,3dihydrospiro[indene-1,2'-[1,3]dioxolan]-4-yl)oxy)benzyl)amino)methyl)phenoxy)-7(methylsulfonyl)-2,3-dihydrospiro[indene-1,2'-[1,3]dioxolan]-3-ol<smiles>CS(=O)(=O)c1ccc(Oc2cc(F)cc(CNCc3cc(F)cc(Oc4ccc(S(C)(=O)=O)c5c4C4(CC5O)OCCO4)c3)c2)c2c1C(O)CC21OCCO1</smiles>

${ }^{1} \mathrm{H}$ NMR (400 MHz, $\left.\mathrm{CD}_{3} \mathrm{CN}\right): \delta(\mathrm{ppm})$ 7.96-7.92 (m, 2H), 7.02- $6.95(\mathrm{~m}, 6 \mathrm{H}), 6.84-6.81(\mathrm{~m}, 2 \mathrm{H})$, 5.30- $5.27(\mathrm{dd}, 2 \mathrm{H}), 4.27$ - $4.24(\mathrm{~m}, 4 \mathrm{H}), 4.08$ - $4.04(\mathrm{~m}, 4 \mathrm{H}), 3.78(\mathrm{~s}, 4 \mathrm{H}), 3.57$ - $3.55(\mathrm{~d}, J=8.0$ $\mathrm{Hz}, 2 \mathrm{H}), 3.19(\mathrm{~s}, 6 \mathrm{H}), 2.63-2.56(\mathrm{dd}, 2 \mathrm{H}), 2.17-2.12(\mathrm{dd}, 2 \mathrm{H}) .{ }^{19} \mathrm{~F}$ NMR $\left(376 \mathrm{MHz}, \mathrm{CD}_{3} \mathrm{CN}\right)$ : 112.46 . 
(R)-4-(3-fluoro-5-(((3-fluoro-5-(((R)-3-hydroxy-7-(methylsulfonyl)-1-oxo-2,3-dihydro-1Hinden-4-yl)oxy)benzyl)amino)methyl)phenoxy)-3-hydroxy-7-(methylsulfonyl)-2,3-dihydro1H-inden-1-one

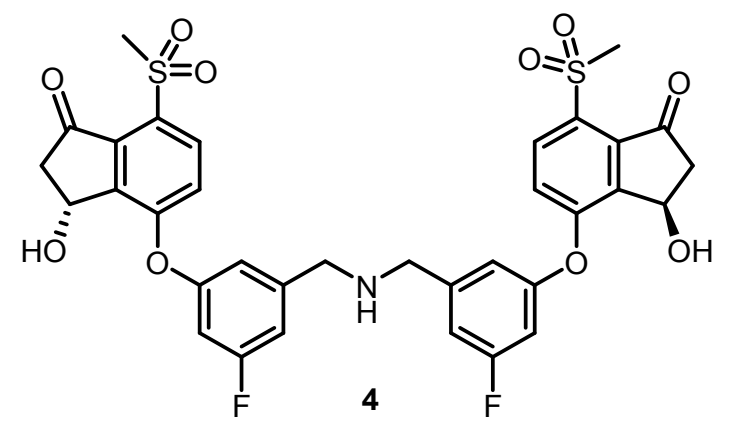

${ }^{1} \mathrm{H}$ NMR (500 MHz, $\left.\mathrm{CD}_{3} \mathrm{CN}\right): \delta(\mathrm{ppm}) 9.46$ (br s, 2H), 8.08- 8.06 (d, $\left.J=8.0 \mathrm{~Hz}, 2 \mathrm{H}\right), 7.40-7.38$ $(\mathrm{d}, J=8.0 \mathrm{~Hz}, 2 \mathrm{H}), 7.22-7.19$ (m, 4H), 6.98- 6.96 (br d, $J=8.0 \mathrm{~Hz}, 2 \mathrm{H}), 5.39-5.34$ (dd, 2H), 4.09- 4.06 (br t, $J=12 \mathrm{~Hz}, 4 \mathrm{H}), 3.33$ (s, $6 \mathrm{H}), 3.15-3.09$ (dd, $2 \mathrm{H}), 2.65-2.60$ (dd, $2 \mathrm{H}) .{ }^{13} \mathrm{C}$ NMR (126 MHz, $\left.\mathrm{CD}_{3} \mathrm{CN}\right): \delta$ (ppm) 200.64, 164.09, 162.13, 158.18, 157.49, 148.72, 136.11, 134.62, $132.81,132.27,124.15,113.22,107.60,65.04,49.81,46.89,42.60 .{ }^{19} \mathrm{~F} \mathrm{NMR}\left(471 \mathrm{MHz}, \mathrm{CD}_{3} \mathrm{CN}\right)$ : -111.12 . 


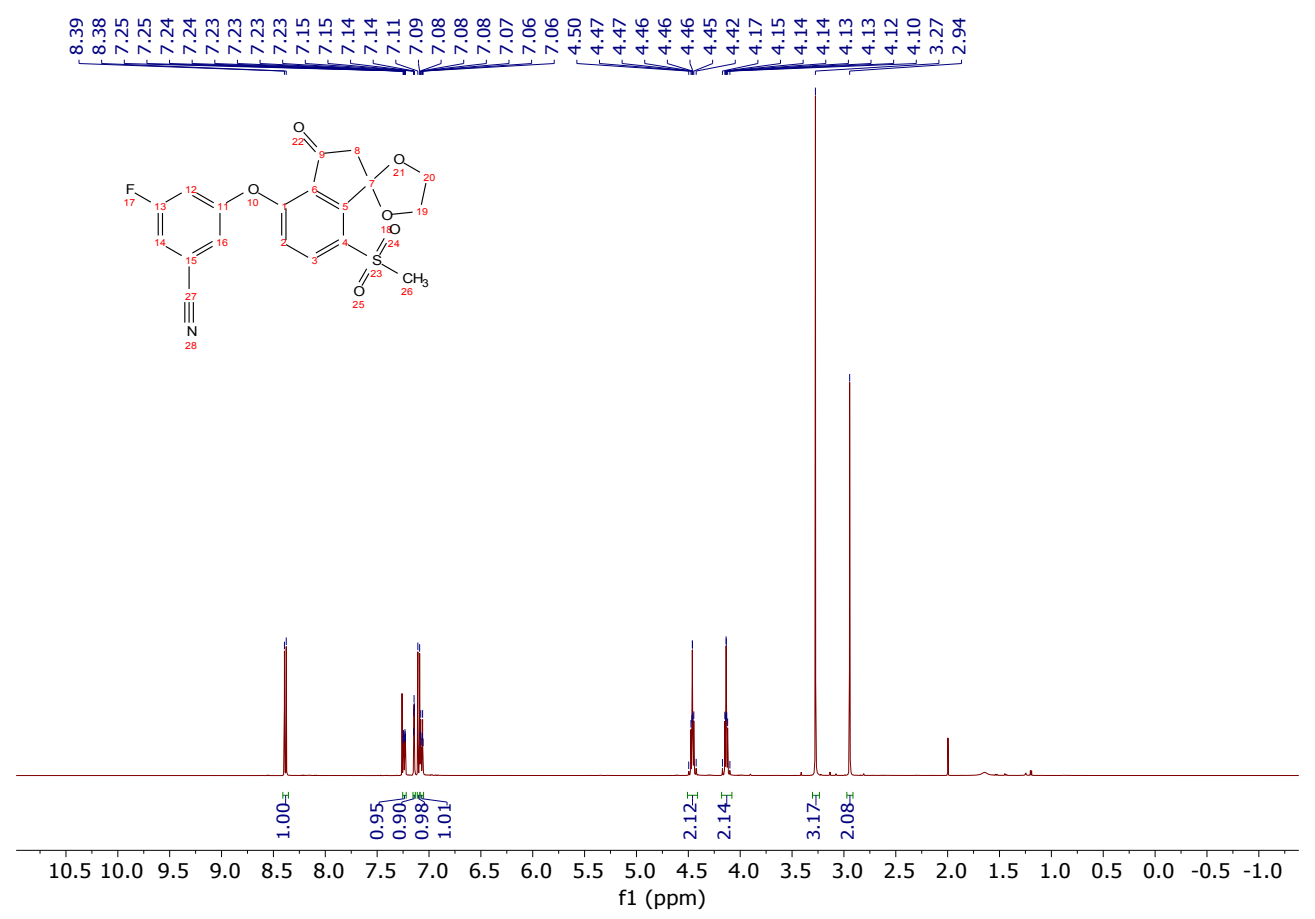

Figure S30. ${ }^{1} \mathrm{HNMR}$ data for compound $\mathbf{1}$.

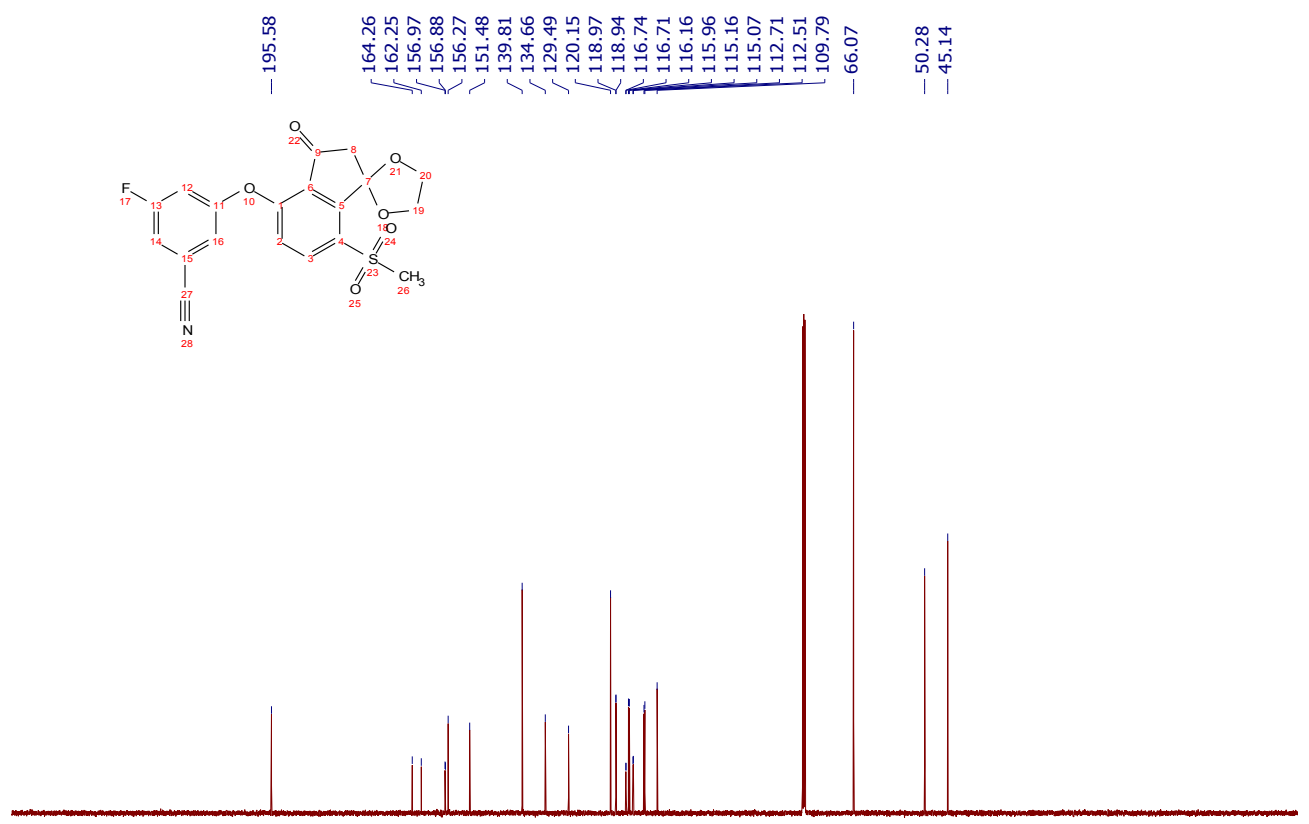

$25024023022021020019018017016015014013012011010090 \quad 80 \quad 70 \begin{array}{llllllllllll} & 50 & 40 & 30 & 20 & 10 & 0 & -10 & -20 & -31\end{array}$ f1 (ppm)

Figure S31. ${ }^{13} \mathrm{CNMR}$ data for compound 1. 


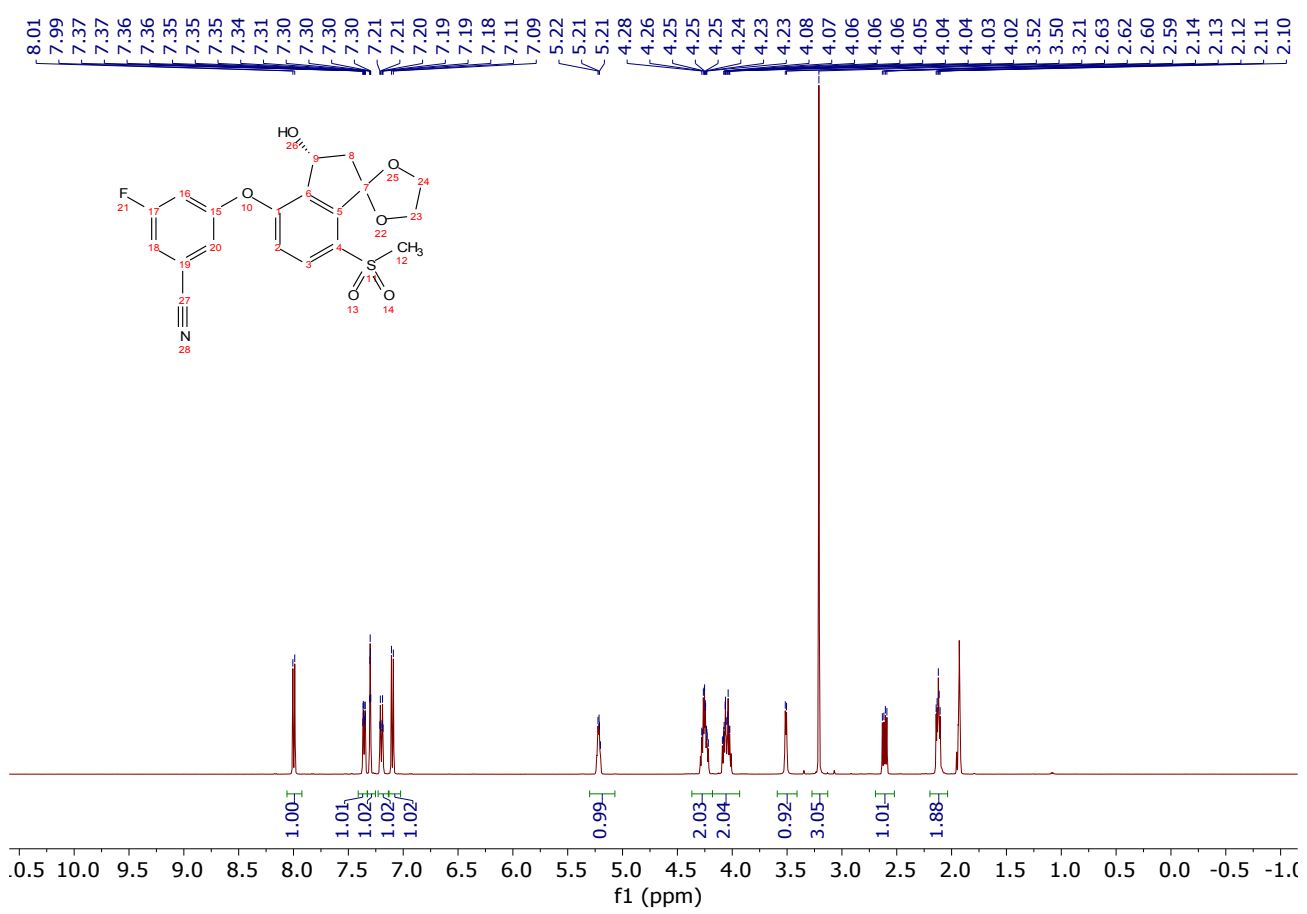

Figure S32. ${ }^{1} \mathrm{HNMR}$ data for compound 2.

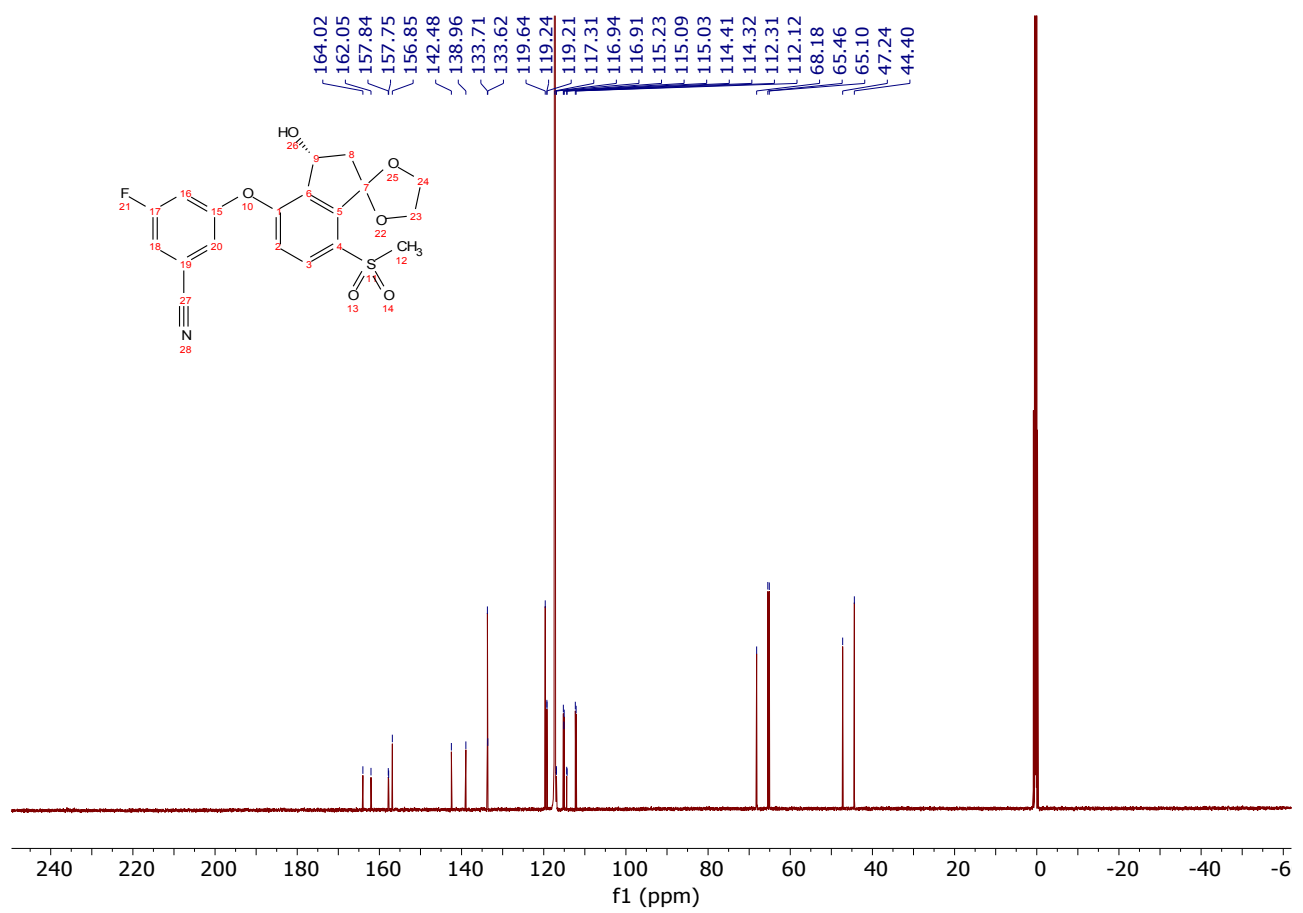

Figure S33. ${ }^{13} \mathrm{CNMR}$ data for compound 2. 


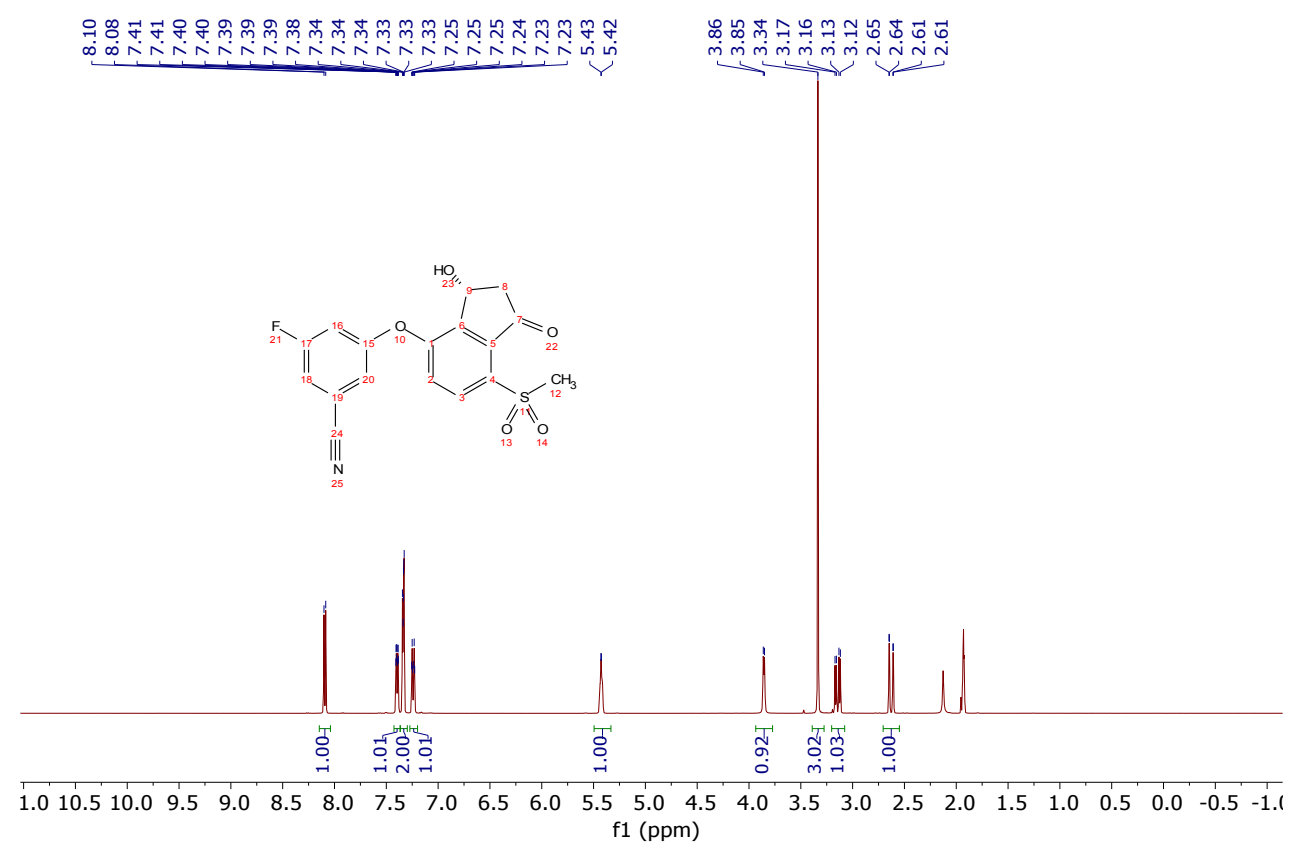

Figure S34. ${ }^{1} \mathrm{HNMR}$ data for compound 3.

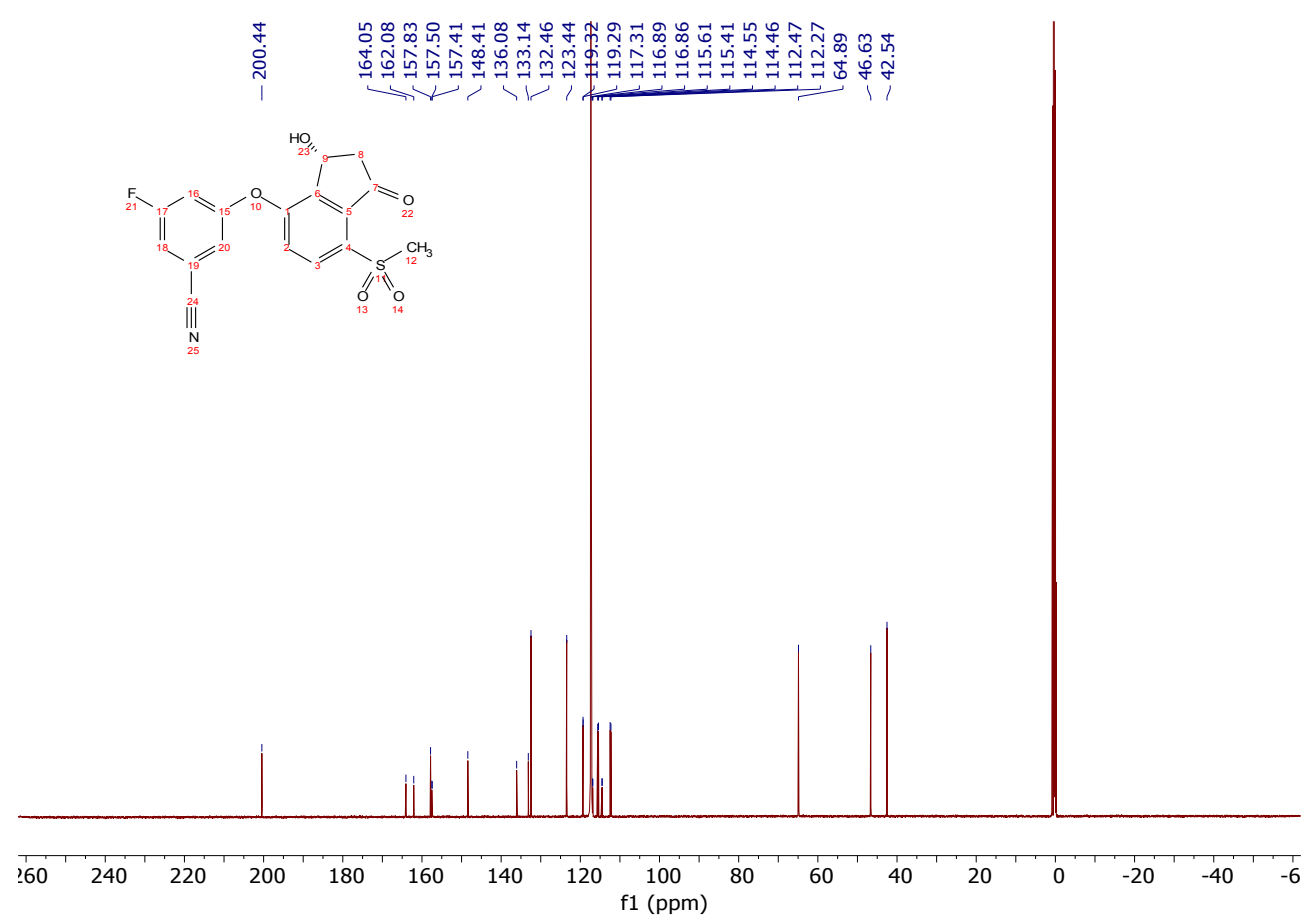

Figure S35. ${ }^{13} \mathrm{CNMR}$ data for compound 3 . 


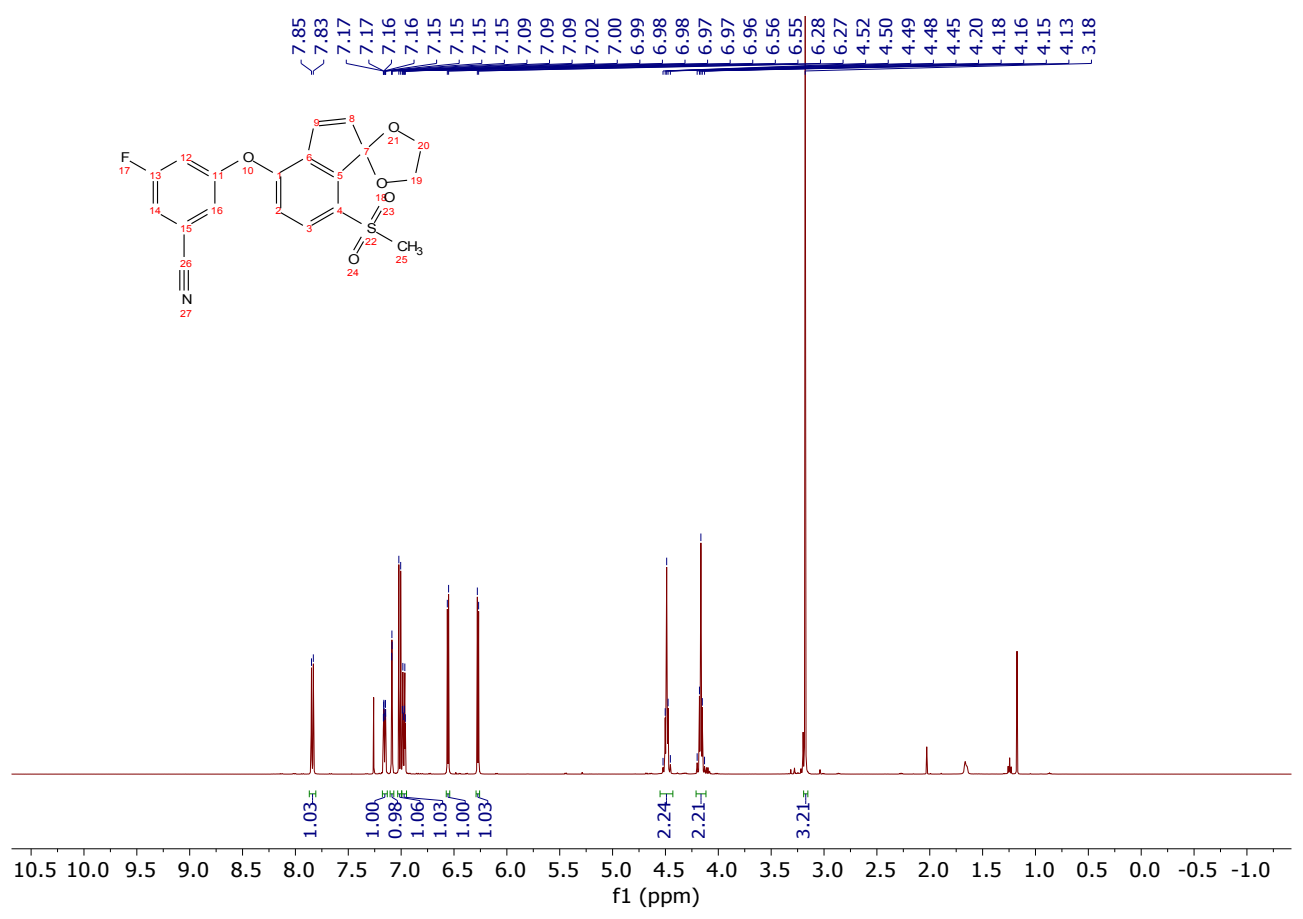

Figure S36. ' ${ }^{1} \mathrm{HNMR}$ data for compound 7'.

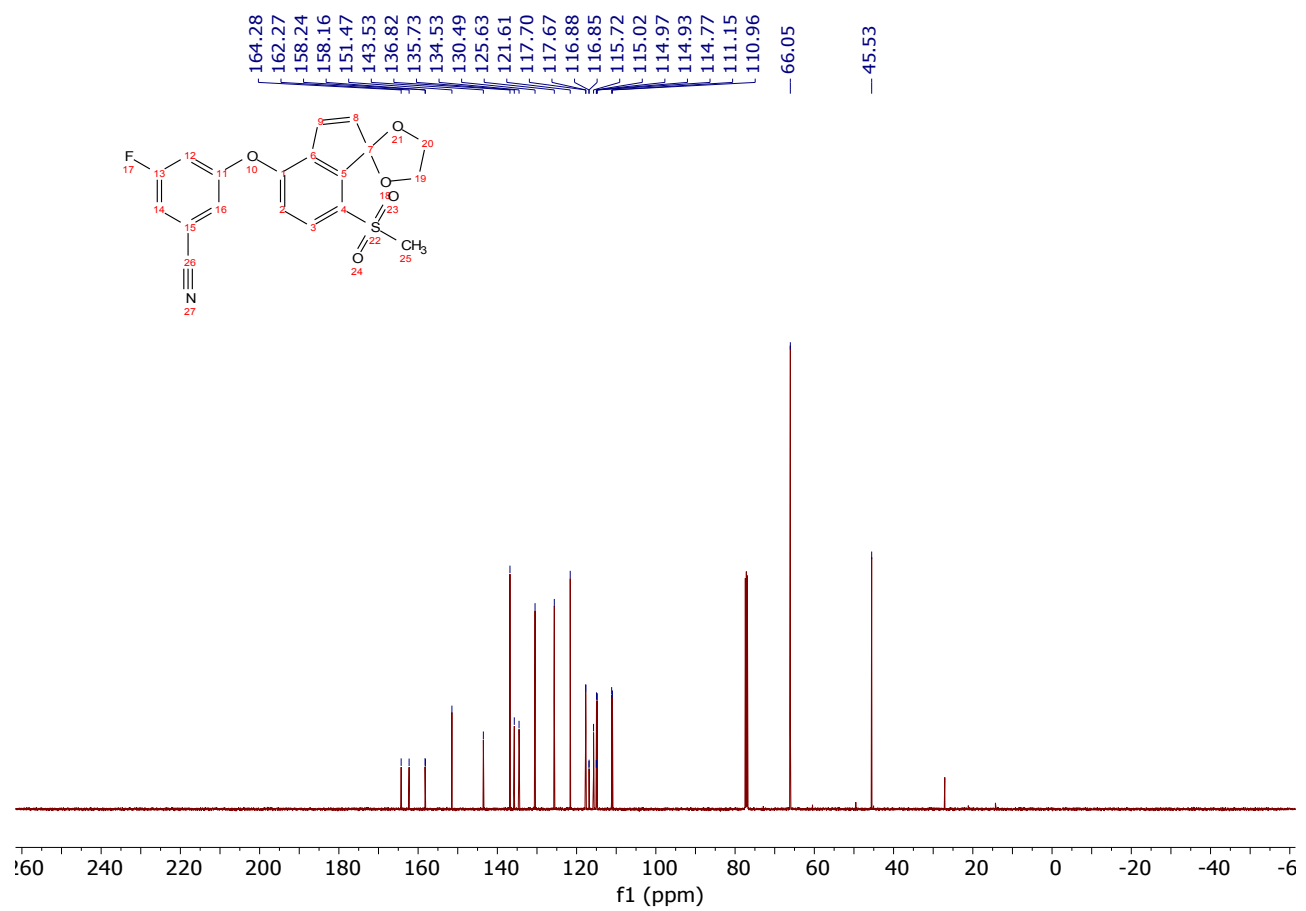

Figure S37. ${ }^{13} \mathrm{CNMR}$ data for compound 7'. 


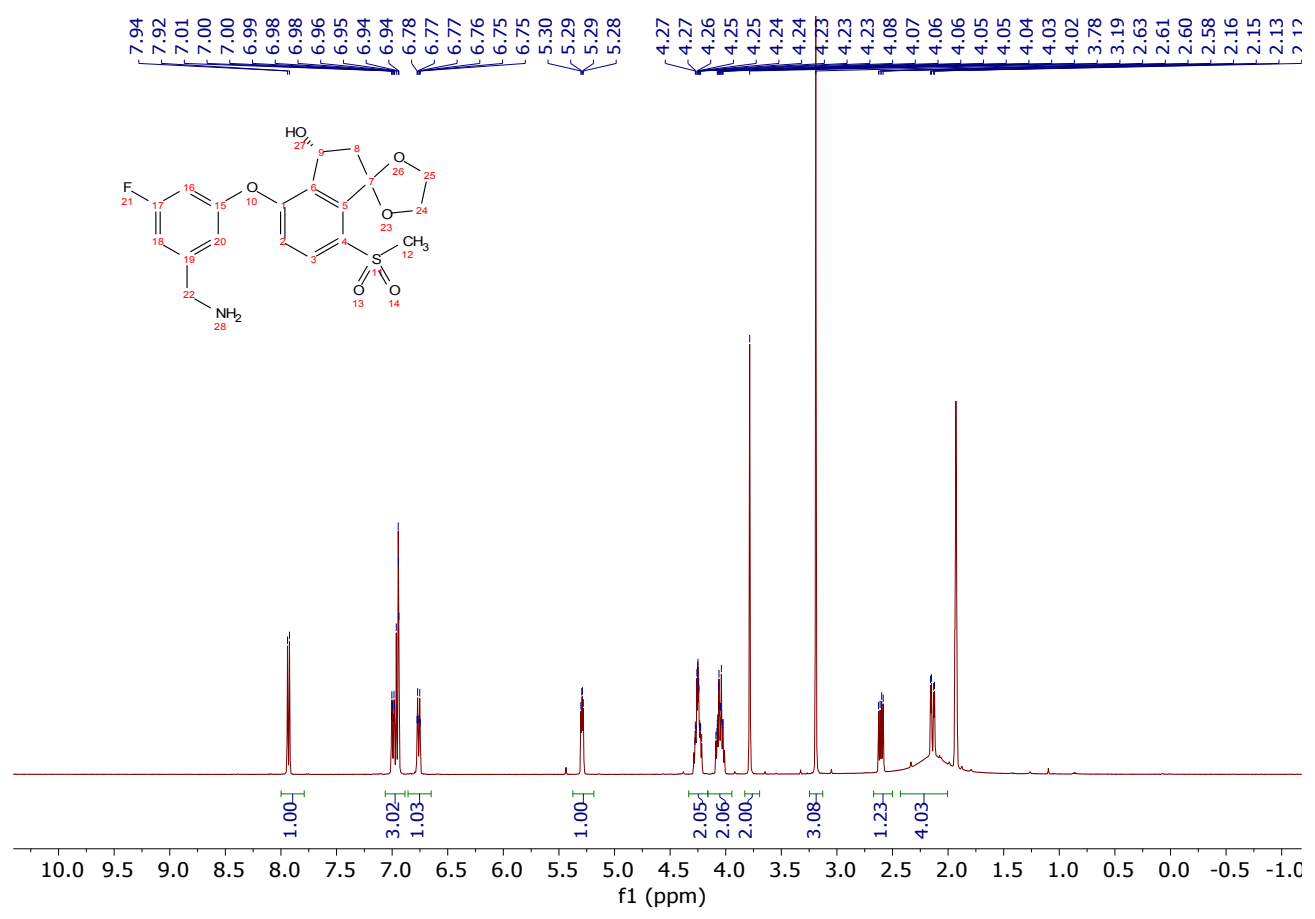

Figure S38. ${ }^{1} \mathrm{HNMR}$ data for compound $\mathbf{8}$ '.

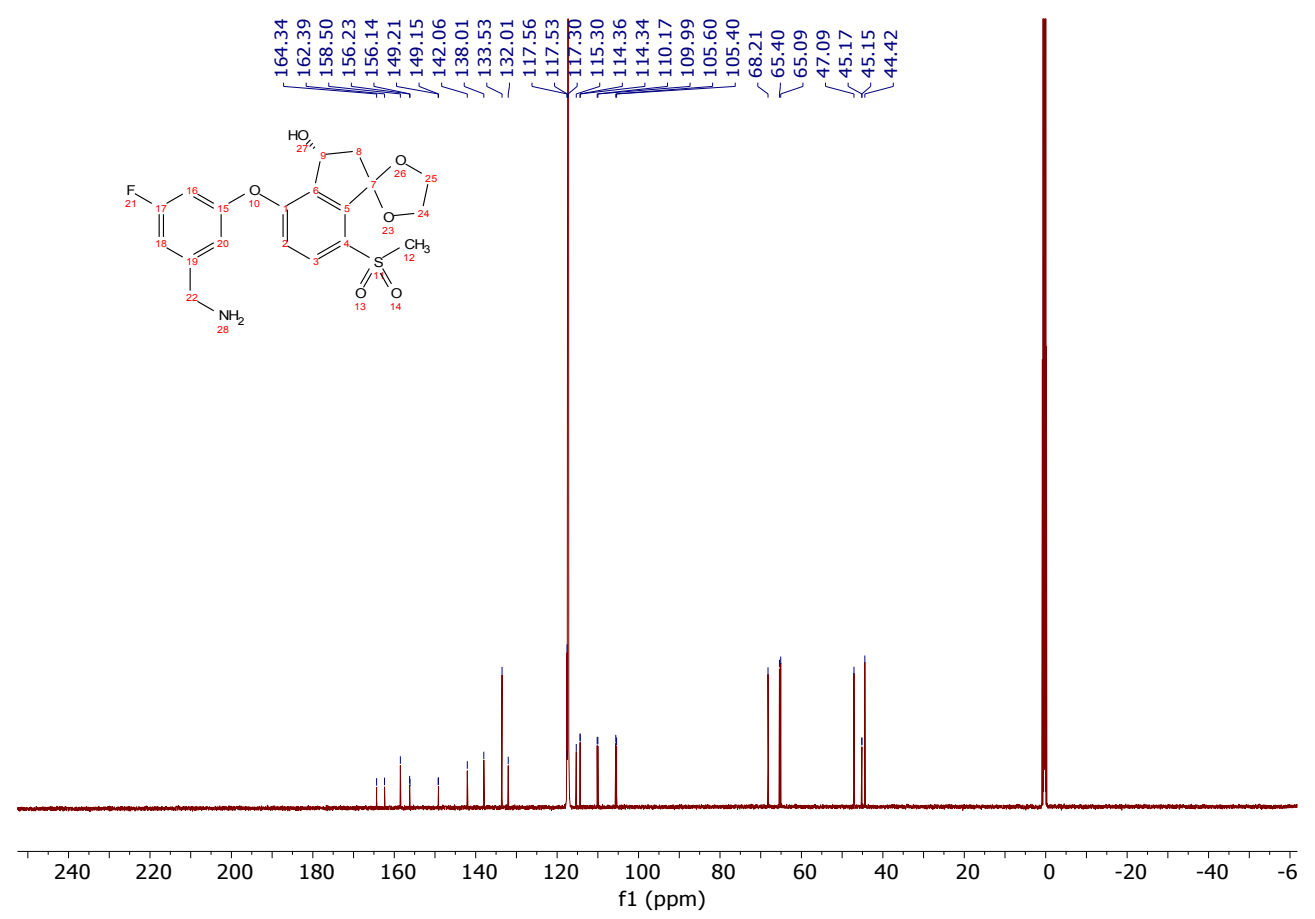

Figure S39. ${ }^{13} \mathrm{CNMR}$ data for compound $\mathbf{8}^{\prime}$. 


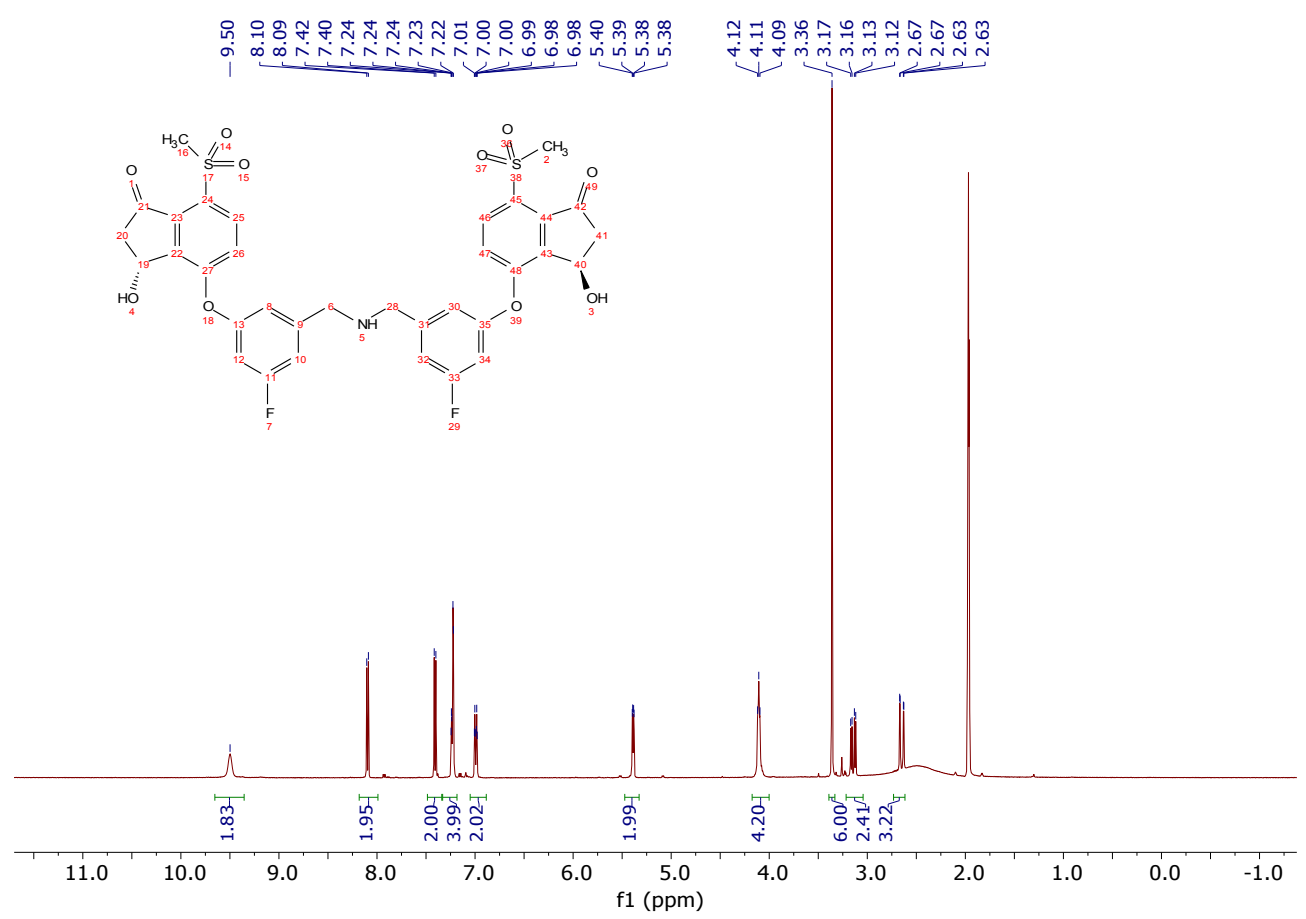

Figure S40. ${ }^{1} \mathrm{HNMR}$ data for compound 4.

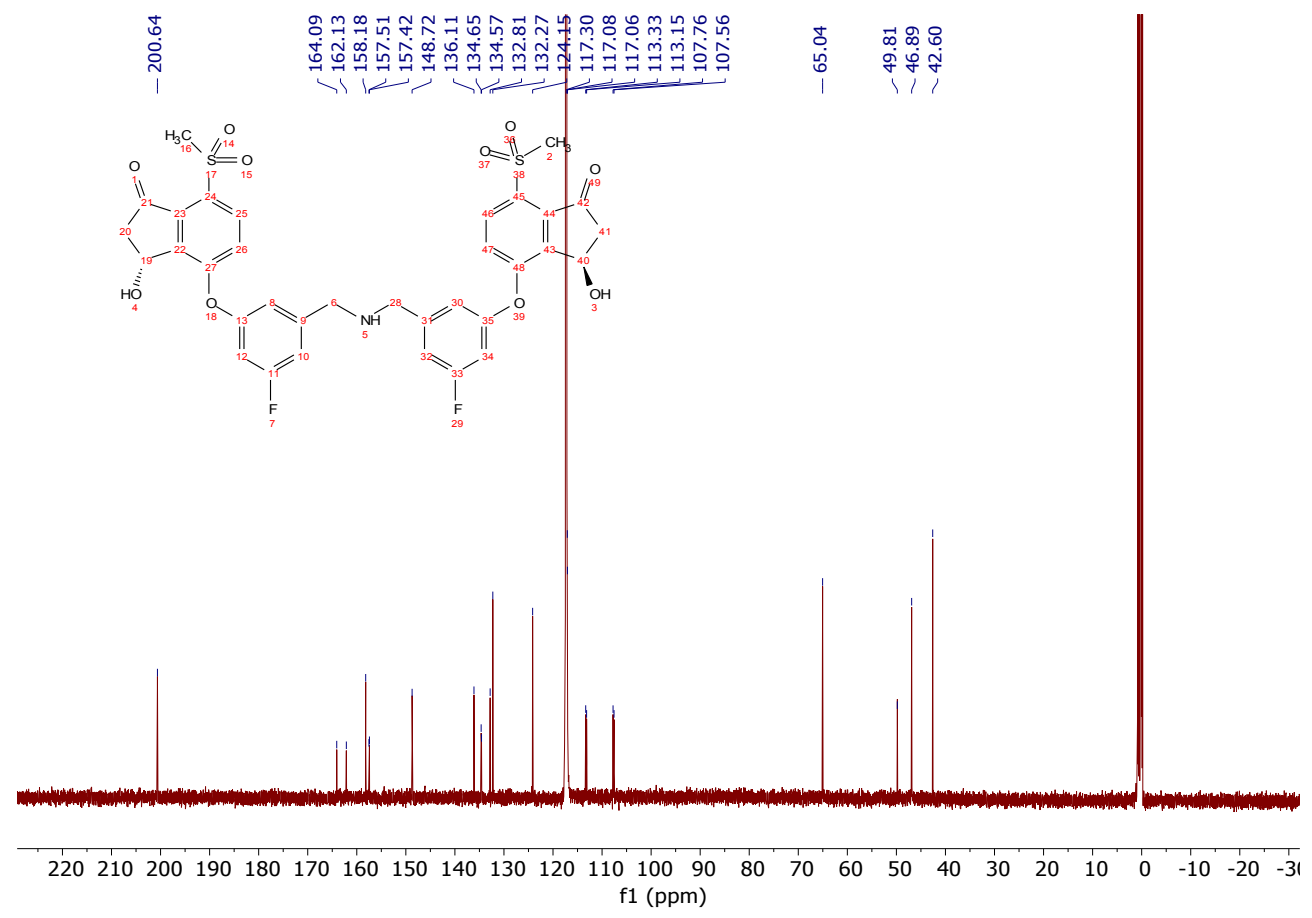

Figure S41. ${ }^{13} \mathrm{CNMR}$ data for compound 4. 

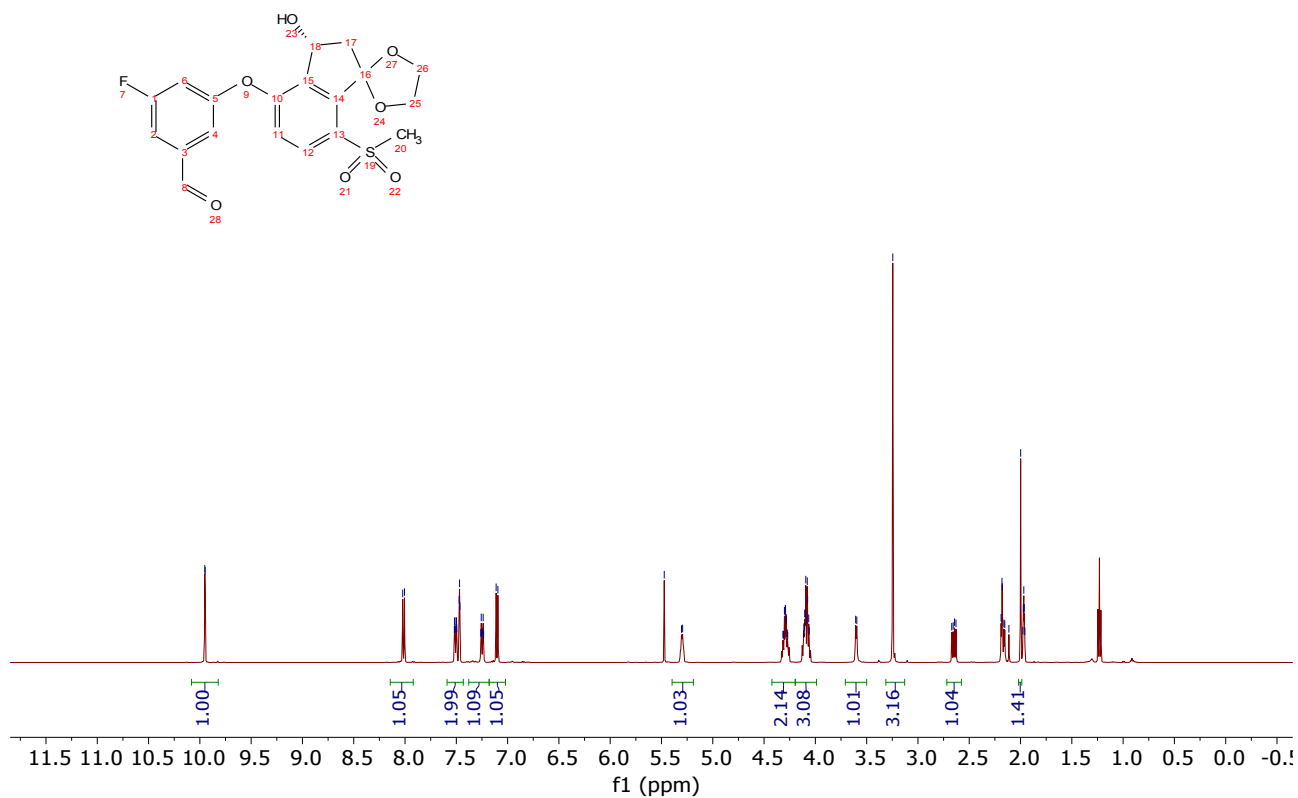

Figure S42. ${ }^{1} \mathrm{HNMR}$ data for compound $\mathbf{5}^{\mathbf{}}$.

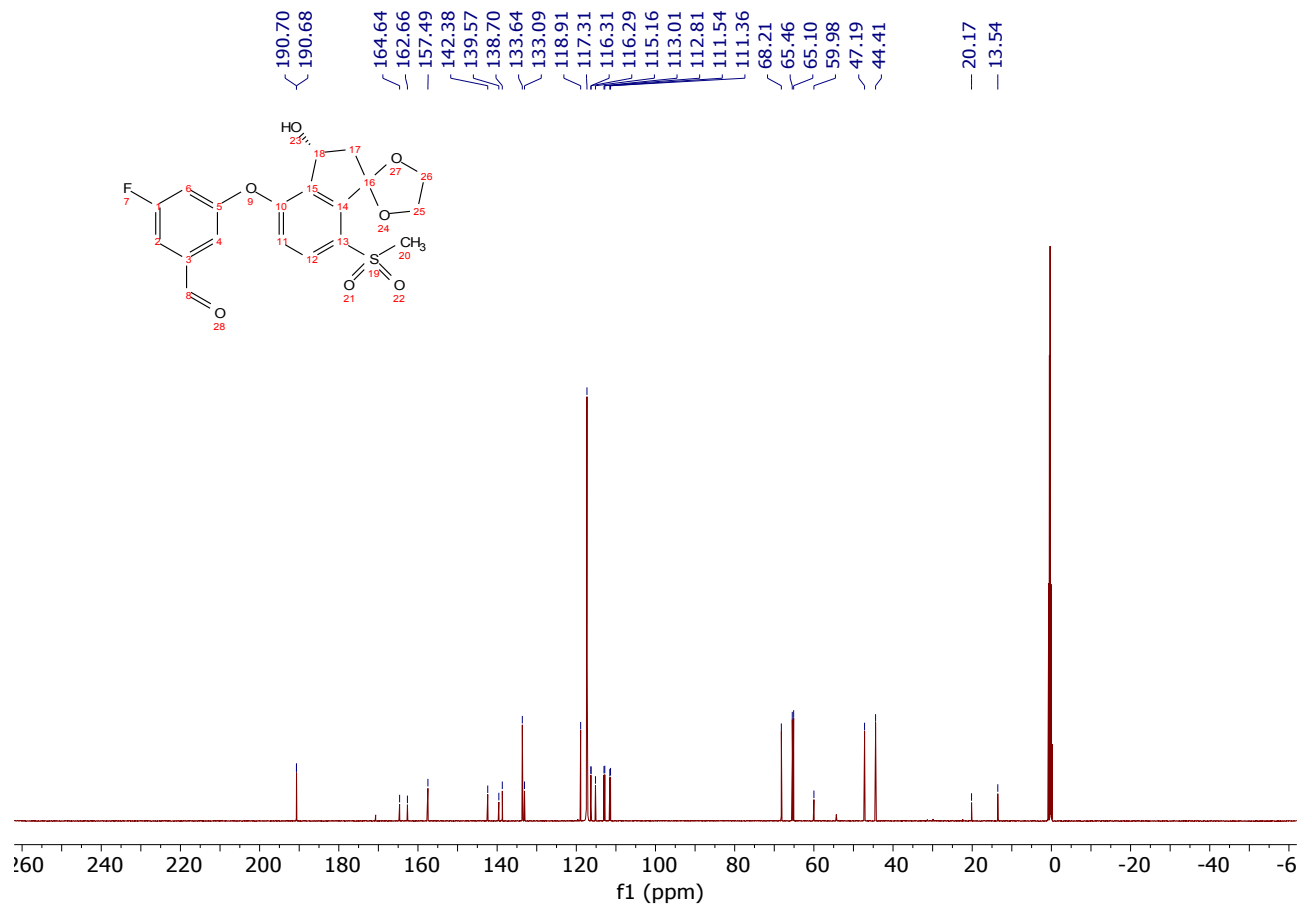

Figure S43. ${ }^{13} \mathrm{CNMR}$ data for compound $\mathbf{5}^{\prime}$. 

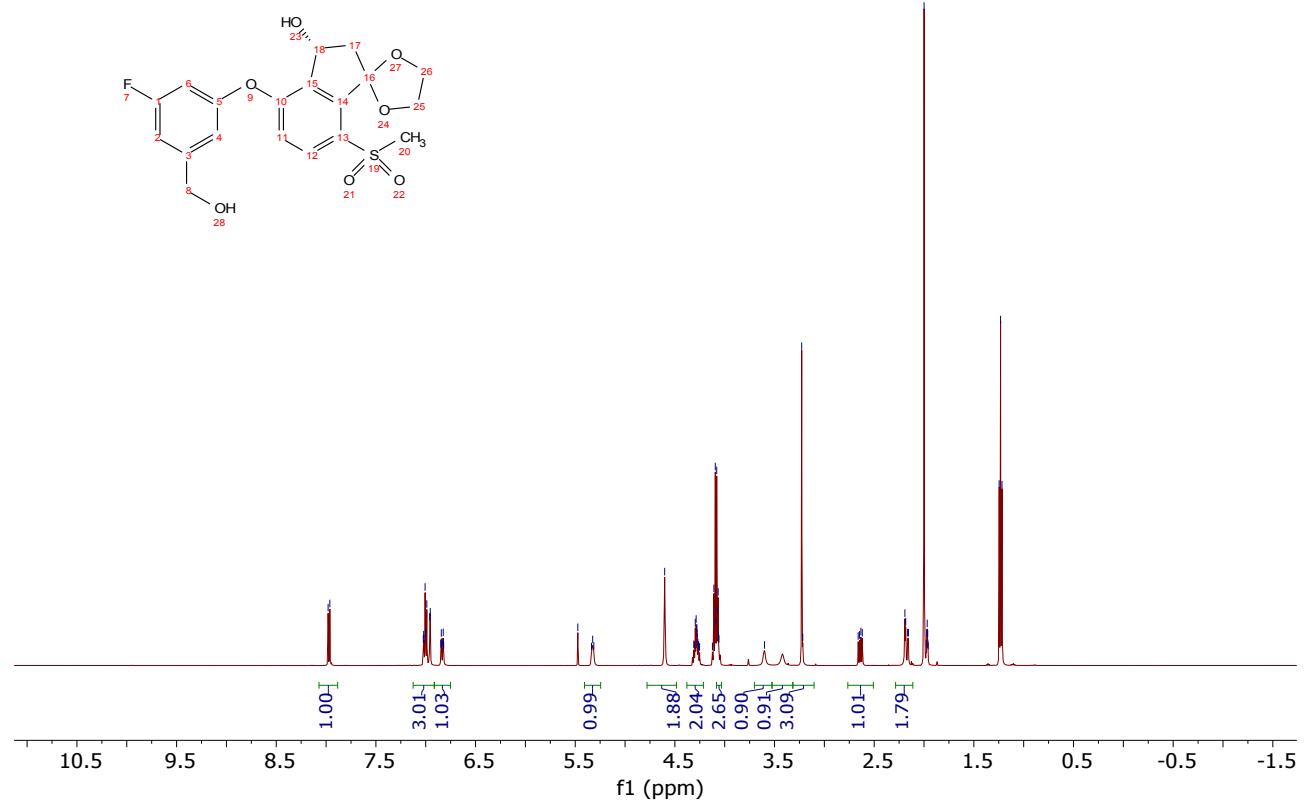

Figure S44. ${ }^{1} \mathrm{HNMR}$ data for compound 6'.

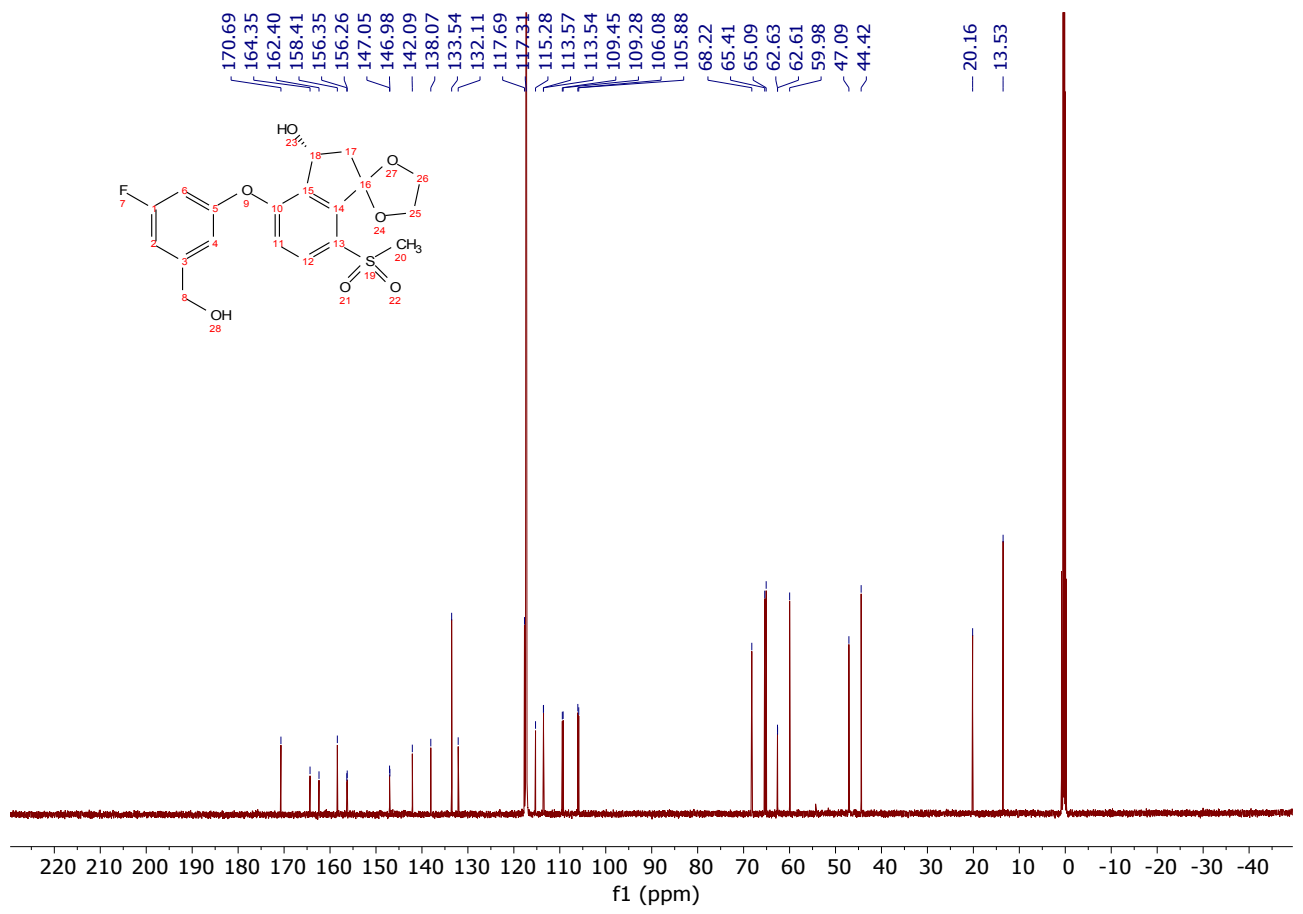

Figure S45. ${ }^{13} \mathrm{CNMR}$ data for compound 6 '. 